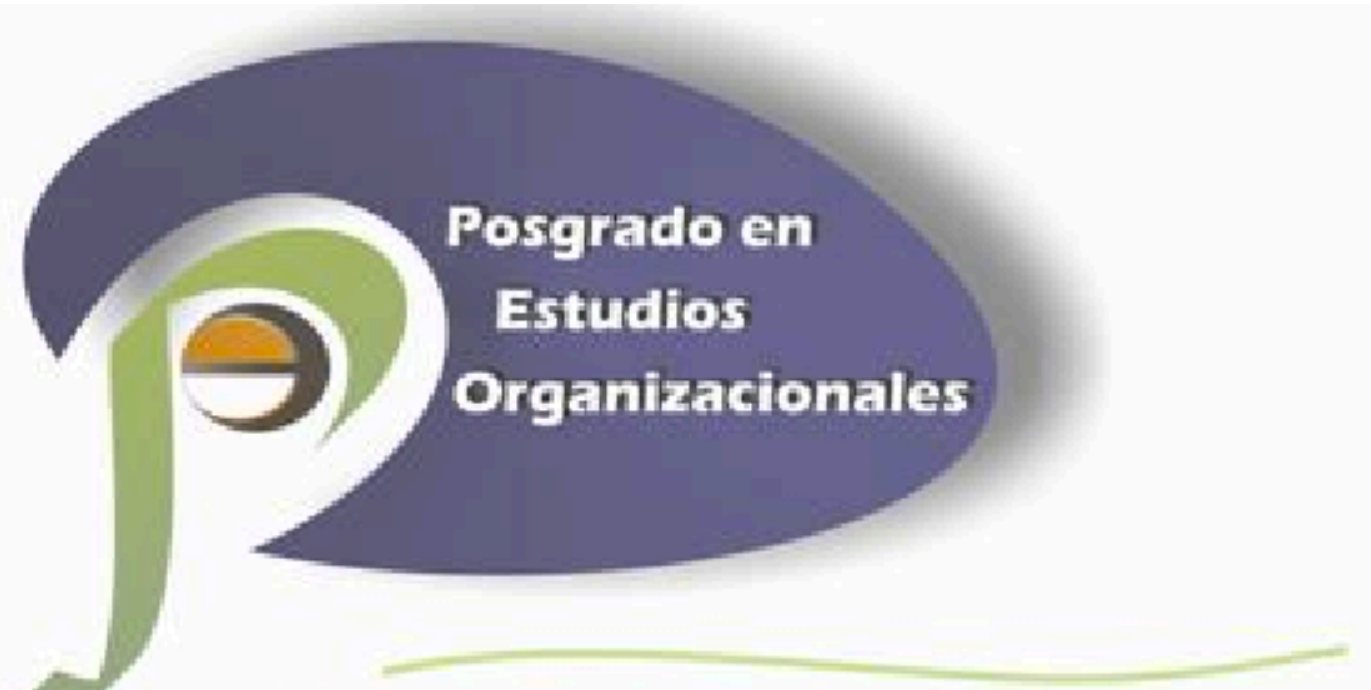

Adscrito al Padrón Nacional de Posgrados del Conacyt 


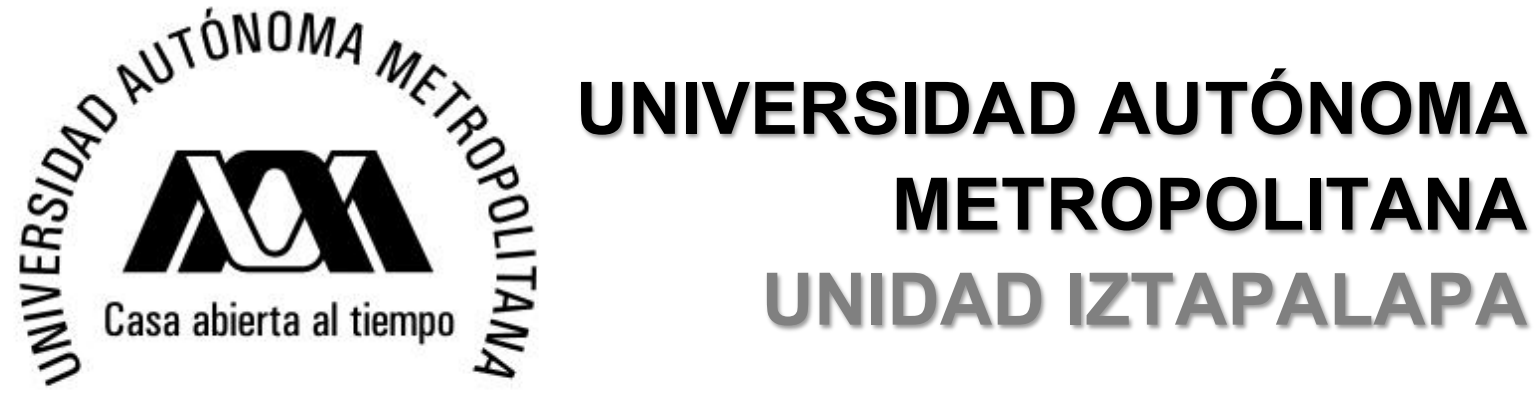

DIVISIÓN DE CIENCIAS SOCIALES Y HUMANIDADES

POSGRADO EN ESTUDIOS ORGANIZACIONALES

\section{ANÁLISIS DEL ESPACIO PERFORMATIVO EN UNA EMPRESA HOTELERA}

\section{TESIS}

\author{
Que para obtener el grado de \\ Maestro en Estudios Organizacionales \\ Presenta:
}

\section{MIGUEL ANGEL CASTILLO PÉREZ}

\author{
DIRECTOR DE TESIS \\ Dr. Adolfo Mir Araujo
}

MEXICO D.F.

2014 


\section{Agradezco por el apoyo incondicional a la familia, los amigos y el amor.}

Agradecimiento especial por su asesoría, tiempo y atención al Dr. Luis Montaño Hirose, cuya vocación a la docencia e investigación, inspiró y cimentó la confianza necesaria para publicar este trabajo.

Finalmente, a todos los pares de ojos y oídos que posaron su atención en este trabajo y le dieron forma con su franqueza y maestría: ¡Muchísimas gracias! 
A la Mtra. Renata
Solleiro Muñoz
(Ren) 


\section{ÍNDICE}

PRESENTACIÓN

i. JUSTIFICACIÓN

ii. INTRODUCCIÓN $r$

iii. LÍMITES Y ALCANCES

DISEÑO DE LA INVESTIGACIÓN 13

i. INSERCIÓN EN LOS ESTUDIOS 13

ORGANIZACIONALES

ii. LENTE PERFORMATIVA DEL ESPACIO $\quad 17$

iii. ASPECTOS METODOLÓGICOS $\quad 20$

CAPITULO 1. GENERALIDADES $\quad 29$

1.1 PRESENTACION DE LA ORGANIZACIÓN

1.2 CATEOGORIZACION DEL ESPACIO $\quad 39$

CAPITULO 2. TEMPORALIDAD $\quad 45$

2.1 TIEMPO Y TRANSITORIEDAD $\quad 46$

2.2 ESCENARIO FÍSICO $\quad \mathbf{5 4}$

2.3 CONTEXTUALIZACIÓN $\quad 63$

$\begin{array}{ll}2.4 \text { CONTINUIDAD } & 69\end{array}$

CAPITULO 3. PERFORMANCE $\quad 75$

3.1 ACONTECER DIARIO $\quad \mathbf{8 0}$

3.2 COMUNICACIÓN: HABLA Y ACCIONES $\quad \mathbf{8 7}$

3.3 JERARQUIZACIÓN DE ESPACIOS $\quad 102$

3.4 NTERACCION CON EL CUERPO HUMANO 116

$\begin{array}{ll}\text { CAPITULO 4. INTERPRETACIÓN DE LA REALIDAD } & 126\end{array}$

4.1 ESPACIO-TIEMPO $\quad 130$

4.2 VÍNCULOS Y REACCIONES

4.3 RELACIÓN CON LOS SENTIDOS, APEGOS, $\quad 150$

SENSACIONES Y AFECTOS

4.4 RECONOCIMIENTO DE LA MULTIPLICIDAD DE $\quad 167$

ESPACIOS

CAPITULO 5. DINAMISMO 173

5.1 DIRECCIÓN TRAYECTORIA

5.2 MOVIMIENTO E INTERACCIONES

5.3 ACOTACIÓN DE LA REALIDAD $\quad 189$

5.4 INTERACCIÓN ENTRE TODOS LOS ELEMENTOS 197

CONCLUSIONES $\quad 202$

EXTRACCIÓN: DIARIO DEL INVESTIGADOR 202

CONSIDERACIONES FINALES 205

$\begin{array}{ll}\text { BIBLIOGRAFIA } & 212\end{array}$ 


\section{PRESENTACIÓN}

"Y por segundos fuimos hermanos, familia, pueblo. Compartíamos sentimientos, miradas de sorpresa y risas nerviosas.

Después, todo igual. Había dejado de temblar. Volvíamos a ser desconocidos compartiendo un vagón del metro."

La presente investigación se inscribe dentro del programa de Maestría en Estudios Organizacionales, cuyo campo académico integral ha permitido en cierta medida justificar el carácter exploratorio de la forma y conceptos a tratar aquí. El origen y construcción del objeto de investigación remiten a un interés por atender la conceptualización del espacio como un elemento esencial en la participación de la sociedad.

\section{i. Justificación}

El 20 de marzo del 2012 un sismo de 7.8 grados en la Ciudad de México fue el detonante de una conversación sobre los momentos de crisis en la sociedad. ¿Qué se necesitaba para "despertar" a una población? Carlos Monsiváis (2005:9), publicó en "No sin nosotros": Los días del terremoto 1985-2005, sobre como el terremoto del '85 había dado paso a la organización de la población en un estado de mente inconcebible hasta ese momento: la sociedad civil. Los movimientos sociales suscitados antes del '85 habían sido el sustento que maduraba a una población necesitada de voz. El uso de esta voz, deja entrever Monsiváis, más allá del momento de crisis, tiene una relación con el sentimiento 
de apropiación del espacio público. ¿De dónde nace este sentimiento?, ¿qué características ofrece o se busca en un espacio, para poder sentirse parte de éste?, ¿cómo el espacio incide en la organización de la gente?, y ¿cómo dota el espacio de una voz?

La idea sobre el espacio como elemento inherente en la construcción de un ciudadano con voz, encausó interés en conceptos como el anonimato, el transeúnte, el espacio privado, personal y público, el ocio y el empoderamiento a partir del conocimiento. Pero, ¿qué relación tiene con los Estudios Organizacionales?

Más allá de limitar, las líneas de investigación de este posgrado han permitido acotar el paisaje ideario. La propuesta inicial de un espacio público ${ }^{1}$ dentro de la organización, como construcción inherente del actuar de los trabajadores a partir de los vacíos legales de la empresa -es decir, un lugar dentro de la empresa, externo a lo estrictamente laboral, que dotaba de poder al trabajador para permitirse actuar fuera de su rol como empleado y con ello, promovía el desarrollo de la propia organización-, exigía en primer instancia, la conceptualización de una parte esencial: el espacio.

Se habla del espacio como un área física, un momento, un sinónimo del universo, un hueco, aquello que separa dos entidades o una delimitación; el cúmulo de acepciones complejizan la capacidad de comprender a qué nos referimos cuando hablamos del espacio. ¿Cómo tratar la conceptualización del espacio público, sin tratar antes la conceptualización del espacio en sí?

${ }^{1}$ cfr. Si bien, bajo la misma línea que este trabajo, Rabotnikof (2005) hace énfasis en el interés por profundizar en las 
Su enunciación era substancial para la investigación, pero exigía una segunda investigación: el presente trabajo.

\section{ii. Introducción}

Proponer un análisis del espacio dentro de una organización, y específicamente en el campo de los estudios organizacionales, nos conduce al concepto de Spacing Organization (Beyes y Steyaert, 2011), que presenta de manera teórica un planteamiento más ecléctico sobre la percepción del espacio en el análisis organizacional. En el presente trabajo se explora con esta concepción del espacio. A través de la interpretación de los autores, se propone una categorización de los elementos principales del Spacing que pueden ser observados en una organización, para observar su pertinencia y alcance en un estudio de caso; y se empata con una metodología que se apetece pertinente y afín con la visión propuesta por los mismos autores. Ante todo, la pregunta inicial es: ¿Cómo analizar el spacing en una empresa?

Así, sin quitar el dedo del renglón de lo planteado en el apartado anterior, la tesis es una primera parte, de un interés particular por profundizar en el concepto de espacio en el análisis organizacional, y alejarlo de una concepción absoluta sinónima de lugar. El enfoque de este trabajo ve al espacio más allá de un área física, como la incorporación de distintos elementos en el actuar diario de las personas (Beyes y Steyaert, 2011:49). Es decir, se plantea que el espacio desde un concepto performativo, no sólo es referente físico, sino resultado de la misma 
dinámica del comportamiento de los individuos que lo forman: roles, precepciones, referentes, historia de vida, entorno y objetivos.

Y si la sociedad y la empresa mantienen una diferente concepción en cuanto al objetivo de organizarse, la percepción que se tiene sobre el espacio dentro de una empresa, por ende tendería a ser distinta. ¿Cómo viven el espacio de una organización, los trabajadores de ésta?

Para cuestiones de este trabajo en particular, la organización es vista como un sinónimo de empresa, por el interés de trabajar el tema en una organización privada. La selección de la organización no ha sido un resultado aleatorio. Por el contrario, otro punto de énfasis de la investigación es el lugar físico de análisis. La empresa pertenece al ramo hotelero, un tipo de organización poco tratado en el campo académico fuera de disciplinas como la Administración de Empresas, la Mercadotecnia, y la Hotelería y Turismo. Sin embargo, este giro -de servicioen particular, permite la observación más evidente, de la manera en que se vive una misma área física bajo lógicas contrastantes, por los mismos trabajadores. Un hotel es una empresa de servicio, cuyos empleados mantienen una relación constante y paralela con diversos públicos: huéspedes, compañeros de trabajo, jefes directos y alta gerencia, entre otros. Los recursos utilizados del trabajador no son los mismos al performar frente a un huésped que a un supervisor, y $\sin$ embargo se debe realizar de manera simultánea. Si la incorporación de distintos elementos en el actuar diario del trabajador -las actividades, los roles, los apegos, las sensaciones- son diferentes en ambos casos, ¿el espacio es igual? 
¿Es el mismo espacio, si se trata de una misma área física pero no de una misma percepción de ésta? ¿Puede haber más de un solo espacio? La teoría del Spacing Organization (Beyes y Steyaert, 2011) trabajada en el análisis organizacional profundiza en este fenómeno, y presenta una manera diferente de leer al espacio, no como un fenómeno que se construye sino que se performa. La diferencia de este término converge en el planteamiento de la incorporación como parte del espacio -no visto sólo como un área física- y a su vez despliega otra serie de elementos a trabajar en la exploración del concepto dentro del hotel, como lo es la multiplicidad de espacios, la trayectoria, el ritmo, el contexto, los sentidos, la interacción con el cuerpo humano, entre otros. El Spacing Organization, a su vez, no sólo señala una lente distinta sobre un fenómeno, sino una metodología diferente para abordarse. Se está tratando con conceptos performativos ${ }^{2}$, y su uso promueve una visión más dinámica y de diálogo en la propia elaboración del proyecto de investigación. De ahí que se haga uso de la narrativa, como soporte metodológico, para enfatizar en la simultaneidad con que se reinterpreta a la organización -y por ende al espacio-, por parte de los trabajadores. La temporalidad no es el único elemento que esta metodología permite abordar con mayor naturalidad, pues paralelamente se resalta la subjetividad de los trabajadores, al presentar sus voces entretejidas con las observaciones del narrador (el investigador) y los aportes teóricos que dotan de formalidad académica al presente trabajo.

\footnotetext{
2 Markovska (2008) profundiza en el concepto de performative para proponer una lente diferente a los conceptos absolutos que se manejan dentro de la investigación, donde lo performativo es la acción misma del ser y se enfoca en la conciencia de la acción (lo encarnado).
} 


\section{iii. Límites y Alcances}

El trabajo es resultado de un diálogo constante entre la teoría y la práctica. El proceso de la investigación remitía a un ajuste persistente de los supuestos básicos que se tratan dentro del marco teórico. Tal dinámica se dio a partir de la forma en que se suscitó la inserción en el campo de trabajo. El hotel fue seleccionado por la apertura dada para la recolección de datos, sin necesidad de cubrir un horario o actividades específicas que resultaran un beneficio económico o de calidad de servicio directo e inmediato para éste. El apoyo de la alta gerencia fue un cobijo esencial para concretar el proyecto de investigación. La información obtenida, bajo este continuo soporte de la Dirección General, permitió redireccionar las directrices del trabajo conforme lo iba requiriendo la propia investigación, sin impedimento alguno. La misma etapa inicial en la que se encontraba la empresa, dotaba de un ambiente más accesible y poco celoso para la recolección de datos, bajo el supuesto que todo lo observado podía ser factible de mejora y cualquier opinión externa sería de mucha ayuda para alcanzar los resultados más benéficos para la organización. Paralelamente, los obstáculos inherentes a la sensación de ser evaluados o juzgados por un tercero, seguían haciendo difícil este proceso de recolección de datos. Pero, no más de lo que podría suponerse de cualquier otra empresa. En un principio se planteó nutrir el trabajo con un análisis fotográfico que diera cuenta de manera más explícita y visual, el lenguaje corporal y la dinámica de las interacciones. Sin embargo, la presencia de un dispositivo fotográfico situaba en estado de alerta a los trabajadores, temerosos de ser evidenciados frente a un público ajeno. Tal 
situación limitó el uso de una cámara pero permitió profundizar en el fenómeno de la percepción de autoridad y el doble discurso del trabajo en hotelería: trabajo altamente exigente y fatigoso VS apropiación del rol y administración del tiempo personal. "En un hotel se trabaja a marcha pesada, aunque siempre hay tiempo para darse un descanso bien merecido" (Trabajador3, comunicación personal, 27 de mayo 2013).

Por ello, se enfatiza el uso del análisis narrativo, como metodología, para exaltar el detalle de las sensaciones y la observación. El tiempo ha sido un elemento crucial, puesto que aún siendo un estudio de caso, la observación y recolección de datos se dio en un periodo corto no mayor a tres meses, lo cual limita la capacidad de contrastar las dinámicas en distintas temporadas -baja y alta- de la actividad hotelera, pero no así de identificar las reapropiaciones semánticas que se van dando en la jornada diaria. Igualmente, una jornada laboral en el hotel va sufriendo de rotación de turnos, sin embargo, el turno nocturno no fue observado de manera directa, mas bien referido por lo comentado en las entrevistas realizadas, por la logística que ello requería.

Finalmente, se reitera el enfoque exploratorio de esta investigación, proponiéndose una expectativa de alcance media, en lo que se refiere a la conceptualización misma del objeto de estudio. Es decir, se busca hacer énfasis en la necesidad de una concepción menos absoluta del espacio; por lo cual, a su vez, se reconoce la presencia de otros elementos de análisis dentro del espacio, que han sido dejados de lado por la necesidad de acotar el trabajo en un primer acercamiento, bajo este enfoque y a partir de la metodología seleccionada. 


\section{DISEÑO DE LA INVESTIGACIÓN}

\section{i. Inserción en los Estudios Organizacionales}

Los Estudios Organizacionales suponen que cada organización responde a un conjunto particular de elementos que la visten y conforman. Es en el análisis de estas particularidades que se sitúa la comprensión del gran paisaje organizacional con el que cuenta un sector, región o país.

El análisis del espacio performativo en una empresa hotelera se puede situar bajo este enfoque diferente, cuyo auge se presentó en los ochentas; donde la empresa deja de ser vista tan sólo como un ente económico y racional. Los países industrializados abordan a la empresa como una organización abstracta, cúmulo de símbolos que son causa de las particularidades de cada empresa. De acuerdo con Smircich (1983) esta entidad inmaterial, se percibe como un universo de formas que logran mantener un control sobre los empleados a partir de un sistema de símbolos y de significaciones llamado cultura.

Si bien la cultura ya ha sido estudiada desde la antropología, en los estudios organizacionales, el concepto de cultura, de acuerdo con Smircich (1983), se aborda desde dos lentes de análisis: metáfora y variable.

Un gran número de trabajos escolares sobre hotelería, están ubicados en el enfoque de la cultura como variable, pues es vista como elemento que una organización posee, es decir, la cultura organizacional de los hoteles. En su estudio, esta lente generalmente refiere a un objetivo de practicidad o mejora alineada a los fines de la empresa. Pero vista como metáfora, la cultura pretende 
ver a la organización como una cultura en sí. Esta lente -perspectiva cognitiva según Smircich (1983)- evita encapsularse en cualquier sesgo situado por ideales de calidad, mejora, eficiencia, entre otros. La importancia de esta perspectiva, está en entender a la organización, en este caso el hotel, por lo que es. Un hotel es un área física donde un cúmulo de elementos están haciendo impacto en nuestros diferentes sentidos. El enfoque simbólico permite ver a la cultura como la propia realidad del hotel, en la cual se inserta el trabajador y donde los eventos, las palabras, los objetos, los sonidos, las formas de interactuar, entre otros elementos, son vistos como símbolos a los que los trabajadores atribuyen significaciones. Bajo la perspectiva cognitiva, estos elementos no son tan fácilmente maleables como lo serían bajo la perspectiva de variable. O mas bien, la misma perspectiva de análisis no los percibe como herramientas para obtener utilidades en la organización. Por su parte, promueve la reflexión sobre la presencia o ausencia de determinados valores, roles e ideologías sociales en la empresa.

El hotel, como organización, es planteado entonces como un constructo complejo que representa una pequeña parte de la vida social. Por ello, la subjetividad presente en la interpretación de los individuos dentro de una organización, de acuerdo con Hatch (1993) interviene en la manifestación misma de la cultura.

Lo anterior dota de un papel activo al trabajador en la concepción de cultura. A su vez, abre el concepto a elementos socio-psicológicos que ofrecen mayores elementos para profundizar en el entendimiento de una organización, y por lo 
mismo, lo amplia aún más al considerar la posibilidad de subculturas. Si la cultura está en parte subordinada a la interpretación de los trabajadores, entonces las interpretaciones están filtradas por los diversos intereses y formas de entender al hotel. Estas interpretaciones son socializadas y compartidas en subgrupos dentro de la organización, quienes conforman tan sólo un fragmento de cultura de toda la entidad. El hotel se presume como un conjunto de subculturas.

Se rescata entonces una analogía bajo este enfoque: así como conocer las particularidades de una organización nos permite ampliar el conocimiento sobre el paisaje organizacional, enfocar el interés en alguna de estas subculturas, permitirá profundizar en el conocimiento de una organización en particular.

Por otra parte, la cultura no debe ser vista de una forma absoluta. En la realidad, la organización vista como una cultura, no es una suma de elementos que se relacionan entre sí en un punto congelado del espacio-tiempo. La cultura es un proceso, en el entendido que sus elementos mantienen una dinámica continua. Así mismo, el hotel en determinado punto, es causa de un momento anterior y consecuencia de un momento futuro. La ideología, las interacciones, las sensaciones van evolucionando, no son estáticas ni absolutas; los significados lo hacen de la misma forma.

Entonces, ¿cómo estudiar a un hotel bajo esta lente evolutiva? El cambio 
organizacional ${ }^{3}$ es una opción para abordar el objeto de estudio a través del tiempo, aplicable en diferentes niveles de la organización. De acuerdo con Lewin (citado en Arellano \& Cabrero, 2000:78) "no resulta sorprendente encontrar diversos tipos de cambio organizacional, que se suceden en distintos niveles y con diferentes grados de complejidad. En efecto, puede hablarse de cambio como un fenómeno que abarca a toda la organización pero también involucrando sólo una parte de ella y; como lo han presentado algunas teorías del comportamiento, también se pueden identificar procesos de cambio en el nivel de análisis más bajo, aunque no más sencillo, en el nivel de los individuos".

Y aunque la amplitud de nivel de análisis del cambio organizacional, permite enfatizar en la interpretación de los trabajadores, referente a su organización; se centra en las diferencias encontradas entre un punto inicial y un punto final, y el trayecto entre uno y otro. El contraste entre distintos momentos, aún visto como un proceso, mantiene un enfoque lineal y exige de un mayor tiempo en el campo de estudio, para observar la manera en que evoluciona el objeto de estudio a través del tiempo. Recurso con el que no se contó en la elaboración de este trabajo, con la amplitud requerida.

Además, al encapsular el objeto de estudio en un análisis temporal más lineal, se deja de lado que cuando se trata de interpretaciones de la realidad, los actos que conforman esta realidad, son percibidos en temporalidades completamente distintas por los individuos. Por ejemplo, los ritmos y la sensación del paso del

\footnotetext{
${ }^{3}$ Verlarde (2003) refiere a la relación entre Calidad y los modelos organizacionales en su estudio de caso en un hotel, a partir del Cambio Organizacional.
} 
tiempo, inciden en la particularidad de los actos de las personas, produciendo un espacio distinto en la organización. El tiempo no se percibe igual cuando se está ocupado, preocupado, agitado, en calma, reflexivo, ocioso, cansado, entre otros; la dinámica, o el performance, es diferente.

De ahí, que este trabajo se centre sólo en la perspectiva de la cultura organizacional, y más específicamente en lo contenido en las reinterpretaciones que se hacen del espacio, cuando se plantea como un concepto performativo: el Spacing Organization.

\section{ii. Lente Performativa del Espacio}

En el análisis espacial de las organizaciones el Spacing Organization (Beyes y Steyaert, 2011), es un concepto que permite visualizar a la organización como un constructo de diversos espacios. Cada espacio, diferente en cierta medida de los otros, se involucra con los demás de manera continua y paralela, en el sentido que están presentes en un mismo momento y mantienen una interacción a partir de los actos presentes de los individuos. Abordar a una organización como esta superposición de diferentes espacios, permite reflexionar cómo es que un hotel puede ser vivido en un mismo momento de maneras tan distintas, y en los elementos que intervienen para que sea así, es decir, conocer a la organización cómo es, a través de un enfoque más cercano a su dinámica continua: el performance ${ }^{4}$ de los trabajadores.

${ }^{4}$ Derivación de fournir (Fr). El uso de este término como neologismo en este trabajo, aunque no es parte del Diccionario de la Real Academia Española, busca mantener un sentido calificativo de cualidad por la cual no sólo se definen las cosas o realidades que uno hace, sino que también se producen o realizan, por el propio hecho de ser actuadas bajo un contexto 
En esta organización hotelera esta diversidad de espacios es perceptible si se contrapone al huésped con el trabajador operativo del hotel. En este caso, los trabajadores se encuentran trabajando en un área destinada al descanso de los huéspedes. Los huéspedes van en busca de un lugar de recreación y relajación, donde los trabajadores resuelvan y satisfagan diversas necesidades del propio huésped. Ambos se desenvuelven en un ambiente de continuo movimiento, pero el espacio es vivido de distinta forma. Para el huésped lo que sucede en el hotel, sólo le es importante y por ende lo percibe, siempre y cuando afecte su estancia y objetivo de descanso. Las políticas de uso de las áreas físicas del hotel son su único límite, y hasta éstas están hechas de manera que el huésped no se sienta limitado u ofendido. Sin embargo, para el trabajador los lineamientos, políticas y procesos formalizados acotan su actuar diario y les proporcionan procedimientos que parecieran difíciles de corromper, debido a los tiempos que deben cumplir para el desempeño de las múltiples actividades. Todo debe ser hecho en tiempo y forma. Las contingencias nacientes del servicio al cliente que emergen de manera continua, así como la necesidad de descanso y reducción de la presión sobre ellos, flexibilizan estos procedimientos rutinarios temporalmente, por cortos, pero frecuentes, periodos de minutos.

El espacio en el que se desenvuelven los empleados se diferencia del espacio en el que se desenvuelven los huéspedes del hotel: Ambos se encuentran en

determinado. La acción misma crea una realidad concreta, le dota de una primera forma y continúa durante el avance de la formación de la acción misma; Y que palabras en castellano como actuar, desempeñar, representar, realizar, entre otras, pudieran derivar a otro tipo de lectura, donde la atención se centra fuera del ser, contraria de lo que se busca referir. 
una misma empresa, una misma área física y, sin embargo, el espacio se percibe diferente.

Los mismos empleados, a su vez, parecen hacer uso de esta distinción de espacios para integrar los elementos que se encuentran presentes en su ambiente de trabajo. Es decir, así como el huésped y el trabajador estando en una misma área física se desenvuelven de manera diferente y perciben a la organización de manera distinta. El trabajador de un hotel participa en la performación de varios espacios para la realización de las distintas actividades por ejecutar en su día laboral. No es el mismo espacio aquél donde se atiende al huésped, como aquél donde se forjan vínculos amistosos y de complicidad, o aquél donde la operación del hotel te obliga a acelerar el ritmo de tus actividades como en una sensación de "detrás de cámaras" oculta al huésped.

El hotel es el mismo, pero los espacios no. Estos interactúan en las áreas de trabajo establecidas e inciden en ellas. El área física es sólo un referente del espacio que se está construyendo en el actuar diario de los trabajadores de hotelería. El trabajador percibe a la organización a partir del espacio que está performando en ese momento.

El espacio es un concepto de percepción y construcción continua que hace referencia a diversos elementos que contextualizan el momento en el que están situados los trabajadores. Esta referencia no es absoluta, existen diversas interpretaciones. Retomando el papel activo del individuo en la interpretación de 
la organización (Hatch, 1993), cada trabajador percibe diferente y su sensibilidad está orientada a particulares intereses, por lo cual se supondría que para comprender la construcción del espacio de una organización, debiera atenderse a la percepción de cada trabajador, pero en una organización las interpretaciones son compartidas. De acuerdo con Smircich y Stubbart (1985:727) el conjunto de personas comparten creencias, valores y supuestos que refuerzan las interpretaciones de los actos. Por lo cual, cada interpretación compartida de los actos puede ser vista como una lógica que le da sentido a un espacio. La organización es vista como el resultado de la multiplicidad de estas lógicas; una empresa, múltiples espacios.

\section{iii. Aspectos Metodológicos.}

El análisis del espacio en un hotel, toma como base el anterior planteamiento, para dar forma al cuerpo de este trabajo. El espacio performativo no implica solamente una concepción distinta del espacio, sino mantener esta concepción en el trayecto de la investigación a realizar. Beyes y Steyaert (2011:53) proponen la invención y experimentación de nuevas formas de metodología para la realización de las investigaciones. La investigación debe ser vista en sí misma como "performativa, formada a través de prácticas sociales". Al tratar el espacio performativo como un foco de análisis en la organización, se puede caer en equívoco de considerarlo algo capaz de ser extraído en el proceso de la investigación. 
En este caso, el análisis debe ser planteado de otra forma. Los métodos de investigación, invitan al investigador a mantener una visión objetiva del objeto de estudio. Ello podría empujar al investigador a concientizarse durante el proceso de investigación, fuera o ajeno a los fenómenos estudiados.

El observador del espacio performativo, sigue la lógica de la observación participante, y la lleva a un nivel más sensible de la concientización de su presencia en la performación del espacio. El espacio performativo busca ser analizado a partir de metodologías que prioricen la representación de la cotidianeidad lo más apegado posible, a la manera en que es vivida. Es decir, el investigador se coloca en una posición clave tal, que le permite apreciar y sentir la manera en que el espacio se va performando con las interacciones de los objetos, el área física, las personas y el ambiente. De tal forma, la organización va cobrando sentido a partir de la recolección de las sensaciones e interacciones observadas. El objetivo es claro, al no buscar generar un diagnóstico de lo observado, sino presentar a partir de la descripción, la realidad que se performa y se traduce en la organización.

La descripción dada a partir de la escritura de lo sentido y observado por el investigador, sigue la misma línea; la forma de escribir utilizada, debe ser enfática en proporcionar una clara proyección de los ritmos y la simultaneidad de las sensaciones percibidas y las reacciones proyectadas. La metodología necesaria para el manejo de conceptos performativos, requiere de la creatividad del investigador para llevar de la mano al lector entre la multiplicidad de actos, 
las redes de interacciones que se desarrollan y el énfasis de la participación de los distintos elementos.

La redacción del investigador debe dirigir al lector entre la superposición de los distintos espacios que se van performando. El tiempo no es lineal, se subordina al amplio rango de sensaciones del momento; de la misma forma que se presenta en la realidad.

Entre las opciones de metodología para este tipo de análisis, la narrativa inserta en un estudio de caso ofrece características sustanciales que se alinean a los propósitos del manejo de conceptos performativos.

Específicamente en los Estudios Organizacionales, el uso del estudio de caso se ha preferido frente a otras metodologías cualitativas, por su afabilidad con los límites y alcances propuestos en este tipo de investigaciones.

La profundidad planteada en los objetivos de investigación de las organizaciones, se acomoda a esta forma particular de recolección de datos. El principal beneficio es su característica de permitir delimitar el objeto de estudio a una entidad específica donde sus características particulares cobren gran relevancia para la obtención del conocimiento. La descripción de estas características observadas en la entidad, ofrecen una lente amplia del gran número de elementos que contribuyen en la realidad, y que son subordinados, en las investigaciones de carácter menos subjetivo, en la búsqueda de la 
generalización. Como herramienta metodológica atiende efectivamente tres profundidades de una investigación cualitativa: descripción, explicación y comprensión del objeto de estudio (Tellis, 1997:3). El estudio de caso ofrece una voz a las perspectivas y experiencias, a las que tradicionalmente cuesta obtener acceso (Hornillo y Sarasola, 2003:374).

Como ya se mencionó, parte de la importancia de realizar el estudio en una empresa hotelera, reside en la misma naturaleza de su giro, la cual no ha sido analizada bajo la perspectiva de los Estudios Organizacionales fuera de los conceptos de Calidad o Productividad ${ }^{5}$ y cuyas características particulares (como empresa de servicio) permiten observar de manera más enfática, la diferencia de los públicos a tratar, bajo lógicas un tanto disímiles como lo es el servicio al cliente y la generación de utilidades. En este caso, la entrevista y la observación permiten la obtención de los datos necesarios, sin embargo la técnica en que es presentada (redactada) la información debe ir más allá de una descripción exhaustiva. Los métodos narrativos no sólo retoman aquellos detalles que acompañan inherentemente a la experiencia personal, sino que se apoyan en la creatividad del investigador para darle cohesión y orden -un sentido- al contenido emocional recopilado, para después ser analizado.

En esa línea, Dorothy Ettling (1998 citada en Hornillo y Sarasola 2003:377-78) habla de la intuición. La intuición deposita en la investigación al investigador

\footnotetext{
${ }^{5}$ Es importante destacar los trabajos realizados por investigadores académicos de la Universidad del Occidente, en Mazatlán Sinaloa, que en conjunto con las líneas de investigación del Posgrado en Estudios de Organizacionales (doctorado), han abundado en temas relacionados con las empresas turísticas, específicamente los hoteles -como ejemplo: Velarde (2003)-; Pero que, a diferencia de este trabajo, enfatizan en la gestión estratégica, procesos de toma de decisión y la productividad.
} 
como persona creativa, característica afín a la narrativa.

Así la narrativa, usada como metodología, permite "explicar de forma integradora y personal la relación entre la recogida de datos y el análisis de los mismos además de distintos niveles de escucha." La narrativa tiene un vínculo directo con la acción, "las narrativas presentan un diálogo informado por las propias historias personales - el llamado privado - pero no tienen porque ceñirse a ello" (Biglia y Bonet, 2009:5).

La narrativa se presenta como una metodología que permea el punto de vista del investigador, dirigen la atención a una, de múltiples e infinitas, formas de interpretar la realidad. En su relevancia "no necesitan conformarse como texto único y coherente (...) [por su parte, se] insiste en el carácter de producción colectiva de las narraciones tanto en el caso de que sean fruto del intercambio entre "la entrevistadora y la entrevistada" como en la situación de que se basen en la combinación de materiales producidos en encuentros entre múltiples subjetividades" (Biglia y Bonet, 2009:5-6).

La narrativa como una metodología retoma la particular visión del análisis narrativo, al considerarla como un performance particular del narrador (Riessman 2002 en Biglia y Bonet, 2009:6). En esta metodología se reconstruye una realidad performatizada a partir de la memoria y el momento en que se escribe y analizan los datos.

Tan solo en la forma de leer e interpretar los datos se hace perceptible el 
performance del investigador ${ }^{6}$. Lo anterior no implica que la investigación cuente con información manipulada a la conveniencia o interés del investigador. El investigador hace conciencia de su participación y se sumerge en el caso, pero paralelamente mantiene una conciencia de agente externo al momento: es personaje y narrador.

Para esta participación, se hizo un primer acercamiento a la empresa, el cual fue un poco accidentado, puesto que después de una observación general, la Gerencia decide hacer una presentación formal del investigador con los mandos medios; la sensación en el personal de ser evaluados no pudo disiparse hasta después de unas semanas, cuando los trabajadores se familiarizaron con la presencia del investigador y se permitieron tocar temas más sensibles: familia, represiones, miedos, anhelos, rumores y propósitos de vida.

A partir de ello se entrevistó, de manera semiestructurada, al gerente general del hotel, a los mandos medios de los departamentos de recursos humanos, contabilidad, ama de llaves, concierge y alimentos y bebidas. De igual forma, se entrevistó a nueve elementos operativos de las diferentes áreas, ya mencionadas, uno de mantenimiento y uno de la constructora para tener una apreciación de los distintos grupos internos. Se decide entrevistar de manera

\footnotetext{
${ }^{6}$ Un ejemplo de ello, y ligado a la búsqueda de explorar la creatividad, es Dorothy Ettling (1998 en Hornillo y Sarasola 2003:378) quien escucha las entrevistas realizadas en su investigación desde tres modos de intuición distintas: “(a) escuchando desde su propia reacción emocional hacia la entrevista, seguido de una forma de expresión creativa para integrar y concluir la experiencia; (b) escuchar por el tono emocional de la voz y palabras de la entrevistada; y (c) escuchar y leer, intentar ser testigo de lo que había escuchado, permitiéndose así misma que el material actuase sobre ella, en vez de simplemente actuar sobre el material". En los tres casos, la investigadora trabaja con los datos desde una visión personal. Ella adquiere un papel protagónico en la interpretación de los datos y el orden elegido para presentarlos. Ofrece una visión singular de la situación dada, a partir de sus propios referentes -tonalidades, humor, conceptos, lengua-y los entrelaza con los datos duros y la experiencia vivida en todo el proceso del estudio.
} 
semiestructurada, para dar lugar a una apertura en los temas que priorizan los entrevistados y la manera en que los van vinculando. La información recabada permitió identificar sus intereses y relacionarlo con los actos observados.

En un periodo continuo de dos meses y medio se realizó la observación al área operativa. La primera etapa de la observación fue prospectiva, para identificar los horarios manejados en la semana laboral, de ahí se dio seguimiento a través de la observación participante, específicamente en el área de ama de llaves y concierge. La transición entre ambos tipos de observación se dio de manera paralela a la familiarización del personal con el investigador.

Dentro de esta transición fue importante que el investigador dejara saber a partir de sus comentarios y disposición a ayudar en las actividades, el conocimiento que se tenía sobre la hotelería y sus procedimientos técnicos. Sólo así los trabajadores identifican al investigador "como uno de ellos". Además de las entrevistas, se grabaron también en audio, escenas específicas de interacción de los trabajadores operativos con sus diferentes públicos. La información recolectada se ordenó de acuerdo a las cuatro categorías propuestas en este trabajo, para el análisis del espacio operativo. Así mismo, se tomó nota de sensaciones, actos, gesticulaciones, tonos de voz, vocabulario, posiciones dentro del espacio y actitudes de los observados.

En la performación de la narrativa, el investigador utiliza su papel de personaje para adquirir información amplia que ocupará como nexos y conjunciones que le darán orden y sentido al momento de enfrentarse al caso como narrador, y se 
ocupe de describir y comunicar los significados dentro del contenido y el contexto de las historias entrelazadas en la narración.

La importancia radica en la habilidad para cortar y pegar las diferentes partes del material, dotando de coherencia al desarrollo de la narrativa (Booth, 1996 en Hornillo y Sarasola, 2003:378). La dualidad de papeles permite al investigador presentarse, a través de la narración, bajo un solo papel: narrador omnipresente.

El investigador a su vez, por medio de un diario de investigación, recolecta las propias sensaciones y detalla la experiencia de situarse en el hotel y en la performación del mismo espacio; Describe percepciones, preconcepciones, juicios y ausencias de información que lo predisponen, y la evolución de estas sensaciones e información, mientras se compenetra más en el estudio de caso.

Los datos son utilizados para dar forma y continuidad a la narrativa de los trabajadores, como un referente lo más verídico y ajustado a la percepción de los trabajadores observados -ponerse en los zapatos de-. Es decir, la interpretación hace referencia a las sensaciones del mismo investigador, para desarrollar una narración única coherente a partir del "corta y pega" de las múltiples narrativas de los entrevistados. La honestidad frente a los datos, dirige "al investigador a experimentar con distintos modos de representar lo encontrado de la mejor forma posible". Una forma de reconstrucción creativa del mundo (Booth, 1996:246 en Hornillo y Sarasola, 2003:378). Así mismo, para respaldar la confiabilidad y validación al estudio de caso, se tuvieron en cuenta las tácticas recomendadas por Yin (1994), sobre la validación del constructo, la validación interna, la validación externa y la confiabilidad. 
Bajo esta línea dinámica y creativa, el presente trabajo se estructura en una dialéctica símil a la derivada en el proceso de la investigación, retomando la teoría necesaria, conforme las categorías del concepto de espacio performativo -propuestas en este trabajo- las fue requiriendo.

Cada capítulo hace hincapié en una de estas categorías y a su vez profundiza en algún concepto clave en específico: espacio, público o personaje; para finalizar en un análisis más claro de la multiplicidad de los espacios dentro del hotel. Así, se divide en seis capítulos, en el orden a continuación señalado: en primera instancia el primer capítulo hace una presentación de la organización seleccionada como estudio de caso y un acercamiento al enfoque de espacio performativo dentro del hotel.

A partir de ello se propone una categorización con los elementos retomados de un concepto performativo, para la operatización de la teoría, como parte de la metodología usada, y que permitirá la comprensión del concepto espacio en el hotel. En los siguientes cuatro capítulos se definen las categorías y los elementos que intervienen en ellas, culminando con un sexto apartado de conclusiones y observaciones complementarias al trabajo. El sentido vital de la estructura del trabajo es proponer una forma más articulada de la teoríametodología-estudio de caso, sustentada en la búsqueda de una presentación de la información más afín con la esencia del spacing: promover el dinamismo en cada aspecto del proceso de investigación. 


\section{CAPÍTULO 1}

El hotel como espacio performativo:

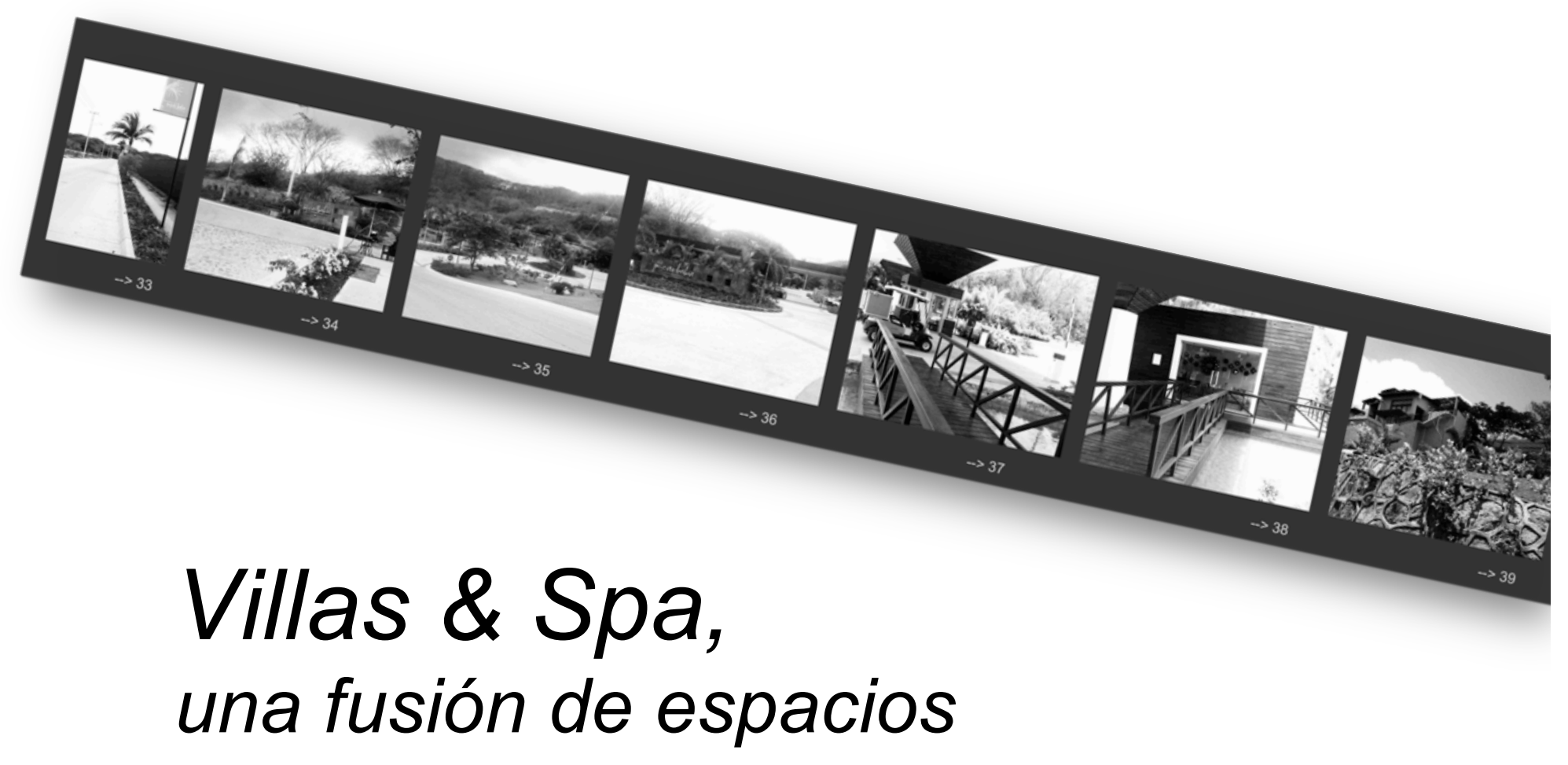




\section{CAPITULO 1. EL HOTEL COMO ESPACIO PERFORMATIVO}

"Think of space as a verb, not a noun"

(Beyes y Steyaert, 2011:56)

La Riviera Nayarit es una región turística de playas mexicanas al norte del río Ameca que se ha destacado fuertemente en las últimas décadas a nivel nacional, cuenta con desarrollos residenciales y hoteleros de calidad internacional: hoteles hasta de 4 diamantes, Spas \& Healing Centers, Suites Residenciales y Villas en modalidades tan diversas como tiempos compartidos, all inclusive, fractionals, entre otros, dirigido a público de clase media alta, alta y extranjeros (americanos y canadienses en su mayoría). Está compuesta por diversas ciudades nayaritas, pertenecientes al municipio de Bahía de Banderas (al sur del Estado), en las que destacan Nuevo Vallarta, Punta Mita, Bucerías y Cruz de Huanacaxtle; es en ésta última donde se construye el desarrollo turístico de Villas \& Spa (V\&S).

\subsection{PRESENTACIÓN DE LA ORGANIZACIÓN}

V\&S recibe al huésped con una amplia glorieta, escondida entre unas colinas arenosas atravesadas por un camino que se despliega un kilómetro hacia dentro de la carretera a la Cruz de Huanacaxtle. El desarrollo turístico de V\&S es un terreno amplio de un par de hectáreas que alberga, en esta etapa inicial de un proyecto más ambicioso, un condominio horizontal (villas) y un condominio vertical (apartamentos) designados a prestar servicios hoteleros.

V\&S se presenta ante el huésped "como un desarrollo de lotes, villas y 
condominios erigidos en un lugar donde el lujo y el viejo México se fusionan en un ambiente bello y de tranquilidad ${ }^{7}$. Sin embargo el espacio de $V \& S$ es más que eso; el Spacing supone un trayecto de sensaciones que interactúan entre sí y responden a un momento. Implica no uno, sino varios espacios que participan en la formación de una organización. Cada uno de estos espacios, responden a esta misma lógica, la formación a partir de lo vivido: el espacio performativo.

Para vivirlo, hay que desplegarse sobre la carretera a la Cruz de Huanacaxtle y observar un gran anuncio de piedra labrada a la orilla de la carretera que indica el camino a V\&S. Los estandartes publicitarios verdes, pregonando la proximidad del desarrollo, dirigen al huésped a través de un largo camino pavimentado hasta un guardia de seguridad que se cubre del sol bajo una sombrilla y que pocos metros antes de revelarse la entrada principal le ha preguntado: " $¿ A$ dónde viene?" Al resolverse la duda, el guardia ofrece direcciones y hace uso de su radio para anunciar/confirmar la llegada. Detrás de él viene también una camioneta blanca a la que el guardia de seguridad ha dejado pasar sin pregunta alguna. Se baja una pequeña curva hacia la izquierda y la glorieta se descubre. El verde de sus jardines y palmeras se funden con el brillo de los retoques lujosos de madera y piedra que visten a la caseta principal de Vigilancia y a la Recepción, localizada a mano derecha de la caseta, justo al final de un pequeño puente de madera en tonos de caoba, que cruza las aguas de un riachuelo que le rodea, al estilo oriental. El mensaje es claro: estás atravesando a un lugar distinto.

\footnotetext{
${ }^{7}$ Recuperado de las redes sociales y el sitio web de la organización, que se mantiene en anonimato.
} 
El huésped no hace hincapié en ello, pero del otro lado del puente ha dejado más que el auto; ha dejado rutinas, algunas preocupaciones, hastío y esa sensación del tiempo que apremia a producir constantemente. Al cruzar el puente se le recibe con una copa de champagne o bebida de su predilección, y al beberla está aceptando un rol${ }^{8}$. El huésped sabe que está ahí sólo para recibir y no para dar. Es verdad que hay un pago de por medio, pero eso sólo potencializa la creencia de "merecer atenciones"9.

Los concierge $y$ bell boys han atendido con sumo cuidado cualquier especificación del huésped, ya le han observado y con la experiencia en el ramo hotelero reconocen cuál es el mejor tono para hablarle y de qué manera lograr empatía con él. La cordialidad roza con la sumisión, y sin hacer uso del contacto físico -a lo mejor y se llegan a estrechar las manos-, se le ha hecho saber bienvenido de forma cálida y familiar. Después de una serie de preguntas el check-in está listo. El huésped ha dejado la información requisitada que lo avala como el sujeto merecedor de dichas atenciones. El tiempo del registro lo ha determinado él. El aire acondicionado permite distanciarse de la brisa húmeda que incomoda y prolonga hasta el más sencillo trámite y la bebida ha ofrecido el pretexto perfecto para que tome asiento, se relaje y baje la guardia en la transacción que está haciendo -y que podría hacerle recordar todo aquello que ha dejado a la orilla del puente-. Su villa le espera. Vuelve a cruzar el puente pero ahora es un carrito de golf el que lo recibe. El contraste del aire acondicionado con la humedad le indica que es verano, y es lo único que

\footnotetext{
${ }^{8}$ Algo similar al "derecho moral" mencionado por Goffman (1959): el individuo les ha hecho saber lo que "es", y por ende debe ser tratado por los otros como lo que los demás entienden por ese "es".

${ }^{9}$ Para Goffman (1959) esto sería el uso de una técnica llamada "práctica defensiva", que se utiliza para proteger la proyección que una persona da de si.
} 
importa. El auto se ha llevado consigo a la rutina y los días entresemana. La otra realidad ha comenzado.

Es cierto que el espacio, como un concepto performativo, no sólo es referente físico, como lo plantea Hall, sino resultado de la misma dinámica de aquel comportamiento. Pero Hall (1972) permite enfatizar en la particularidad de la experiencia vivida dentro de un mismo espacio, por parte de distintos actores, aún en lo concerniente a la temporalidad. Para él, "el lenguaje prolonga la experiencia del tiempo y el espacio" (Hall, 1972:9). Por lo tanto, la interpretación del espacio es resultado de los actos -por ejemplo el lenguaje-, que se permiten las personas dentro de éste. El espacio entonces, participa en la formación de las relaciones estrechadas al interior de la organización; nuevamente estaríamos hablando de su participación en la dinámica organizacional.

Las villas están equipadas en su interior con lujos tales como piscinas privadas, cocinas integrales y amenidades de gran detalle, cuentan en el área común con restaurante, alberca, bar, sport club, gimnasio, oficinas, spa, estacionamiento y vías de comunicación entre sí, donde se hace uso de los carritos de golf (operados por los concierge y los bell boys), para disfrutar del clima y la flora que embellece el derredor.

El bell boy continúa con la presentación del desarrollo mientras saluda con un movimiento rápido de cabeza a unos compañeros de trabajo que rebasan en ese 
instante, ellos responden a su saludo. El huésped les sonríe, ellos se ven obligados a hacerlo también y prosiguen el viaje hasta la villa.

El concierge ve partir el carrito de golf, ajusta la mandíbula, no ha sido forzado en ninguna de sus gesticulaciones, pero se denota que enfocar la atención en otra persona le cansa. Nuevamente el lenguaje permite que se prolongue el sentido de un espacio (Hall, 1972). No hace falta que se diga nada. Trabajadora4 quien se encarga de limpiar las áreas públicas, estuvo ahí todo el tiempo de manera anónima, atraviesa la recepción, sale, regresa con un trapeador, y borra las huellas dejadas por el huésped en el puente de madera. Voltea a ver a su alrededor y saca del cuello de su playera un audífono que había escondido cuando el huésped bajaba del auto. Lo coloca en su oreja y tararea con la mirada. Sigue limpiando la recepción.

Trabajadora4, el bell boy y el concierge, han cruzado sin fin de veces ese puente y la sensación no se compara en lo más mínimo a la del huésped. Si bien Hall (1972), refiere al espacio en gran medida a un área física, sus observaciones no se alejan de la concepción del espacio performativo, debido a la importancia que reitera en los sentidos para la construcción del espacio. Es decir, percibe al espacio como referente para el comportamiento específico del humano a partir de las percepciones sensoriales. En el hotel sigue estando un riachuelo, sigue viéndose verde y sigue un diseño de jardín oriental que apacigua a la retina más colérica. Hall (1972), así, le otorga en primera instancia, un sentido muy individual a la concepción del espacio. Ya que depende de cada persona lo que se aprecie en el área física. Es claro que el área física no determina la totalidad 
del espacio en el que se sitúa el trabajador. Su rol dentro de éste, también construye la imagen de sus percepciones y el espacio cambia.

Un trabajador en V\&S comparte con otros compañeros de trabajo un contexto nayarita (por ponerle un nombre, y del que se hablará más adelante) que es referente en el proceso de interpretación de la realidad, también puntos de vista a partir de su formación académica y de acuerdo a Smircich y Stubbart (1985:727), al encontrarse dentro de una organización "comparten creencias, valores y supuestos que fomentan el refuerzo de las interpretaciones de sus propios actos y los actos de otros".

Para Trabajador1, V\&S lo recibe a la orilla de la carretera, es una camioneta blanca que ha ido por aquéllos que entran a cierta hora y llegaron hasta diez minutos antes. Baja del camión en el que venía, entra a la camioneta que lo lleva por el camino de un kilómetro de distancia y agradece haber llegado a tiempo para no tener que caminarlo bajo el sol, como en otras ocasiones le ha pasado.

El guardia bajo la sombrilla, los saluda y registra algo en su bitácora. Cruza la glorieta, traspasa la caseta principal y desciende. Ir en la camioneta le asegura que ha llegado temprano, por lo que no duda en saludar a todos. Se acerca a la caseta principal y presiona su dedo en el checador: "Buenos días" se lee en la pantalla. El día laboral ha comenzado. El riachuelo y los jardines no son parte de sus labores, por lo que no ha prestado gran atención en ellos. Si acaso los ha usado como fondo para sostener la mirada en sus pensamientos: la comida 
dejada en casa, las cuentas por pagar, la novia, los proyectos de vida, la mejor estrategia para ganar este año el torneo de futbol y algunos pendientes; mientras la camioneta cruzaba la caseta y se estacionaba. Alcanza a ver a un desconocido en la Recepción que sugiere ser un huésped, y le recuerda que el tiempo corre y hay que ponerse al día para saber como distribuir las actividades. Tiene una idea previa de como dejó el trabajo ayer, pero en los hoteles "siempre surge algo". Ni siquiera respiró hondo o se tomó un tiempo para saber a dónde ir. Mientras camina directo a su lugar de trabajo, platica con otro compañero. Comentan algún chisme que se haya suscitado en la tarde-noche de ayer. Entonces son rebasados por un carrito de golf, donde viene el bell boy conversando con el huésped. Él baja la voz, le regresa el saludo al bell boy y atiende la presencia del huésped devolviéndole una sonrisa nerviosa. Su compañero ha hecho exactamente lo mismo, de hecho sus cabezas se han agachado un poco en ese momento. Al aproximarse a su destino, no se despiden: “¿A las dos?" -“No manches, no desayuné. A la una.”. Trabajador1 hace una mueca, piensa escasos segundos: " $\mathrm{V} V a$ !, Pero me avisas por la radio, porque luego se me va la onda". Eso último lo ha dicho casi a gritos mientras entraba por una puerta. Sonríe. El olor a café descubre los ojitos cómplices de sus compañeros de área, entrecerrados por el humo que despiden sus vasos de unicel. Unos minutos para organizarse. Inclina su vaso bajo el dispensador eléctrico del garrafón de agua, y mientras sorbe cuidadosamente para no quemarse, conversa, ríe y se alista. Su cuerpo está más relajado que cuando llegó a la caseta, o cuando pasó el huésped a su lado. La exposición de su 
persona en el hotel antes de haber llegado a su área pareciera que le apenara. Si bien ha platicado con otros, lo ha hecho como si se estuviera escondiendo, con prisa. Tan sólo ha gritado mientras se acercaba a su lugar de trabajo. Al cruzar la puerta de su área, algo cambió. Trabajador1 caminaba calmoso, la sonrisa se desenvolvió en risas y entones sí respiro hondo. Antes, ya había entrado al hotel, pero no había "llegado".

Tanto el huésped como el Trabajador1 han recorrido el mismo trayecto desde la carretera hasta el interior de V\&S. Su percepción del área ha sido distinta, así mismo, la actitud con la que se desenvuelven en ella, la reacción e interacciones con las otras personas también han sido diferentes. Han interpretado y jerarquizado el cúmulo de percepciones, a partir de su experiencia y expectativas hacia el hotel, a tal grado que su relación con el hotel no es la misma, aún compartiendo un mismo periodo de tiempo. Su realidad es diferente. El ejemplo del huésped nos permite puntualizar en lo evidente: Es una misma área física, es un periodo de tiempo compartido, pero los espacios son distintos. ¿Cómo es esto posible?

Trabajador1 ya ha hecho una reinterpretación de su espacio. V\&S le ha permitido a Trabajador1 constituir relaciones con otros compañeros de trabajo e interactuar con un sin fin de huéspedes. Esto le ha dado la posibilidad a su vez de reinterpretar su lugar de trabajo. Como lo mencionan Montaño y Rendón (2000:69), el conjunto de experiencias vividas colaboran en la construcción de estas imágenes o "reapropiaciones semánticas". Reapropiaciones que se 
despliegan en cadena mientras que Trabajador1 hace su camino hasta su área de trabajo. Es claro que Trabajador1 labora por una necesidad económica, pero al desenvolverse en el trabajo, necesidades sociales, profesionales y personales están siendo satisfechas.

Hacia adentro, V\&S se reconoce como un desarrollo hotelero de grandes expectativas, que cuenta con un equipo de trabajo joven, afanoso y en crecimiento.

Las exigencias de servicio buscadas en este desarrollo son tal, que podría suponerse exige un número importante de trabajadores, sin embargo la mayoría de ellos se encuentran orientados a la construcción del mismo desarrollo dejando un número aproximado de 40 personas para la parte operativa hotelera. La mayoría de los empleados, son oriundos de las localidades aledañas al hotel y su visión sobre el ramo hotelero, el trabajo, las relaciones y la vida en sí, dejan entre ver la historia que se ha ido desenvolviendo en esta zona del país.

La razón para que Trabajador1 se desenvuelva de múltiples formas dentro de las áreas de un mismo hotel, implica entonces una distinción del espacio elaborada en su mente a partir de lo que percibe -lo que interpreta-. $Y$ de acuerdo con Czarniawska (2004), estas múltiples formas (o actos) integrarán a su vez la realidad organizacional. El espacio de Trabajador1 es construido y se construye a partir de su performance y el de los demás que interactúan con él.

Es decir, el espacio se construye a través del rol, las interacciones, la interpretación de la realidad y el área física, la experiencia, la propia presencia y el tiempo -la "continuidad"- de esta construcción (Beyes y Steyaert, 2011)-. 


\subsection{CATEGORIZACIÓN DEL ESPACIO PERFORMATIVO}

El espacio, visto como un concepto performativo: spacing; imprime sentido colectivo a su construcción. Si bien, cada individuo tiene una percepción del espacio -caso del huésped y el trabajador-, en la dinámica organizacional las reapropiaciones semánticas se externalizan en los actos y las percepciones se comparten. En esta serie de reinterpretaciones e interacciones que hacen entre sí los trabajadores de V\&S, se llegan a acuerdos tácitos que se resuelven en concepciones de espacios en común. El espacio se percibe un tanto similar.

En este enfoque del análisis organizacional, el espacio deja de plantearse sólo como una concepción física (Hall, 1972) y temporal que incide en los actos de los participantes de una organización, y se presenta como un proceso, la formación misma a partir de estos actos y la reacción a esta construcción: spacing.

El concepto de spacing en el análisis organizacional, de acuerdo con Beyes y Steyaert (2011) está integrado por cuatro elementos ${ }^{10}: 1$ ) la práctica y el acontecer diario, 2) la interacción con el cuerpo humano, 3) las sensaciones y afectos que inciden en la intensidad de los apegos, vínculos y acciones, y finalmente 4) por el reconocimiento de la multiplicidad espacial y la política de segundo orden (micropolítica) -minor politics ${ }^{11}$.

\footnotetext{
${ }^{10}$ Estos elementos están basados en la práctica de la teorización no-representacional -non-representational theorizing(Anderson and Harrison, 2010; Cadman, 2009; Thrift, 2007 citados en Beyes y Steyaert, 2011:51).

${ }^{11}$ La multiplicidad de espacios, supone una apertura para más y más espacios en coexistencia (Cadman, 2009 citado en Beyes y Steyaert, 2011:52), la relación entre el spacing y la política de las minorías, implica la concepción del espacio como no-absoluto y en continua absorción de nuevas interpretaciones aún no concebidas y que se irán construyendo y haciendo parte del spacing.
} 
Concebir el espacio dentro de un hotel como spacing organization, implicaría entonces una perspectiva de análisis acorde a este concepto, que reconozca todas estas características como dinámicas y continuas. Los cuatro elementos mencionados deben ser percibidos como constituyentes de un producto resultante de la integración de ellos. Czarniawska (2004:783) percibe esta necesidad de cambio de perspectiva y lo plantea como un cambio de lo lineal a la concepción de red: una red de actos; la organización "no es un punto de partida" absoluto, sino el resultado de esta red.

Por lo tanto, la construcción de los espacios es un ir y venir de los trabajadores al entorno. La dinámica organizacional refiere a estos espacios y también a su vez, es referente de éstos. Las características del espacio, como concepto performativo, se relacionan entre sí. El dinamismo del que se dota al concepto no permite analizarlas de manera particular sin hacer alusión a las otras. Esta correlación permite establecer un análisis de los elementos básicos que interactúan a partir de cuatro categorías establecidas: temporalidad, performance, dinamismo e interpretación de la realidad (Ver Tabla1). Y que serán de utilidad en la estructuración de los siguientes capítulos, al momento de operacionalizar el conjunto de supuestos teóricos de cada uno de ellos. 
TABLA 1. CATEGORIZACIÓN DEL CONCEPTO PERFORMATIVO DE ESPACIO

\begin{tabular}{|c|c|c|c|c|}
\hline CATEGORÍAS & TEMPORALIDAD & PERFORMANCE & $\begin{array}{c}\text { INTERPRETACIÓN } \\
\text { DE LA REALIDAD }\end{array}$ & DINAMISMO \\
\hline TEMPORALIDAD & $\begin{array}{c}\text { Tiempo y } \\
\text { transitoriedad }\end{array}$ & Escenario Físico & Contextualización & Continuidad \\
\hline PERFORMANCE & Acontecer diario & $\begin{array}{c}\text { Comunicación: } \\
\text { Habla y Acciones }\end{array}$ & $\begin{array}{c}\text { Jerarquización de } \\
\text { espacios }\end{array}$ & $\begin{array}{c}\text { Interacción con el } \\
\text { cuerpo humano }\end{array}$ \\
\hline INTERPRETACIÓN & Espacio-Tiempo & $\begin{array}{c}\text { Vínculos y } \\
\text { Reacciones }\end{array}$ & $\begin{array}{c}\text { Relación con los } \\
\text { sentidos, apegos, } \\
\text { sensaciones y } \\
\text { afectos }\end{array}$ & $\begin{array}{c}\text { Reconocimiento de } \\
\text { la multiplicidad de } \\
\text { espacios }\end{array}$ \\
\hline DINAMISMO & $\begin{array}{c}\text { Dirección, } \\
\text { Trayectoria }\end{array}$ & $\begin{array}{c}\text { Movimiento, } \\
\text { Interacciones }\end{array}$ & $\begin{array}{c}\text { Acotación de la } \\
\text { realidad }\end{array}$ & $\begin{array}{c}\text { Interacción entre } \\
\text { todos los } \\
\text { elementos }\end{array}$ \\
\hline
\end{tabular}

Fuente. Elaboración propia con base en las características del espacio propuestas por los autores Beyes y Steyaert, 2011; Anderson and Harrison, 2010; Cadman, 2009; Thrift, 2007 citados en Beyes y Steyaert, 2011; Hall, 1972 y Czarniawska, 2004.

La relación entre estas categorías que grafica la Tabla 1 , permite localizar entre sus intersecciones los elementos en común, que conforman las distintas características del espacio, presentados por los autores Beyes y Steyaert, 2011; Anderson and Harrison, 2010; Cadman, 2009; Thrift, 2007 citados en Beyes y Steyaert, 2011; Hall, 1972 y Czarniawska, 2004, en sus respectivas publicaciones y la interpretación de las lecturas de éstas por parte del presente autor de este trabajo.

La intersección de una misma categoría (recuadros sombreados) define el tema central de la categoría correspondiente. Si bien no existe un orden específico para el análisis de las categorías, para efectos de este estudio, se inicia con la categoría de Temporalidad que nos ofrece un sentido de transitoriedad en la investigación, elemento básico que evoca palabras como efímero, pasajero y fugaz pero que realmente busca acentuar el hecho que el concepto de espacio en una organización no es puro y permanente, sino que atiende a un contexto, 
un tiempo si bien determinado, pero evolutivo. Hablar de espacio (del latín spatium), en sentido general, implica hablar de todo lo que nos rodea. El tiempo, en este caso, es parte inherente de lo que nos rodea. Es el lienzo sobre el cual se desdibujan las formas que percibimos en la realidad. El tiempo es una magnitud que nos denuncia un momento, una distancia entre un punto y otro. Esta distancia, la temporalidad, coloca y ordena los sucesos en nuestra mente. Para el espacio, el tiempo permite situarnos en momentos, dota de existencia. Su relación con el espacio materializa las acciones en el plano de la realidad. La transitoriedad de esta realidad es una característica básica de la temporalidad.

En la segunda categoría, el Performance, el análisis se centra en el comportamiento de los trabajadores dentro de ese contexto y como su interacción va incorporando y dando forma al espacio. Para Goffman (1959:11), "un performance puede definirse como la actividad total de un participante dado en una ocasión dada que sirve para influir de algún modo sobre los otros participantes".

De acuerdo con el autor, los actos de las personas, en este caso los trabajadores, se centran en sus públicos. Su desempeño, actitud y participación frente los públicos legitimará su rol dentro del espacio y frente a estas audiencias. Así mismo, la incorporación de lo percibido en el espacio reproduce una reacción en las interacciones de los trabajadores, retroalimentando al mismo espacio y participando en la producción de éste. 
En la tercera categoría, Interpretación de la Realidad, se dirige la atención a las percepciones formadas que acotan esta realidad de los empleados y le dotan de sentido al espacio. Los apegos, sensaciones y afectos propician vínculos y reacciones que constituyen una lógica en el desenvolvimiento de los trabajadores. Los sentidos son el medio utilizado para recabar los datos (percepciones) que serán ordenados, seleccionados y filtrados. Es a partir de ellos, y su relación con el entorno, que se encarnan los roles y se empalman entre sí, dando lugar a más de una sola forma de responder a las percepciones y así, a la performación de una multiplicidad de espacios, bajo una misma temporalidad.

El Dinamismo, como cuarta categoría, interviene como un eje cíclico de la percepción de los elementos que conjugan en la conceptualización del espacio. Refiere al reconocimiento de la relación entre todas estas categorías y sus elementos. La comprensión de una relación bilateral entre espacio y trabajador, donde todos los elementos no son sólo causa, sino consecuencia de ésta.

El espacio performativo (spacing) es la construcción misma a partir de estos elementos y la reacción a esta construcción: Producción y Evolución que no cesa. De tal forma, se cierra la conceptualización del espacio performativo, propiciando una correlación de sus elementos y con ello, una visión más amplia de su presentación en el mundo real. Los trabajadores toman un papel activo en la performación del espacio pero, a su vez equiparable, con el papel de los otros elementos aquí mencionados. 
Presentados así, con las cuatro categorías propuestas para el análisis del concepto performativo de espacio, los siguientes capítulos se estructuran de la siguiente manera: el capítulo segundo profundiza en la conceptualización del Espacio a partir del concepto de Spacing Organization retomado de Beyes y Steyaert (2011), donde el espacio deja de ser un término estático para abundar en su temporalidad y constitución como un concepto performativo, dinámico y continuo creador de la realidad organizacional a través de los actos que lo integran (Czarniawska, 2004), el objetivo es resaltar la relación existente entre espacio y tiempo para fortalecer una percepción menos absoluta del espacio en V\&S; el tercer capítulo define la categoría del Performance y entre sus elementos a analizar desarrolla la relación espacio-personaje con base en la metáfora de la teatralidad utilizada por Goffman (1959), para analizar la interacción entre personas y el uso de personajes en el acontecer diario de la organización; el cuarto capítulo retoma esta metáfora de la teatralidad a través del concepto del público y su relación con la categoría de Interpretación de la Realidad, el objetivo es atender como la interacción con distintos públicos permite una reinterpretación del mismo momento de la realidad, la acota; y el capítulo quinto aprovechará esta diferenciación para hacer hincapié en la categoría de Dinamismo, que permite, entre otras cosas, reconocer la existencia de una multiplicidad de espacios, y por lo tanto, atender el análisis del espacio performativo dentro del hotel en una forma más continua de interacciones entre todos los elementos presentados con anterioridad. 


\section{CAPÍTULO 2}

Temporalidad:

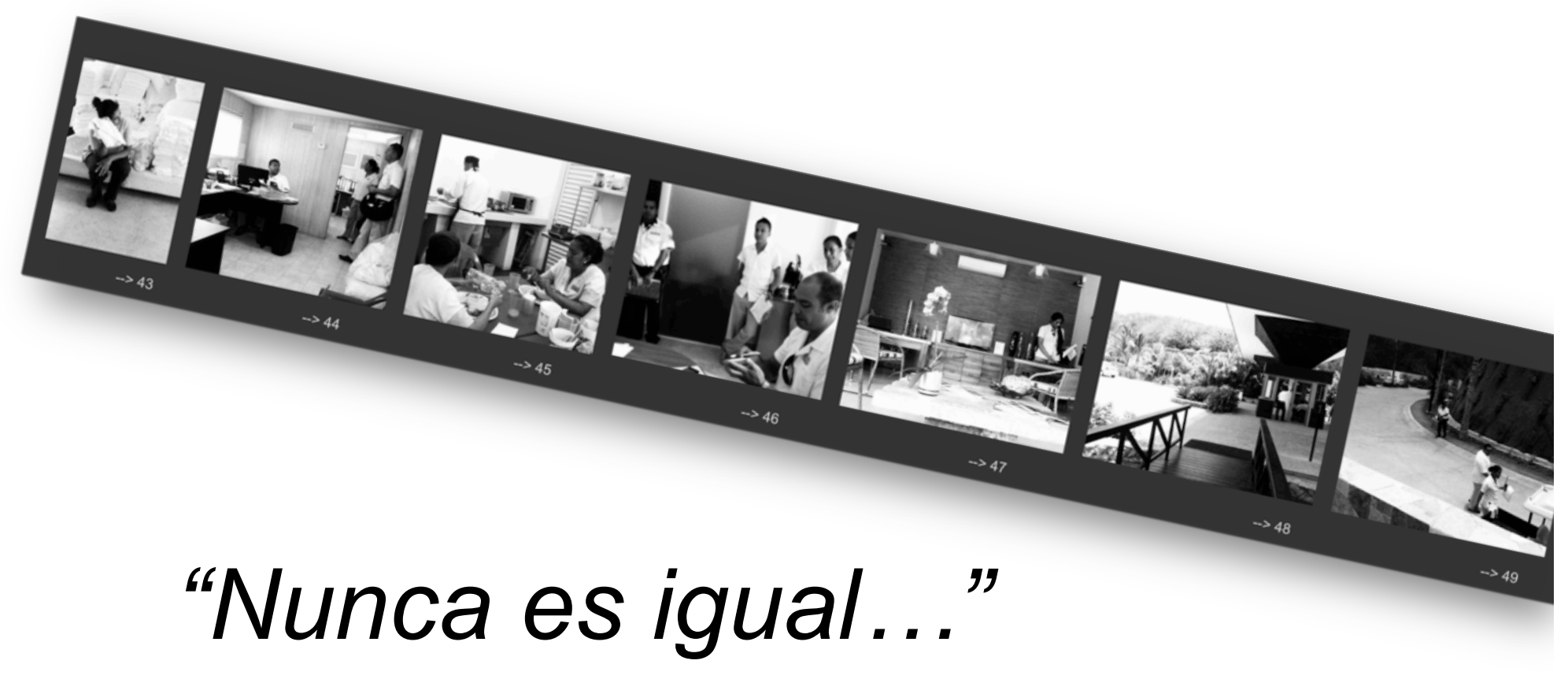




\section{CAPITULO 2. TEMPORALIDAD.}

El tiempo es una magnitud que nos denuncia un momento, una distancia entre un punto y otro. En la categoría de la temporalidad, uno de los elementos básicos de análisis es el momento donde se ubica la organización de V\&S, tanto geográficamente como contextualmente, y la manera en que impele determinado comportamiento frente a los distintos públicos con los que convive el trabajador del hotel. Hablar de temporalidad en V\&S, sería en primer instancia responder a la pregunta ¿cuándo? y ¿dónde? Pues en relación con el performance del espacio, la temporalidad captura el momento dentro de un escenario físico/temporal. El tiempo permite situarnos en momentos, dota de existencia. Su relación con el espacio materializa las acciones en el plano de la realidad.

\subsection{TIEMPO Y TRANSITORIEDAD}

Las actividades de los trabajadores responden a horarios, que se ordenan de acuerdo a las necesidades más próximas de ser atendidas. Es en esta categoría, donde lo urgente cobra sentido y las acciones son jerarquizadas.

En el acontecer diario, se puede percibir que el trabajador atiende las necesidades de cuatro figuras en general: el huésped, el jefe, el compañero de trabajo y él mismo. No son unos sucesos terminados y separables de la realidad, mas bien refieren a un contexto y son partícipes en una continuidad (Czarniawska, 2004). La forma de atender estas necesidades responde a la comprensión que tiene el trabajador del espacio de trabajo y así interpreta su realidad. El tiempo va construyendo junto con la actividad del trabajador, una percepción de los trayectos (distancia), la duración del día (jornada), la fatiga 
(recesos) y su rendimiento (productividad). El tiempo se relaciona con el compromiso de los trabajadores, cobra un sentido moral cuando se habla de puntualidad y eficacia, que evidencia la profesionalidad, valores y capacidad de los empleados.

“-Paga, no te hagas.

-¿Para qué llegas tarde?

-Todos tenemos cosas que hacer.

-¡Pues organízate papá!.”

(Briefing, comunicación personal, 27 de mayo 2013).

En V\&S la puntualidad es un valor requerido en los trabajadores. Los horarios de entrada están pensados de tal manera que la logística no se vea afectada. El tiempo por lo tanto es el punto de partida de la coordinación. A las 9:30 inicia el briefing en la oficina del Gerente de Hotel. Quien llega después de empezada la junta, debe pagar diez pesos, que se depositan en una alcancía. Ese dinero es utilizado con fines de recreación grupal, la medida es sólo una más de las técnicas para fomentar una cultura del respeto al tiempo ajeno: del huésped y de los compañeros de trabajo.

"No es que me queje. Pero para que llego temprano si siempre salgo tarde. No hay día que salga a mi hora. Y si dices algo, te dicen que así es la hotelería(...) Te absorbe (...) pero ahí andan, parece que no lo pueden dejar para mañana." (Trabajador3, comunicación personal, 09 de junio 2013).

V\&S es una empresa de servicio hotelero. La cultura hotelera parece dar por hecho que la puntualidad implica el momento preciso para iniciar una actividad, pero no así para terminar la disponibilidad del trabajador. El respeto es al tiempo 
ajeno, pero no al propio. El tiempo ocupado para las actividades laborales, no responde a una afinidad por la empresa, ni por el trabajo, sino por la naturaleza de las actividades: el servicio. El tiempo de uno se cosifica.

"Hay cosas que no se pueden dejar para mañana, me gusta dejar todo listo, sino luego me preocupo y ahí me ves llamando, o hasta me he regresado(...), es que te tiene que gustar (...) correr de un lado a otro y al final pues te vas todo sudado y muerto. Bueno, que te cuento, tú ya sabes, así es en un hotel, ¿o no?" (Trabajadora1, comunicación personal, 04 de junio 2013).

La percepción de la temporalidad segrega. No eres "de la hotelería", sino comprendes que para el servicio no hay horario de salida. Una semana laboral, puede implicar salir después de tu hora de salida, cubrir guardias vespertinas (sales a las $11 \mathrm{pm}$ ) o hasta guardias de todo un fin de semana. Los trabajadores de V\&S utilizan el tema del tiempo para demostrar su pertenencia al equipo. Entre más horas hayas trabajado en la semana, más demuestras tu amor por la hotelería. Es cuestión de jactancia personal en un sentido masoquista: "Te vas todo sudado y muerto".

Aquí se relaciona directamente con la experiencia. Los años en el ramo hotelero, implican mayor tiempo en esta lógica, lo que a su vez hace referencia a un mayor desgaste, desgaste que se ha logrado subsistir y entonces se jactan. La forma de jactarse, se expresa a través de quejas: "hasta me he regresado". Pero las quejas toman un sentido de honor. Aún en desacuerdo, lo hacen porque les gusta. El tiempo es para el trabajador de hotel como una marca de combate para el soldado. 
La hotelería determina la forma en que es vivido el tiempo en el grueso de la población. Un caso muy particular de esta zona turística es la homologación del horario dentro de la zona de Vallarta-Nayarit. El puente construido sobre el río Ameca entre Puerto Vallarta y Nuevo Vallarta si bien los fusiona como punto turístico, también tiene otra curiosidad: el horario. Apenas hace 5 años, los turistas y pobladores debían estar conscientes de la diferencia de horario entre ambas ciudades. Es decir, un turista debía contemplar que el Check-in y Checkout de su hotel en Nuevo Vallarta, iban una hora atrás a los horarios manejados en el aeropuerto. El río no tan sólo señalaba el límite político entre ambos estados, sino el punto donde el horario cambia, y no por sentidos geográficos (puesto que ambos corresponden al mismo meridiano), mas bien porque hace más de un siglo, Jalisco, por cuestiones comerciales, decidió homologarse al horario del centro (Ciudad de México) generando un desfase de una hora frente al horario del Pacífico (Nayarit) que le correspondía. En el 2007 se presentó la iniciativa que se hizo válida el 4 de abril del $2010^{12}$, donde el municipio de Bahía de Banderas, debido al vínculo comercial tan estrecho que tiene con Puerto Vallarta, adelantó su horario para ajustarse al de Jalisco. Eso hace de Bahía de Banderas, el único municipio de Nayarit con horario del centro del país.

"Era un rollo, y la verdad es que hasta lo usábamos de pretexto cuando llegábamos tarde (...) Solía quedar con mi novio en Nuevo Vallarta para salir, y me decía a las 5:00, yo le preguntaba ¿Qué horario, Vallarta o Nayarit? Y me reclamaba: ¿Pos' dónde vives? (...) Me causaba pena, pero es cierto. Somos coras y nos acostumbrábamos cada vez más a los usos de los vallartenses.

${ }^{12}$ Recuperado de NoticiasPV.COM (19 de marzo de 2010). 
Después no nos quedó de otra. (...) Fue un relajo, y podría decirse que era como haber cambiado al horario de verano dos veces seguidas, somos los únicos en Nayarit que tenemos este horario, todo por el turismo" (Trabajadora1, comunicación personal, 04 de junio 2013).

Esto puede verse como un ejemplo muy insustancial, pero es una evidencia de la influencia que tiene el turismo hasta en la magnitud básica de la medida del tiempo. La lógica de subordinación es retomada en otras esferas de la vida de un trabajador, el turismo es la prioridad; en las ciudades que componen la Rivera Nayarit, la población está acostumbrada a esta dinámica. La mayoría establece sus relaciones sociales y afectivas con personas del mismo giro y por ende, no es difícil ajustar la vida personal a la esfera laboral. Por lo tanto, esta percepción del tiempo no es sólo dentro de las actividades laborales, afecta el tiempo personal.

El tiempo en la recepción pasa suavemente entre las orejas en forma de brisa de aire acondicionado. Cuando le da sed, Trabajador8 se levanta al minibar y me pregunta: “¿Quiéres agua?, es lo único que te puedo ofrecer, la champagne es para los huéspedes y obviamente no podemos beber alcohol en horas laborales". Lo dice convencido pero un tanto esperando que yo le pida un poco y podamos beber a escondidas tan sólo un sorbo. Definitivamente, la carísima champagne enfriándose en el minibar es un pequeño aliciente para romper la rutina del día. Trabajador8 tiene 7 horas con 40 minutos laborales, los otro veinte minutos son para comer. Podría tardar un poco más, pero su espacio de trabajo tiene una ventaja que el comedor no: aire acondicionado y una silla tan cómoda 
que parece de despacho de abogado. "Estoy sentado la mayoría del tiempo, ¿te imaginas si la silla fuera pura madera?". Trabajador8 justifica su inactividad. Cada segundo sin hacer nada, implicaría improductividad; "supone una prioridad del trabajo sobre el ocio, basada en la consideración que el tiempo de trabajo es el único tiempo productivo o lucrativo posible" (Munné, 1980:58). Pero en este caso, es un descanso merecido designado por él mismo..

"Debía estar haciendo unos reportes y sacar la información para el corte, pero como ya salieron todas las personas y hoy no tengo llegadas temprano, ya me adelanté y acabé. Hoy no hay muchas llegadas, así es normalmente los martes. Bueno, por lo que sé. No hay mucho movimiento acá. Es un día más tranquilo y pues estamos más atentos a las llamadas internas que a los externas. Cuando tengo alguien apoyándome aquí, voy a darme una vuelta a la alberca, por si se necesita algo. Pero hoy no. Los huéspedes salieron de las instalaciones. Así que podemos aprovechar para platicar. Veniste un buen día. No me aburriré tanto" (Trabajador8, comunicación personal, 22 de mayo 2013). El rostro de Trabajador8 es nervioso y pensativo. La proyección que emana no es congruente con el gusto que dice tener por la compañía. Pareciera que Trabajador8 desea hacer algo más, algo que bajo la presencia de otros, no realizaría. ¿Acaso era la champagne que decía no poder beber? Veinte minutos después Trabajador8 deja entrever la razón de su singular hastío: "A veces vemos cosas por el internet". Trabajador8 confiesa que en los momentos de descarga, él puede atender otros asuntos ajenos al hotel. Lo importante es apurarse en todas las actividades pendientes. "No hay quejas si no dejas de hacer tu trabajo. Aunque nos tienen prohibido estar en el internet, la verdad es 
que ahorita no hay mucho que hacer para nosotros. Todo está limpio y ordenado". Trabajador8 no tiene grandes responsabilidades familiares, sin embargo sus amigos son una gran prioridad en este momento.

"Me gusta mi horario, me permite obtener un dinero cuando se necesita apoyo y aprendes más. Para poder llevártela tranquila, debes aprender más allá de tu departamento, así no te agarran de menso. Puedes determinar lo que es urgente y lo que puede esperar. Puedes dar un mejor servicio, y puedes desprenderte un poco más de esa sensación de que todo era para ayer. Al principio era muy pesado, me confundía, me sentía inútil. Debes recordar mil nombres, fechas de entrada y salida, costos, servicios, y eso que aquí [en V\&S] no hay lineamientos tan estrictos, porque en otros lugares hasta las palabras que debes utilizar para comunicarte con los huéspedes y tus compañeros de trabajo son muy específicas. Aún así, trabajar en un hotel puede significar una pérdida de vida social. Pero no, te acomodas. Trabajas horas extras, pides permisos, arreglas tus días vacacionales y solidarios, de manera en que puedes ver a tus amigos. Luego está bien cañón porque todos trabajamos en hoteles, pero pues te acostumbras.(...) Entre más tiempo estás en un hotel, más tiempo tienes para darte a ti(...), algunos hacen sus tareas de la escuela, otros escuchan música, yo a veces me pongo a planear mi fin de semana. Tal vez, lo que sí todos hacemos, es imaginar. Cuando hacía mis prácticas allá en Punta Mita, me tocó estar en división cuartos y recuerdo que me pidieron hacer el refresh de una habitación, osea revisarla por última vez que esté bien sin limpiarla a fondo. Recuerdo que me medio regañaron por tardar un poco más de lo debido. Pero te vas, hay una sensación en la que sólo estás tú haciendo tu chamba y nadie te molesta. Piensas en la familia, el trabajo, la novia, las deudas, tu día libre, los planes en la 
tarde, la escuela, tus planes de vida, no sé, en todo. Bueno, así es en todos lados, ¿no? Siempre estás pensando en todo y a la vez en nada. Como ahorita, platicamos y pensamos en las cosas que hemos hecho en nuestros antiguos trabajos. Como te digo, te ayuda a que el trabajo no te absorba. (...)Eso sí, si alguien te pregunta [refiriéndose a los compañeros de trabajo], estuvimos trabajando todo el rato [se ríe e imita una cara de harto y cansado], así es en la hotelería. Siempre estamos haciendo algo, y el descanso no es una opción. Todos lo hacemos, pero no todos lo saben(...) Sólo así puedes exigir que se te pague bien tu chamba" (Trabajador8, comunicación personal, 22 de mayo 2013).

Trabajador8 deja entrever la prioridad frente al uso del tiempo; un trabajador de hotel presenta el tiempo como un elemento que lo desgasta, lo cansa, pero que se aguanta. Y eso lo define como un mejor trabajador de hotelería, sin embargo el tiempo es una forma de legitimar "tu precio". El tiempo es una "moneda de cambio" que ofrece satisfacción económica y de recreación. Para los empleados de V\&S el tiempo aún es incierto en varias ocasiones, no tan sólo porque no tengan "hora de salida", sino porque la empresa no ha cubierto un ciclo de vida tal que les permita identificar todos los momentos altos y bajos de la organización. La dirección no se encuentra completamente identificada. Entonces el tiempo es ocupado para prospectar. Los trabajadores con más años en el ramo hotelero, usan su experiencia como ventaja para reconocer la capacidad de holgura entre sus actividades de rutina y las contingencias. Cuando alcanzan cierta proyección de la trayectoria del tiempo, se aventuran a organizarlo para sacarle provecho. Las camaristas pueden obtener más tiempo 
para reducir su presión, adelantando el trabajo o trabajando en equipo. Algunas veces los auxiliares de cocina se acreditan más trabajo, para ser los últimos en comer y poder quedarse más tiempo sentados. En oficinas administrativas organizan las actividades, para ir primero a comer y después, mientras la mayoría come, descansar un poco con las oficinas vacías. Cubrir más horas en el trabajo, porque la administración de su tiempo le ha permitido al Concierge estar las mismas horas sin que le haya significado mayor cansancio, le puede representar mayores ingresos.

El tiempo se vincula al final de cuentas con el rendimiento y la fatiga. El continuo diálogo entre trabajo y descanso -el no trabajo- (De la Garza, 2010:34). Más adelante se hablará de la riesgosa contraposición del trabajo frente al ocio, la libertad y la improductividad (Munné, 1980:58). Por el momento, es importante recalcar que en V\&S el tiempo en el trabajo implica paralelamente la administración de momentos que subsanen el desgaste físico y emocional que la presión continua del respeto al tiempo ajeno inyecta.

\subsection{ESCENARIO FÍSICO}

Para Hall (1972) el área física, lo que él llama espacio, es un referente de las interacciones a sostenerse dentro de éste. No existe una precisión de relación entre tipo de interacción y lugar. Pero, se profundiza en la capacidad de nuestros sentidos para, a través de los sentidos, percibir determinadas posiciones que incitarían conductas. El tiempo implica un espacio. Y la percepción de la distancia (Hall, 1972) permite dimensionar el tiempo. En todo caso, la distribución del escenario físico puede facilitar o limitar la interacción de los 
trabajadores del hotel. V\&S se localiza en la costa mexicana del Pacífico: la bahía de Banderas. Una de las bahías más bellas y profundas del mundo ${ }^{13}$. Cerca de su zona norte es dividida por el río Ameca que drena sus aguas del centro del país, y éste funciona como límite político de dos estados mexicanos. En esta limítrofe se encuentra el tercer puerto más importante y uno de los puntos turísticos más concurridos de México: Puerto Vallarta.

Su zona metropolitana está constituida por dos municipios, Bahía de Banderas y Puerto Vallarta pertenecientes a los estados de Nayarit y Jalisco, correspondientemente. A lo largo de esta zona se erigen numerosos desarrollos turísticos, que representan la actividad económica principal del área, V\&S es uno de ellos.

"Villas \& Spa es un territorio muy grande de tierra, donde hay muchos planes de crecimiento a corto, mediano y largo plazo. No todo será hotel. Hay una parte que es hotel, que es la que manejamos nosotros, hay otra parte de arriba que son terrenos de tiempo completo, compras tu terreno y construyes, o te ayudan a construir aquí, hay otra parte que será como un parque ecológico(...); a lo mejor hacemos un tipo club hípico, con caballerizas, equitación. Hay muchos planes en cuanto al global del terreno" (Gerente, comunicación personal, 27 de abril 2013).

V\&S mantiene su proyección como fraccionamiento residencial y actualmente se encuentra en constante rediseño para albergar los servicios necesarios en la operatividad hotelera. Dicha operatividad es la primera etapa en servicio (segundo semestre del 2012), puesto que consiste la forma de obtener el capital

${ }^{13}$ De acuerdo al Club de las Bahías más Bellas del Mundo (CLUB DES PLUS BELLES BAIES DU MONDE [s/f]) que tiene su sede en Francia, y el cual se ha constituido como una marca internacional de gran importancia para el sector turístico y del medio ambiente. 
necesario para reinvertir en las siguientes etapas del desarrollo e ir obteniendo utilidades a un corto plazo. Lo que está desarrollado ahora y lo que se está desarrollando (un condominio vertical) es la parte hotelera.

Sin embargo también existe la opción de tiempo completo: uno compra su casa o terreno, en caso de comprar terreno la desarrolladora te la puede construir y te cobra. Sea cual sea la opción se debe cuidar ciertos lineamientos de construcción y de diseño para que todo tenga una similitud.

Hacerse de un fractional o una casa propia en el desarrollo, no te separa del servicio hotelero que ofrece el desarrollo, por el contrario, para los trabajadores de este desarrollo, el fractional es el origen del hotel, así lo explica el Gerente del hotel:

“(...)nosotros estamos aquí a raíz de que lo que se vende es un fractional. Un fractional es un tiempo compartido, entonces la gente compra una semana, dos semanas, tres semanas; compran tiempo. Y la diferencia de un tiempo compartido normal a un fractional, es que se les escritura su porcentaje de dueño de esta propiedad. Entonces son dueños realmente, y a estos dueños se les vendió, una vez que obtuvieron su villa, darles un servicio. Ahí entramos nosotros" (Gerente, comunicación personal, 27 de abril 2013).

El fractional resulta la estrategia para continuar el proyecto como residencial, es decir con propietarios de villas y a la vez, mientras no están los propietarios ocupando su tiempo escriturado, se hace uso de las villas para rentarlas como hoteles. La propiedad del fractional tiene una validez de 100 años, por lo cual al estar escriturado se puede heredar. Esto lo hace más llamativo que los tiempos compartidos (los cuales son realmente una membresía), pues un fractional te 
hace dueño de la villa completa, por una fracción de tiempo. El resto del tiempo pertenece a otros dueños o al hotel para operarlo. De esta manera en V\&S se atiende tanto a propietarios como a huéspedes al mismo tiempo.

"Estos propietarios que ya compraron, llegan aquí que son propietarios, pagan su cuota de mantenimiento correspondiente al tiempo que van a estar y nosotros los atendemos en el inter; Si quieren que se les limpie la villa, darle información, consejería, mayordomo y ciertos servicios que hemos incluido a esta gente que ya son propietarios. Pero estos propietarios no ocupan todo el inventario que tenemos, entonces ahí entramos la parte ventas de hotel. En esta parte del hotel, tú haces tu reservación online, a través de agencia de viajes y vienes y te hospedas en el hotel. Entonces son éstas dos: propietarios por un lado y huéspedes hoteleros por otro. Nosotros le damos servicio a todo mundo. Así está constituido Villas \& Spa" (Gerente, comunicación personal, 27 de abril 2013).

V\&S al día de hoy cuenta con diecisiete llaves (así se le denomina al número de villas que tienes en disposición para rentar como hotel). Estas 17 llaves están a su vez divididas en tres diferentes tipos: Diamante, Jade y Esmeralda.

Cada villa, dependiendo del tipo, cuenta con diferentes servicios y comodidades para la estancia de los huéspedes y propietarios. Varían en el número de habitaciones, el diseño interior y el equipamiento. Todas cuentan con comodidades tales como cocina integral, sala, comedor, alberca o jacuzzi privado, terraza, aparatos electrodomésticos, estudio y equipo de lavandería.

Las villas están a cargo de Ama de Llaves. Ella tiene dos semanas que se le ha proporcionado una nueva oficina. El lugar asignado es un tráiler de oficinas, 
ubicado en el estacionamiento del personal, escondido entre la flora a las afueras del hotel. Llegamos en un carrito de golf que levantaba la tierra cual tormenta de arena. El sudor del viaje cesaba con el aire acondicionado que soplaba dentro del tráiler. Al entrar se apena:

"Esas cajas no van ahí, pero los de Spa aún no tienen terminada su área, (...) Así empezamos todos, yo antes no tenía un lugar (...) me han cambiado de acuerdo a como va creciendo [el hotel]. Ahora me dejaron este lugar para mi sola y pues ya quepo(...) Para la ropería ocupamos un lock-off, hasta que terminen de construirnos nuestra área" (Ama de Llaves, comunicación personal, 13 de junio 2013).

Un lock-off es una habitación específica que tienen todas las villas, ésta cuenta con los elementos necesarios para utilizarse como una villa independiente. Comparte una puerta con la villa principal, pero si se necesita, la puerta se cierra con seguro y se ocupan como dos villas distintas. Los lock-off son la mejor oportunidad de incrementar la capacidad del hotel, por lo cual sólo uno se ocupa para almacenar todos los blancos y amenidades que utilizan en V\&S. La decisión de almacenar en una habitación, a falta de una Ropería, mas allá de la ubicación y la amplitud del espacio, es por la instalación del aire acondicionado, necesario para algunos químicos que almacenan las camaristas y camaristos. V\&S sigue en construcción y las áreas de trabajo de todo el personal se van redistribuyendo conforme el proyecto crece.

En un principio iban a ser villas, un desarrollo residencial de lujo. En el momento en que se decidió la operación tipo fractionals y hotelera, los planos de construcción tuvieron que adaptarse. Un espacio de oficina para ventas, ya no 
sería suficiente. El área administrativa del hotel tuvo que iniciar como todos los demás departamentos, en tráileres.

"Se rentaron tráilers como los de nosotros [la constructora] y tal cual, veías a la gente formada en el monte, esperando ser entrevistada por RRHH. Pensamos que no aguantarían, pero parece que se acostumbran a todo(...) Tan pronto se termina un área, se les entrega a los del Hotel para que la empiecen a trabajar. Poco a poco se han ido haciendo de sus espacios. Son medio exigentes" (Constructora, comunicación personal, 18 de junio 2013).

La visita de los jefes: el Director General (DG), el Coordinador General (CG) y el Director de la Operadora del Hotel (DOH), son claramente importantes para el equipo de Villas \& Spa. Ellos se presentan cada que se entrega una nueva área en el hotel. En este caso fue el Spa. Se dice que se "entrega", cuando la constructora termina su trabajo en cierta área y la presenta ante la Jefatura a cargo (Hotel, Restaurante, Spa, Ventas...), la gerente de Spa en este caso, tuvo que hacer un check-list de todo el inventario que se le entregaba a ella y firmar de conformidad con lo cedido. En caso de tener desperfectos de obra o mantenimiento, la firma (jefatura) no se hace responsable hasta que quede completamente terminado. Una vez recibido, toda la responsabilidad corre a nombre de la gerente de Spa. Para la visita de los jefes, la gerente de Spa ya había inventariado y autorizado. Termino de contratar el personal requerido y ajusto detalles de uniformes, blancos y productos a utilizar.

"Es como mi graduación [se burla]. No, en serio. Digo cada proyecto nuevo viene con sus propios retos. Es mi carta de presentación con los del hotel. Que se den cuenta de lo que soy capaz. Uno se vende de cierta forma, pero hasta que ven lo 
que logras, se dan cuenta de lo que vale, lo que cuesta, de quién es uno, ¡vaya! Si el huésped sale sonriente, cumplí con mi propósito." (Gerente de Spa, comunicación personal, 18 de junio 2013).

DG, CG y DOH presenciaron la entrega de las instalaciones del Spa y se les hizo de su conocimiento el estado de capacitación en el que estaba el nuevo personal y los servicios con los que se contaban en esta área del hotel. Se ajustaron detalles, se hicieron comentarios oportunos y se le dio luz verde a la gerencia del Spa para iniciar operaciones.

“(...)Y pues sí estuvo dificil, es un proyecto muy distinto a lo que hay en la región. Ya tengo dieciocho años en esto y no todo mundo te arma un concepto. El concepto de un spa es básico. Ahora que vengan nuestros invitados VIP, y cualquiera de nuestros huéspedes, podrán darse cuenta de que todo servicio tiene un trasfondo coherente con el concepto. Estoy haciendo un producto que no sólo les va a dejar mucho a V\&S, sino que me ofrece una oportunidad de vida, en mi vida profesional. Me están dando toda la confianza para tomar mis decisiones, eso no te lo da cualquiera, ahora les voy a demostrar que hice con esa confianza." (Gerente de Spa, comunicación personal, 18 de junio 2013).

Los primeros clientes, después de haber hechos las debidas pruebas de los productos con el personal del hotel, fueron la esposa y amigos del DG, invitados a V\&S específicamente para la inauguración del Spa.

Continuando con Goffman (1959:11), se presentan dos públicos en quién los trabajadores deben centrarse en esta ocasión especial. "Si tomamos un determinado participante y su actuación como punto básico de referencia, podemos referirnos a aquéllos que contribuyen con otras actuaciones como la 
audiencia, los observadores o los coparticipantes". Su desempeño, actitud y participación frente al equipo definirá o legitimará su rol dentro del hotel frente a estas audiencias; "(...)cada uno de estos diferentes papeles puede ser presentado por el actuante en una serie de ocasiones ante los mismos tipos de audiencia o ante una audiencia compuesta por las mismas personas" (Goffman, 1959:11). Para la gerente de Spa, era su manera de avalar el cargo. Y el comportamiento ejercido sería esencial para ofrecer una apariencia (performance) segura, eficiente, autoritaria y empática que pudiera ser percibida por su audiencia.

El performance entonces muestra en todo su esplendor ese doble rol que se juega constantemente entre los trabajadores de V\&S. Un rol para influir en la impresión del dueño, similar al encarnado frente a un huésped VIP y otro para demostrar la vocación frente a los compañeros de trabajo y hacerse de una marca de guerra más.

Si para la audiencia es congruente este comportamiento durante la visita, la autoridad como gerencia estaría establecida frente al equipo de trabajo, lo que facilitaría sus interacciones dentro del hotel. Ya Goffman(1959:8) ha tratado el tema de la primera impresión en los trabajos de empresas de servicios, donde es más fácil establecer "la línea de trabajo" que se adoptará frente a la audiencia desde un principio, que cuando se ha iniciado la marcha. Por eso tan importante, la primera impresión. En el caso de la Ama de Llaves y su equipo de trabajo, no es la primera visita del dueño, y la atención estaba ahora en los detalles. Reforzar la primera impresión dada con anterioridad, darle seguimiento. El 
cuidado se aplica en las especificaciones que identificaron como gustos y quejas, el dueño y su familia, en las estancias pasadas. Ellos conocen las expectativas que tiene el DG al abrir su villa, y es el deber de Ama de Llaves de cubrirlas. Expectativas que también resultan de sus prioridades; y que pueden ser muy distintas a las del CG y DOH. Todas deben ser cubiertas, por muy diversas que sean. En las villas, como en la actitud de su equipo de trabajo.

Realmente la "marcha forzada" no implicaba mayor trabajo, sino mayor cautela. La línea del performance ya fue establecida anteriormente, y el rol se centra en recordarlo y reproducirlo. Así es con cada huésped. En la medida en que un huésped se hace cliente del lugar por la frecuencia de visitas, el personal de contacto del hotel está comprometido a reproducir la experiencia de la estancia anterior en la mayor medida de lo posible. El dominio del trabajador sobre su área física de trabajo es esencial. ¿Cómo dominar el área física si ésta es redistribuida constantemente?

Bien, la respuesta es clara. La experiencia no debe ser igual, en el caso de V\&S, sino mejor. Puesto que la redistribución es una respuesta al crecimiento del proyecto. El hotel va obteniendo mayores áreas de trabajo y así, un mayor compromiso de calidad en su trabajo: en su logística. Los trabajadores deben reproducir en su comportamiento esas mejoras físicas del hotel. Debe notarse en su trabajo, en su actitud, en su imagen, que las mejoras de las áreas han producido cambios benéficos en la totalidad del hotel. De tal forma, logramos una diferenciación más explícita del espacio en sentido performativo y un área física. El espacio no es sólo un contenedor -un área física-, es la incorporación 
de distintos elementos en el actuar diario de las personas (Lefebvre, 1991 en Beyes y Steyaert, 2011:49), -producción y evolución-.

Como empresa de servicio, V\&S es un desarrollo cuyo servicio principal -el fractional- se basa en la compra-venta de tiempo. Esto sitúa al hotel como un espacio cuyo actuar está rendido plenamente al juicio de la importancia del tiempo. Como en el apartado anterior, el tiempo para V\&S no sólo implica una moneda de cambio de manera interna, sino externa. La hotelería, como los fractionals, ofrecen al huésped un periodo de tiempo, en un espacio de exquisitas comodidades, por una remuneración económica. Cada segundo del huésped en las instalaciones de V\&S ha sido pagado. Por lo tanto, a diferencia de otras organizaciones, el tiempo del trabajador, mientras se ubica en las instalaciones está supeditado al tiempo del huésped. De manera muy general, el segundo rentó al primero; y el escenario físico delimita el alcance de su gerencia. El espacio, no sólo refiere una función (Hall, 1972) sino un rol, y esta lógica de interacciones viene implícita en el contexto del propio espacio (Scheflen en Winkin, 1984).

\subsection{CONTEXTUALIZACIÓN}

El espacio-tiempo al ser un referente, dirige el sentido de los actos que se presentan, eso sí, bajo un contexto lleno de significados que le dota de congruencia (Goffman, 1959). Contextualizar a V\&S remitiría a situarla en su etapa de planeación en el año 2003, momento en que se compraron las primeras propiedades en el área de la Cruz de Huanacaxtle, a partir de la 
inversión de un empresario consolidado en la ciudad de Monterrey, Nuevo León. Con respaldo de sus agencias automotrices, incursionó en lo que en principio serían las Bienes Raíces. Se crea una primera figura comercial para contratar los servicios de una constructora, quien levanta las villas y el total del desarrollo. Así mismo vende las villas a una segunda figura comercial encargada de cerrar los contratos con los extranjeros estadounidenses y canadienses, que representan el mercado principal del desarrollo.

En los primeros meses del proyecto, la venta resulta un proceso difícil y de lenta liquidez, por la situación ya antes mencionada que se estaba viviendo en la zona turística de Bahía de Banderas, que alerta a su principal inversionista de un posible fracaso. Asesorado por un amigo, el dueño decide dirigir su inversión al campo de los fractionals, donde paralelamente se pudieran aprovechar las villas construidas, como hotel, naciendo así una figura encargada de la operación del desarrollo: Villas \& Spa (V\&S).

V\&S a su vez contrata los servicios de una marca posicionada internacionalmente, quien se especializa en la asesoría, diseño y administración de espacios lujosos residenciales y hoteleros amigables con el ecosistema, y que para este caso en específico presta sus servicios sólo como administradora y asesora de la parte hotelera del desarrollo.

Scheflen (en Winkin, 1984:152) en la teorización sobre el comportamiento de los individuos, al tratar el punto de dónde se sitúan estos comportamientos y vínculos, si bien no menciona específicamente al espacio, si desarrolla la noción 
de los "contextos" ${ }^{14 " ~(d e n t r o ~ d e ~ s u s ~ p r e m i s a s) ~ c o m o ~ l a s ~ s i t u a c i o n e s ~ p a r t i c u l a r e s ~}$ donde serán suscitadas o "descencadenadas" específico tipo de interacciones.

Para Scheflen, la ocasión es un tipo de contexto que puede darse de acuerdo a periodos sociales. En este caso un evento fue contundente como referente en los habitantes de esta región turística, y que enmarca un periodo de fuerte desarrollo para la zona a partir de la renovación de esfuerzos de los estados vecinos; El 31 de mayo del 2013, de acuerdo con el programa presentado por la Secretaría de Turismo $(\text { Sectur })^{15}$, la zona de Vallarta-Nayarit fue inyectada con una inversión mayor a 10mdd para promocionarla internacionalmente a través de televisión, radio, internet y medios impresos. La titular de la Sectur, Claudia Ruiz Massieu, considera que Vallarta-Nayarit cuenta con un turismo en común que no distingue entre ambos estados que lo componen. Esto debido en gran parte, a que comparten un mismo aeropuerto internacional (Puerto Vallarta) construido a un lado del límite entre los dos estados y que tanto pobladores, trabajadores como turistas se despliegan a través de esta parte de la bahía, cruzando el río Ameca sin algún tipo de complicación o sobre aviso.

Su relación en el tema del turismo, tuvo un fuerte crecimiento en los 70's cuando las playas de Puerto Vallarta fueron redescubiertas por los ojos extranjeros, a partir de la construcción del aeropuerto internacional, la subestación eléctrica de

\footnotetext{
${ }^{14} \mathrm{Al}$ menos cuatro contextos son evidentes para Scheflen (en Winkin, 1984:152):

"El marco físico. Por ejemplo, los funerales en nuestra cultura se desarrollan en privado o en centros funerarios. El marco, los ornamentos y otros factores físicos están establecidos por la costumbre.

"La ocasión. Los programas pueden limitarse a determinados momentos del día, el mes o el año, o producirse con ocasión de periodos sociales o cosmológicos particulares. La fecha de la Pascua, por ejemplo, se establece en función de las fases de la luna y el equinoccio de primavera.

"La estructura social. Es posible que el programa se produzca solamente en el seno de grupos de una composición dada, y que a su vez el programa realizado determine las relaciones mutuas.

"La estructura cultural. Los programas no son más que unidades en la cultura que los engloba, y se producen en relación temporal y espacial con otros programas".

15 Recuperado de JALISCO Gobierno del Estado (31 de mayo de 2013).
} 
la CFE, el puente sobre el río Ameca, entre otros, inaugurados durante la visita del presidente estadounidense Nixon a México en agosto de 1970. Desde entonces la necesidad de más playas para fomentar el flujo de turistas promovieron el desarrollo de un destacable número de hoteles en lo que se denominó Nuevo Vallarta (a las afueras del pueblo de Puerto Vallarta y cerca del aeropuerto, colocándolo fuera de territorio jalisciense). Los hoteles fueron diseñados para un turismo internacional con programas All Inclusive (Todo incluido) y Tiempos Compartidos. Nuevo Vallarta inició así, como el conducto para que el crecimiento de infraestructura inyectada a la playa jalisciense se distribuyera hacia el norte a territorio de Nayarit, dando auge a las otras ciudades que conforman la Riviera Nayarit; Éstas crecieron como puntos de descanso, recreación acuática y de actividades ecoturísticas.

Puerto Vallarta se estableció entonces como el pueblo (ciudad) principal que ofrece al turista la vida nocturna, espacios recreativos y de vínculo cultural con los aldeanos. Nutriendo a las otras ciudades, a partir de su puerto marítimo, aeropuerto y vías terrestres.

El contexto de Scheflen (en Winkin, 1984), es similar a la concepción -limitadadel espacio de Hall (1972) en cuanto a que se presenta como un referente que dota de sentido a las interacciones -actos-. Pero ofrece elementos que profundizan en la revelación de estos referentes. El autor deja entrever la apreciación de la multiplicidad dentro del contexto de la estructura cultural; los programas -es decir, específico tipo de interacciones- se relacionan con otros, 
produciéndose de manera conjunta.

En otras palabras, no es un solo contexto, sino diversos, que interactúan entre sí y producen una lógica específica que incide en el espacio. En el caso de V\&S, su participación dentro de una específica zona turística influye en la performación de sus propios trabajadores: Vallarta-Nayarit no es sólo una marca de promoción, sino una magnitud que nos denuncia un momento, evoca una distancia entre un punto y otro: el pasado y el hoy, el hoy y el futuro. Esta distancia, coloca y ordena los sucesos en la mente de las personas. La Zona Metropolitana de Vallarta-Nayarit desarrolló su lógica de vida, entorno al turismo, pero también en torno a una dinámica de competencia entre estos estados. Es una convergencia entre la necesidad de destacar fortaleciendo una identidad propia y continuar con la tradición del ramo turístico. La educación, las relaciones familiares, sociales y laborales, se ven continuamente incididas por estos referentes. La transitoriedad de esta realidad es una característica básica de la temporalidad. El turismo no es sólo un sector, es una lógica de percepción del tiempo.

En un inicio Vallarta fue símbolo de prosperidad, el auge que tuvo la zona de Rivera Nayarit, debe su éxito a la fidelidad que tuvo la población de esa zona al ramo turístico. Todas las estrategias de crecimiento de los poblados circunvecinos se sometieron a las promesas del sector. El ritmo de vida de las familias se acoplaban a las temporadas altas y bajas de los visitantes. Puerto Vallarta era la prueba fehaciente que el turismo dotaba de un flujo de dinero abrumador al ancho de la población local. 
"Mi madre era camarista, cuando se embarazó de mí dejo de trabajar porque ya éramos tres en la casa, pero mi papá no. Él nos mantuvo un buen rato, hasta que mi hermano empezó a trabajar. Los dos eran bell-boys. Yo crecí con la idea de vivir aquí, me gusta mucho Bucerías, y para vivir aquí o le entras al servicio, o ya. ¡No hay de otra! Digo, puedes trabajar en otros lugares que no sea un hotel, pero todo aquí está fuertemente relacionado a la hotelería (...) Mi madre fue la que me motivó a estudiar. ¿Y que iba a estudiar, sino turismo? Tan pronto termine mi carrera, yo ya tendré año y medio trabajando en el hotel, y podré solicitar un mejor puesto. Sigo viviendo con mis padres, casi nunca los veo, pero ellos entienden como es esto de la hotelería. Nunca hay tiempo para otras cosas, sólo para el servicio. (...) ¿Vacaciones?, pues con los días solidarios en temporada baja. (...) Así también va a ser cuando yo tenga hijos, ellos podrán estudiar y trabajar en lo que ellos quieran, pero si quieren quedarse a vivir aquí, la hotelería es lo más seguro. Creo que nunca dudé lo que quería hacer de grande. Creo que nunca hubo otra opción [se ríe], y lo disfruto. Yo no entendía a mis padres tanto amor que le tenían a su trabajo, hasta que yo entré a mi primer hotel." (Trabajador4, comunicación personal, 03 de julio 2013).

Trabajador4 no ha dejado de sonreír, es claro que hay un orgullo por su trabajo, que desea heredar a la siguiente generación. V\&S no sólo implica un lugar donde externalizar el valor que le da a su trabajo, sino el valor de un linaje. Para los trabajadores de este hotel, laborar desde esta etapa inicial del proyecto, les permite absorber con mayor facilidad ese cúmulo de significados que abarca el contexto del hotel y mezclarlos con los suyos. Trabajador4 con base en la experiencia de su linaje experiencia, aporta una semilla al proyecto que inicia, lo que representa no tan sólo una mayor seguridad de que va por un buen camino, 
puesto que él es parte de la operación; pero también se salpica de un sentimiento más íntimo, por hacer de V\&S un proyecto personal. Su próxima licenciatura es la garantía que su familia está mejorando. Y el crecimiento del hotel es la manera de demostrarle a su familia que su trabajo ha dado frutos, y por ende que él también es de la hotelería. Como el área hotelera de V\&S se ha ido fortaleciendo a tal grado de poner en segundo lugar la venta de fractionals, el hotel se considera un éxito, y es un éxito compartido con sus trabajadores. Trabajador4 comenta mientras nos acercamos a una villa, que él no desea estar todo el tiempo como camaristo, pero que siempre hay que iniciar de abajo. El trabajo influye en la esfera social y viceversa, el vínculo es una respuesta a los diferentes hechos históricos (De la Garza, 2010; Neffa, 2010). Apenas tiene seis meses en este hotel y considera que su desempeño y escolaridad le permitirán crecer junto con la empresa.

\subsection{CONTINUIDAD}

A punto de responderme en qué puesto le gustaría desempeñarse más adelante, Trabajador4 emite lentamente una sonrisa que culmina en una muestra exagerada de su dentadura y ojos, pareciera que ni parpadeara. Dirige mi mirada a un huésped que iba varios pasos atrás de nosotros y que al detenernos en la puerta, logra alcanzarnos para entrar en la misma villa que nosotros. "Buenos días, Señor. ¿Podemos entrar a hacer la limpieza o gusta que pase más tarde?..." 
Como ya se mencionó, el Spacing Organization implica ver a la organización como una multiplicidad de espacios. Cada espacio responde a una lógica en específico, que interactúa con otros espacios -otras lógicas- dentro de una misma organización. Trabajador4 está entrando a otra lógica de manera paralela cuando percibe la cercanía del huésped. No deja de lado sus pensamientos para atender al huésped. Cada acción va cargada con un sentido personal. Su rol como camaristo frente al huésped, no sólo implica una función, sino unos intereses que comulgan o discrepan con su actitud de servicio. Para cada audiencia, existe una lógica de interacción. Esto se profundizará más adelante, en el reconocimiento de la multiplicidad de espacios, en el capítulo 4. Por el momento, se destaca una latencia de los demás espacios en el mismo momento que Trabajador4 camina por el hotel. Latentes, porque están ahí esperando a ser retomados por Trabajador4 de acuerdo a las interacciones con los otros actores en V\&S. No se suprimen unos por otros, por el contrario, interactúan entre sí.

Trabajador4 se ha permitido conversar y "estirar" lo más posible el tiempo libre entre sus actividades para relajarse y dar respuestas a lo que se le cuestiona. No es algo que haga comúnmente, y se le nota el gusto del interés que puede generar su opinión. $Y$ aún con esa holgura de tiempo que se ha permitido, no deja de hacer sus actividades. En el momento en que se ubica frente a un huésped, no hace un cambio abrupto de su conducta. Trabajador4 se desliza entre sus públicos de manera sutil, si pareciera que interrumpe una acción, entonces podría suponerse que hay algo malo, que la actitud de Trabajador4 frente al huésped, u otro actor, es falsa, forzada o fingida. Trabajador4 hace uso 
de la continuidad de sus gestos y actitudes para mantener una idealización de su actuar (Goffman, 1959:37). "Después de esto, un café. Tengo que mandar por correo las fotos que tomé en la mañana. Son reportes sobre el estado del hotel, y estos llegan a manos directas del gerente. En lo que se envían, nos preparamos el café". Mientras sus decisiones no afecten la coordinación, el es dueño de su tiempo. Al menos así lo siente, por pequeños lapsos del día.

Munné (1980:57) ofrece un panorama amplio sobre las grandes tendencias en el estudio del tiempo libre. La diferenciación entre el trabajo y el ocio es un rasgo característico de la sociedad industrial, que también ha sido analizado bajo un lente holístico, afirmando una "interdependencia relativa entre ambos tipos de actividad humana". Sin embargo, lo común es que "(...)ocio y trabajo aparecen como dos polos opuestos" (1980:58). Cuando uno se encuentra en una actividad laboral, se encuentra ocupado y por lo tanto no está ocioso.

Como se mencionó, la hotelería enseña el respeto al tiempo del otro: "Todos tenemos cosas que hacer". La coordinación es una organización de los tiempos en conjunto. Los esfuerzos son colectivos y el tiempo es entonces compartido. Eso fortalece el compromiso en el trabajo en equipo. Sensibiliza a los trabajadores en la participación de los proyectos y los dota de cierta autonomía. En V\&S, las situaciones y problemas contingentes, son "el pan de cada día" de acuerdo con un trabajador del hotel. Atender la situación lo antes posible y "de buena forma" son las directrices fundamentales del quehacer diario.

"Siempre surge algo. Eso me gusta de este trabajo. Nunca es igual. Siempre hay un problema nuevo. No te aburres. Es el pan de cada día y no te puedes quejar, las cosas se hacen bien y de buena forma. No hay de otra. ¿El huésped qué 
culpa tiene de tus rollos? ¡Así es!" (Trabajador1, comunicación personal, 03 de junio 2013).

Sin embargo, aunque las contingencias sean una cotidianeidad, la cantidad de tiempo dedicada a éstas varía de acuerdo a la temporada. En V\&S existen temporadas altas y bajas. $\mathrm{Y}$ las actividades a realizar en estas distintas temporadas, varían en gran medida por la ocupación del hotel. Un trabajador administra sus días de la misma forma. Hay días altos y días bajos. Hay horas altas y horas bajas. El punto es nunca interrumpir la continuidad del servicio. Si un camaristo o un recepcionista va a darse un "tiempo personal", debe ser en la holgura que sus horas altas y horas bajas lo permiten.

Así lo expresan las formulaciones centradas en la cooperación y la anulación del trabajo (como relaciones de producción): “...trabajar menos para vivir más” (Gorz, 1980, citado en De la Garza, 2010:28). Esta diferenciación entre dos mundos, el del trabajo y el no-trabajo, implica el control de ambos para no mezclarlos y evitar así agentes externos que pudieran frenar la dinámica de cada uno de ellos. En uno, se supondría la no-libertad y la carencia simbólica de vida; en otro se enfatiza la capacidad de toma de decisión, la oportunidad de disfrutar y recrearse, pero también la tendencia a desperdiciar el tiempo (ocio).

El control del tiempo implica a su vez un control del espacio; un estrés laboral que condiciona la felicidad del trabajador, pero sobre todo, una apropiación de la libertad del ser humano. Se reduce o manipula su espacio-tiempo libre y se coarta su autonomía. 
Pero, ¿para obtener uno hay que negar el otro? Es claro que la fórmula económica bajo la que vivimos determina las relaciones estrechadas a nuestro alrededor y plantea las reglas del juego. El espacio-tiempo se subordina al trabajo; pero el horizonte plantea una "nueva construcción social de los límites entre el trabajo y el no trabajo, flexible, rearticulable en parte en función de prácticas"; De la Garza (2010:34) coincide en este punto con la concepción de Montaño y Rendón (2000) donde la organización no es vivida sólo como un trabajo, es sujeta a múltiples reinterpretaciones de quienes participan en ella.

"Es mi segunda casa" dice Trabajador8, sube las piernas al escritorio y las vuelve a bajar con pena “¡No, no es cierto!”. Se apena, pero no deja de reírse de su arrebato. Trabajador8 cuenta con una facilidad de conversación. A diferencia de Trabajador4, Trabajador8 tiene un trabajo menos extenuante en lo que se refiere a esfuerzo físico y resistencia al sol. Sin embargo en ambos existe una presión constante por trabajar las horas que el servicio necesite. Munné (1980) se preguntaba como parte de su propio análisis, si bajo esta contraposición del trabajo-ocio, todo lo que no es trabajo ¿realmente es improductivo para la empresa?

Para Trabajador8, la continuidad no implica sólo un seguimiento de sus actividades laborales; la continuidad también se sitúa en los otros aspectos que integran su persona. Trabajador8 busca la continuidad de un espacio personal dentro del trabajo, haciendo alusión a la sensación de "segunda casa". Hay un interés por dotar al trabajo de una emoción de comodidad, familiaridad y gusto. 
La continuidad se encuentra también en la confianza con que realiza sus diversas actividades dentro de V\&S, no importando si son o no consideradas "trabajo". Los trabajadores de V\&S evitan subordinar el ocio frente al trabajo, bajo la suposición de que no todo lo que no es trabajo es ocio. En el espaciotiempo del trabajo y del no-trabajo se encuentran elementos que complementan el acto social de la propia organización. Es una temporalidad multiespacial que constituye complementariamente la realidad organizacional.

Para Trabajador4, una taza de café no implica ocio. Es un gusto, que a su vez supone le ofrece mayor capacidad para mantenerse despierto en un día pesado de trabajo. El no-trabajo implican actividades que circunciden a las actividades laborales y que de forma indirecta se relacionan con las actividades del hotel. La presión continua dentro de las actividades hoteleras, obligan al trabajador a romper con una conducta (servicial) sin cortar la continuidad del escenario performado. No se puede estar trabajando todo el tiempo, pero ni el huésped, ni todos tus compañeros de trabajo deben darse cuenta. El performance de los trabajadores de V\&S supone un continuo ritmo de trabajo sincronizado y atento a las contingencias del servicio al huésped; la atención de otros temas o ritmos en el escenario laboral, implican de una habilidad. La administración del tiempo se vuelve un "arte", que se aprende con la experiencia, es decir, con más tiempo. 


\section{CAPÍTULO 3}

Performance:

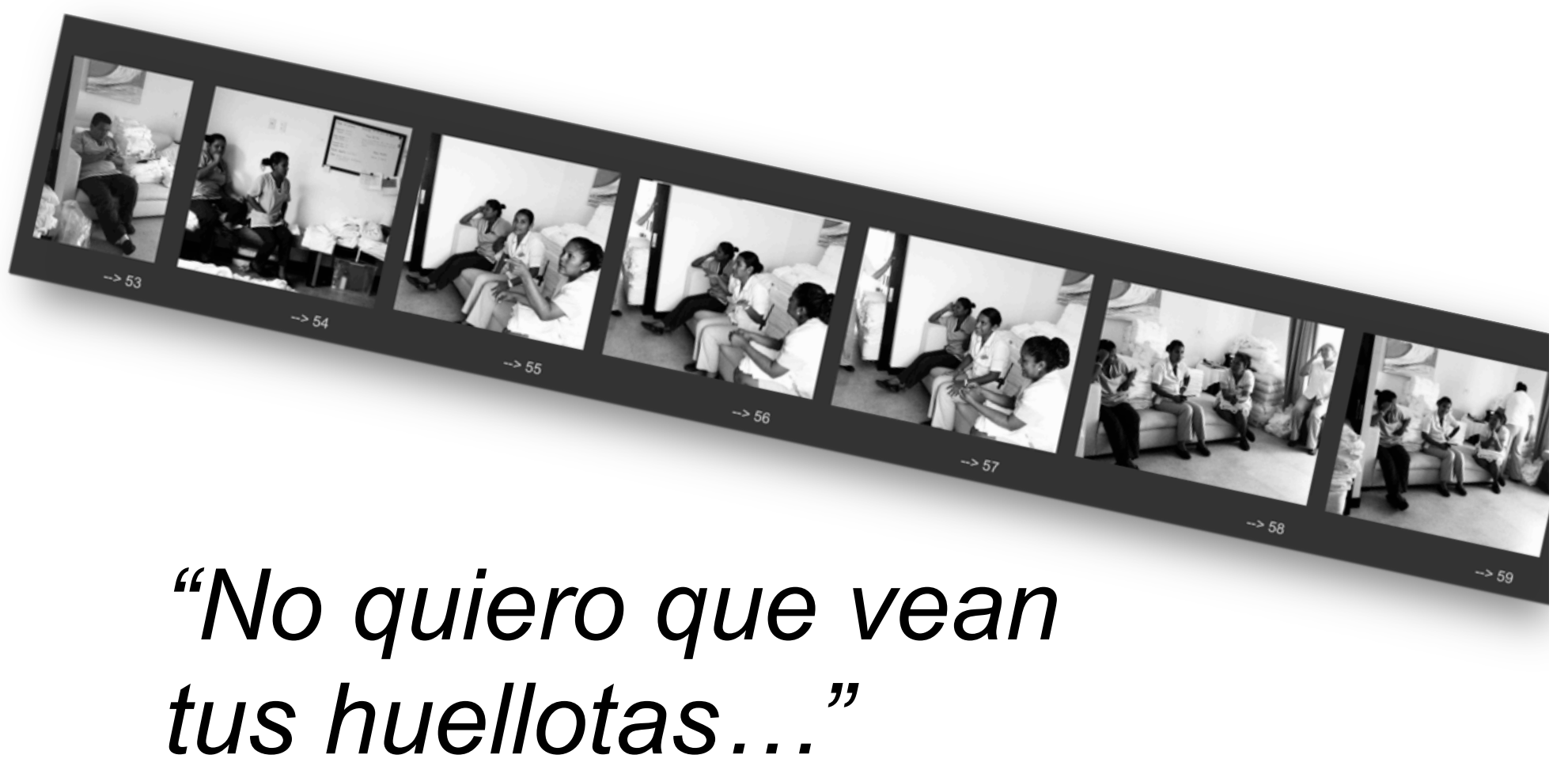




\section{CAPITULO 3. PERFORMANCE}

"Think of space as a verb, not a noun"

(Beyes y Steyaert, 2011:56).

"Esta semana todo mundo trabaja a marcha forzada", lo dice con una sonrisa de complicidad frente a sus compañeros de departamento. Todos saben a qué se refiere: los jefes están en casa (en el hotel). Ama de Llaves sale del briefing y tiene un aire de nerviosismo salpicado en los ojos, no parece estar incómoda, sólo nerviosa, como entusiasmada por las actividades de los próximos días.

Son casi las diez de la mañana, en el briefing se les ha dado un resumen del status y los huéspedes que esperan para ese día y los próximos. Un huésped puede ser el origen de una serie de actividades que no se realizarían del mismo modo en la cotidianeidad. Tanto el modo como las actividades en sí, figuran en la performación del espacio de V\&S.

Un performance sin errores es el objetivo. Ama de Llaves no lo dice con esas palabras, pero su necesidad de confirmar que hasta el más mínimo detalle esté en su lugar, lo expone por ella. Apresura el paso, se ventila con unas hojas que lleva en la mano y me invita a seguirle. Subiendo unas escaleras, un trabajador de su área se encuentra tomando fotos de desperfectos en las áreas públicas. Ama de llaves le pregunta: ¿Sí tenemos ya listas las villas VIP, verdad? Trabajador4 no afirma, está a punto de responderle sobre algunos detalles cuando un huésped se acerca; Mismo ritual: sutilmente guardamos silencio, sonreímos y Trabajador4 saluda con un tono contrastado, es dulce, pero a la vez 
firme. Ninguno de los presentes ha hecho consciencia de lo que está sucediendo, sólo reaccionamos para aparentar orden y calma. Sin embargo, todo este recorrido ha sido la descripción de una parte del performance de los trabajadores del hotel.

En el espacio, hablar de performance y performativo como términos similares, no es del todo correcto, aunque sustentados en la misma cualidad que la acción de performar ${ }^{16}$, para adentrarnos en la categoría de performance, es importante hacer una diferenciación.

Un concepto performativo es una forma distinta de ver las cosas que ya existen; permite analizar al espacio, como un conjunto de elementos que lo van encarnando, a partir de sus interacciones realizadas día a día. Hablamos del espacio del hotel como el conjunto de un número grande de actos que relacionados entre sí, a partir de ciertas lógicas, participan en la encarnación de una dinámica en particular. No es ver a detalle, sino mas bien, atender que es un trayecto continuo de miniactos ${ }^{17}$.

El hotel puede ser o no ser visto como un Spacing. Si se ve como escena concreta, se observaría a un huésped que saluda a Trabajador4; si se ve de manera performativa, en la misma escena se observarían una serie de actos: el huésped levanta la mano al saludar, gesticula, espera atento a las facciones de

\footnotetext{
${ }^{16}$ Ya anteriormente se mencionó que performar como acción, refiere a una cualidad específica de esta palabra como creadora de la realidad concreta a partir de la acción misma.

${ }_{17}$ Para ejemplificar, Beyes y Steyaert (2011) hacen referencia al caso del slow motion. El slow motion toma una escena (un video de pocos segundos) de la vida cotidiana y la subdivide en un variado número de fotografías (como un rollo de película). Un segundo es percibido a mayor detalle a partir del gran número de fotos que lo conforman. Lo que parece un movimiento, gesto o acto rápido y poco perceptible, recibe particular importancia al visualizarse a detalle el trayecto que cubrió de un punto a otro, a partir de las fotos. Los autores presentan la concepción del espacio como el constructo de una serie de partículas (miniactos) que, vistos en semejanza al slow motion, permiten ser observados, como un gran número de fotos que integran a un solo espacio.
} 
Trabajador4, el sol se refleja sobre sus lentes obscuros que lo dotan de anonimato pero a la vez de un papel estelar al caminar por el hotel, de manera paralela Trabajador4 es desconcentrado, el sol abruma su cuerpo, se reprime por ser interrumpido en su ritmo de trabajo, esconde la cámara fotográfica, sonríe (tal vez forzadamente), espera alguna orden del huésped, intenta adivinar sus intenciones, se sabe evaluado por el Ama de Llaves, entra en ansia por querer continuar con su actividad sin parecer descortés, responde con alguna bienvenida o saludo, y así sucesivamente. El espacio performativo se presenta como un resultado de la práctica encarnada, vivida e incorporada en una red de instantes: un continuo vínculo entre estos instantes.

No hay una consciencia tal de Trabajador4 sobre esta forma de concebir el espacio, ni siquiera el huésped está atendiendo pausadamente cada uno de estos detalles, sin embargo no significa que no estén ahí.

"Pensé que quería algo [se extraña]", Trabajador4 ha reído con un poco de nerviosismo y aspira una bocanada fuerte de aire para inhalar. Pareciera que se siente estresado pero no es evidente, por el contrario se había quedado calmado esperando alguna respuesta del huésped, quien sólo cruzo frente a nosotros “... [exhala rápidamente] pero bueno, necesitamos saber si ponemos las amenidades completas, ya se montó con el aroma que quedamos pero nos faltan dispensadores".

A partir de una reflexión interna el huésped o el trabajador del hotel, podrían hacer consciencia de estos miniactos realizados en su día laboral, pero no así de 
manera cotidiana; Lo performativo, para estudios culturales y sociales, es entendido como la constitución de lo natural y lo normal (Markovska, 2008:4).

Por su parte, el performance es visto como lo más real. Trabajador4 adopta un papel: guarda silencio, oculta nerviosismo y sonríe; consciente de ser objeto de referencia para otros (el huésped, jefe u otras personas).

El performance puede definirse "como la actividad total de un participante dado en una ocasión dada que sirve para influir de algún modo sobre los otros participantes" (Goffman 1959:11). El grado de consciencia de Trabajador4 sobre su capacidad de influir, es justo lo que difiere si algo es natural o real; Trabajador4 había guardado silencio esperando una orden del huésped, actuaba sabiendo de antemano que su persona puede ser percibida -a partir de sus actos- por el huésped, y reflejaba corporalmente que había un interés por atenderle. Trabajador4 con su postura quiere que el huésped perciba atención, interés, confianza, orden y calma. Esto es más real, puesto que se hace con toda la intención de que sea percibido así. Los actos son realmente elegidos por Trabajador4 para generar una específica impresión.

La presencia de los dueños en el hotel, permite identificar más claramente este interés, por parte de los trabajadores, de cuidar sus actos. Esto no es exclusivo hacia los dueños, sucede con cualquier huésped, es una presión extra que se encuentra constantemente en el desarrollo de sus actividades. Todo debe salir 
perfecto para demostrar el estado de avance en el que está el desarrollo hotelero.

"Cada área ya sabe lo que tiene que hacer. Y pues en estos casos (visita del dueño), hay que estar pendientes, porque si algo falta, le entramos todos. Con tal de que todo quede bien. Te juro que hasta tenemos que entrarle a limpiar o tender camas, eso no es raro en la hotelería(...) hay que comportarnos de la mejor manera, se tiene que ver que dimos lo mejor y que fue sin esfuerzo de más, ¿sabes?” (Trabajadora5, comunicación personal, 22 de junio 2013).

Los roles son considerados performance, pues son adoptados por el trabajador para ser conscientemente juzgados, valuados y percibidos por una audiencia (Markovska, 2008:3). Por lo tanto, para efectos de este trabajo, performativo es un adjetivo utilizado para comprender una forma de ver los fenómenos: el espacio como la interacción de una serie de miniactos; y el performance es la manera en que los trabajadores se presentan, incorporan y viven el hotel, día a día.

\subsection{ACONTECER DIARIO}

Ama de Llaves ni siquiera piensa lo que va a decir: "Ocupa los de las Jades y ya que se vayan los regresamos. Avísame cuando ya estén disponibles para avisar a Concierge." Seguimos cuesta arriba entre las villas cuando a lo lejos reconoce a Camarista3 saliendo de Ropería con una bolsa de amenidades. "¡Recuerda que no puedes andar con esos aretes! Van a llegar los jefes y nos van a decir algo. Se te ven muy bonitos [se ríe], pero no es el uniforme". Al llamarle la atención, lo hace con voz dulce. Hay una sensación de camaradería. Ambas 
ríen, la camarista agacha la cabeza como sintiéndose avergonzada, no era la primera vez que se lo decían. Ama de Llaves, por su parte, sólo volteó a verla unos pasos más adelante para afianzar ese secreto entre las dos y reafirmó: "Es en serio, jeh!". Íbamos a paso acelerado, ella le daba vueltas a unas pulseras de tela que traía en la muñeca izquierda. "La imagen es muy importante, no creo que debamos ser tan exigentes, porque cada quien tiene una personalidad distinta y a una le gusta sentirse diferente a las demás. Pero aquí todos somos uno y hay que respetar el uniforme. Más ellas que son la cara al huésped." Su voz se escuchaba cada vez más incierta. En ese momento no era claro, pero a Ama de Llaves ya le habían llamado la atención por algo similar.

"Ya lo sabe, debe dar el ejemplo. La imagen es una de las cosas importantes que debemos cuidar en el hotel. Más cuando uno es jefe. ¿Qué caso le van a hacer si no procura su imagen y da el ejemplo? (...)Yo la entiendo, quiere verse bien, pero uno no debe resaltar tanto, debemos procurar una apariencia más natural. El chiste es que hay lineamientos, y eso no va. (...) Cualquier objeto puede interpretarse en su contra, por algún huésped. Que digan que se lo robaron, o algo así. Seguro significan algo para ella, tal vez del novio. No sé, pero si se las escondiera no habría problema. Pero siempre se la pasa jugando con ellas. Se notan. ¿Qué hago?” (RRHH, comunicación personal, 14 de julio 2013).

"Se las dio su mami" confiesa Camarista1. El hotel no es un área donde se haga pausa en la vida del ser humano para dar lugar al empleado. La empresa es otra área física donde se desenvuelve la vida del trabajador, y cuyos objetivos dotan de otras lógicas de interacción entre los empleados, mas no los despoja de su 
característica de ser multifactoriales. Los trabajadores no tan sólo tienen la capacidad de ser polivalentes, también dentro de la misma actividad, ellos se desenvuelven de distintas formas de acuerdo a las interacciones que tienen con los diferentes participantes de la misma organización: son polifacéticos.

“(...) ni se le notan, tiene una medallita para la protección. Todos tenemos algo así. Nos gusta. Cada vez que nos va a decir algo, se las arremanga. Digo, al final no es oro o plata, como luego traen las otras [camaristas]. Porque eso sí, algo aparatoso no es correcto, se malinterpreta, ¿no? (...) Yo traigo la foto de mi nena. $Y$ de vez en cuando cargo un anillo que me regalaron. Luego no me lo quitaba, pero pues también te estorban. Yo no digo nada, porque la verdad nos apoya mucho. Pero, pues [Ama de Llaves] sabe que no es en contra de ella, a veces se te olvida. (...) Creo que nos gusta vernos bien. A veces sólo es para presumir [se ríe]. Bueno, no todas" (Camarista1, comunicación personal, 20 de mayo 2013).

Camarista1 no cumple un solo rol dentro del hotel; Montaño y Rendón (2000) hablan de cómo en una organización, distinta naturaleza de intereses se conjugan para dotar de sentido a las relaciones y actos dados dentro de ella. Ya sean cadenas, aretes, pulseras o fotografías, no es raro encontrar un objeto personal que haga compañía a las camaristas en el día a día de sus actividades. Su significado puede ser variado, pero permite destacar algunos intereses prioritarios en su vida, durante las actividades laborales: status, identidad, familia, vanidad, compañerismo, entre otros. Dependiendo de con quién se encuentren interactuando, los intereses van acotando el performance diario. Nunca desaparecen, se encuentran ahí, latentes, e irán ocupando un lugar más 
central en la mente del trabajador, de acuerdo a las particularidades percibidas en el acontecer diario.

Frente al espejo de la sala de una villa vacía, Camarista3 se ha puesto la red por cuarta vez. "No viene a ver cómo te ves, sólo quiere ver cómo lo trabajas." La burla de Trabajador4 ha llegado a oídos sordos. Camarista3 se vuelve a desenredar el chongo. "¡No fuera el GH, ahí sí respetas y hasta te fajas!" Camarista3 voltea a ver a Camarista1 agradeciendo el apoyo moral.

"Todo depende de con quién te toca trabajar. Entras a Almacén y todos en la chocha. Hacen su chamba, pero ahí no importa si vas desfajado, tienen su uniforme, sólo que lo vienen a planchar en el asiento [se avergüenza de su tono]. El Conta rara vez lo vas a oír decir algo al respecto de la apariencia de su equipo de trabajo. Pero con nosotras, cualquiera puede llegarle con el chisme a RRHH. Es normal, nosotros trabajamos frente al huésped. Como quien dice, somos la cara" (Camarista1, comunicación personal, 20 de mayo 2013).

Trabajador4 está sentado en el brazo del sillón individual en la sala de la villa vacía. Camarista1 tiene un trapo en la mano derecha y mira atento a Camaristo1 que está "trepado" en la barra principal de la cocina integral, tratando de limpiar la campana. “¡Uy!, ¿quién te capacitó?” No hay ofensa recibida, sólo un grupo de trabajadores ventilando sus trapitos entre ellos. "Ay, bueno. Pues es que no alcanzo, y menos si siguen peleando, nadie me está haciendo caso y ya van dos pasadas que le doy." La verdad es que aún estando tan alta la campana, Camaristo1 le llega perfectamente, pero las carcajadas que ha repartido a diestra y siniestra no le permiten concentrar sus esfuerzos. "¡Apúrate! No tardan en llegar." Trabajador4 sigue admirando el peinado de Camarista3, quien va por 
el quinto chongo. Sus hombros demuestran fatiga y su cara un gran orgullo. Se escucha el cerrojo automático de la villa. “¿Está pesadito el sol, no?”, nadie responde. Ama de Llaves apenas entraba y en seguida desnudaba las verdaderas intenciones de la dilatación de los trabajadores en la villa. "Es en círculos Camaristo1, y hacia el mismo lado, sino se ve rayado. ¿Por qué no lo ayudan?" Con el separador en la boca y aún mirando al espejo, Camarista3 aclara entre dientes la escena. "Ya le dijo Trabajador4, pero no hace caso. Sólo falta él, ya terminamos todas las demás. Estamos esperando a que regrese de comer Camarista5 que es quien se queda en la tarde, pero sólo le van a quedar puros refresh, en caso de que llegara algún walk-in". Nadie ha cambiado la posición de sus cuerpos, Camarista1 sigue recargada en un pilar y Trabajador4 no ha hecho ni el intento de acomodarse el uniforme que deja ver un poco de su barriga. "Bueno, pues apenas empieza lo bueno. Yo creo que Camarista5 se va a quedar como responsable esta semana de las tardes, al menos hasta que se vayan [los dueños]. Sin duda ella sabrá qué hacer para que todo transcurra lo más tranquilo posible [el grupo asienta y ni siquiera osan a desmentir la aseveración]. Debemos estar atentos. Van a estar enfocados en el Spa, pero no le aflojen. Que se noten nuestras mejorías chavos..." Todos prestan atención fija a Ama de Llaves. Toman posición seria y se acercan al área de la cocina para escuchar las indicaciones de los próximos días. "Sobre todo debemos cuidar los detalles que mencionaron la vez pasada. Estén atentos a cualquier cosa e informen a Concierge si ven que salen los huéspedes. Ya ven que esos [recepcionistas] nunca saben nada. Al menos con ellos, confirmen doble vez 
cualquier detalle. No dejen los cojines de las terrazas al aire libre, por si llueve. Y si les dicen algo, digan que es una orden mía porque no tenemos repuestos". Todos ríen unísono. Es evidente el sarcasmo de Ama de Llaves, pero libera a los demás de una responsabilidad real.

"Mañana todos en RRHH firmando la renuncia por altaneros" replica Camaristo1. Él continúa limpiando a carcajadas, pero la campana sigue viéndose rayada. Está a punto de darse por vencido cuando lo detiene la mirada de Trabajador4. "Ni creas que te vas a bajar, tienes que aprender. Aquí estamos todos como apoyo moral, no es tan difícil. Presta atención." Sigue un aire de seriedad en la cocina de la villa. Trabajador4 se concibe un mentor para sus compañeros, las camaristas apoyan sus palabras asentando con la cabeza. Ama de Llaves sonríe. "No vayan a apagar el aire acondicionado y acomoden los cojines. No olvides darle una pasada a la mesa cuando te bajes. No quiero que vean tus huellotas ahí. Siempre queriendo destacar [se burla]". Camaristo1 ha dejado de reírse y finge indignación "Es para que sepan quién los está atendiendo [se detiene], a ver ¿cómo voy?". Todos admiran la campana, acreditan el trabajo como bueno. Se congratulan. Ama de Llaves se dirige a la salida: “¿A poco no somos una bonita familia?" El análisis del performance con base en el Spacing es sólo una forma de presentar esta diversidad de interacciones. Los personajes utilizados para hacer frente a los diversos públicos de una organización, presentan al trabajador como un ente polifacético, que construye una variedad de lógicas que se conjugan en una misma área física -empresa-.

"Y si estamos tristes, pues ni modo. Uno aprende a hacerlo, pon a uno de oficinas en Recepción a sonreírle a la gente cuando se ha peleado con la 
esposa. (...) la computadora no te dice nada si la ves con cara fea. No es tan fácil, los de hotelería lo sabemos, los demás no. No es tan sencillo trabajar así. Los problemas no se olvidan. Si llegamos a estar muy mal, buscamos hacer las [villas] vacías, para que no veamos al huésped cara a cara. Pero si Seguridad te habla, Mantenimiento te necesita para abrirles alguna villa, tampoco los puedes atender mal. Ellos a una sí, no saben tratar con servicio. (...) si están mal, están mal y hazle como quieras. Si una está mal, debe respirar, atender amablemente y esperar haber hecho un buen trabajo (...) y a ver que tal nos va con la propina. Sólo así confiamos que fue bueno nuestro trabajo" (Camarista1, comunicación personal, 20 de mayo 2013).

No es sólo portar el uniforme como se debe, sino simular una actitud. Y en el simular diario, con el paso del tiempo, se va creando una normalidad. Se establece un personaje. Los trabajadores han identificado que elementos de su persona y comportamiento son lo que deben procurarse con mayor atención frente al huésped. Así mismo, relacionan ciertas prioridades diferentes en lo que su cuerpo proyecta al escuchar a Ama de Llaves en asuntos del trabajo, que cuando trata asuntos personales o mientras se encontraban solos en la villa.

"Cuando un individuo o actuante representa el mismo papel para la misma audiencia en diferentes ocasiones, es probable que se desarrolle una relación social. Al definir el rol social como la promulgación de los derechos y deberes atribuidos a un status dado, podemos añadir que un rol social implicará uno o más papeles" (Goffman, 1959:11).

Por ello, ser una camarista no es un rol absoluto, es un cúmulo de personajes papeles- que se reúnen en una misma trabajadora. La camarista, frente a un 
huésped, debe ofrecer un ambiente de serenidad, complacencia al cliente y rectitud; frente al Ama de Llaves, la camarista debe sobresalir por su eficiencia, dinamismo, compañerismo y orientación al ahorro de insumos; frente a los otros departamentos debe dar prioridad al trabajo en equipo, la resolución de contingencias y velar (disimular) los problemas -o faltantes- en la medida de lo posible; y frente a sus compañeros debe legitimar un know how, resistencia a las condiciones de trabajo, y lealtad al departamento que pertenece.

\subsection{COMUNICACIÓN: HABLA Y ACCIONES}

" $<<$ Nothing never happens $>>$ [nada nunca pasa]. Siempre sucede algo en la escena de la presentación de uno mismo (Goffman, en Winkin,1984:105)".

Trabajador1 toma la radio, aprieta el botón en un movimiento automático y levanta la ceja: “¿Concierge me copeea?”-“¡Le copeeo!”

Son casi la una de la tarde en V\&S y el sol está en su punto más alto. La humedad ha bajado un poco y el estómago hace su segunda llamada. En un tono burlón y sucinto Trabajador1 anuncia la conclusión de su primera parte de actividades del día y su intención urgente por bajar al comedor. Para Hall (1972:9), "el lenguaje prolonga la experiencia del tiempo y el espacio". Por lo tanto, la interpretación del espacio es resultado de los actos comunicados, que se permiten las personas dentro de éste. El espacio entonces, participa en la formación de las relaciones estrechadas al interior de la organización; nuevamente estaríamos hablando de su participación en la dinámica organizacional. 
En la recepción Trabajador8 no ha dejado de contestar llamadas telefónicas. El ritmo de sus respuestas y la atención a las dudas y solicitudes que se deslizan por el auricular, lo mantienen aprehendido a un espacio regido por la eficiencia y la eficacia. Es cortés y pausado. De vez en vez toma nota en un pedazo de papel reciclado y busca información en la computadora. Hay una música instrumental de fondo a la que él parece no prestar mucha atención. “¿Concierge me copeea?" Cuelga el teléfono -un huésped a pedido toallas en la alberca- y en un tono hilarante y agradecido por el receso que implica atender este llamado, contesta "iLe copeeo!"

Como virus, el tono hilarante se replica en las mentes de todos los operadores con radio en V\&S. Hay risas de confidencia entre los radioescuchas. Se disfruta la broma y se regresa a las actividades. La percepción de conjuntos significativos en los actos de los trabajadores, ofrecen a detalle un análisis de la situación real del hotel; muy acorde a la concepción de la comunicación, bajo la teoría freudiana: nada es casual -determinismo psíquico ${ }^{18}$ - (Bateson, 1971 en Winkin, 1984:125).

Si es a través de las organizaciones que los seres humanos alcanzan un fin en común (Scott, 1981); De igual forma, toda relación inserta en el hotel, mantiene un interés. El interés varía de acuerdo al ámbito en el que se desenvuelven y se expresa en el proceso de la comunicación.

"¡Ya voy!" -"Enterado". Se cierra la conversación. Trabajador8 enlista las últimas

18 “...la teoría freudiana quiere que todo lo que sucede tenga una significación, tanto en el sentido en que todo acontecimiento forma parte del intercambio como en el de que nada es fortuito. Freud ponía el acento en el determinismo psíquico, en el hecho de que ninguna palabra pronunciada y ningún detalle de un sueño que uno ha tenido puede ser accidental. Un hombre no puede haber <<soñado solamente>>. (Bateson, 1971 en Winkin, 1984:125)" 
indicaciones a su compañera de departamento y le pide al Bell-boy un aventón. Esto último lo ha hecho en un tono mandón, pero bromista. Subiendo por la colina en el carrito de golf, ya no hay presión en sus ojos, pero sí en su cabeza. Sólo tiene 20 minutos para comer. Sin hacer gran consciencia, enlista los próximos temas a conversar con Trabajador1 y prioriza. Con Bell-boy sólo han acordado que comerá después de él y en compañía de la recepcionista. Bell-boy sólo acata. No está el Chief Concierge y se sabe en desventaja frente a Trabajador8. No hace muecas, no dice más allá de lo necesario. Cuando Trabajador8 se baja y le pide regrese por él. Bell-boy finge no escuchar y acelera. Apunto está de murmurar cuando se cruza un huésped, que camina sin rumbo: "Buenas Tardes, ¿le puedo ayudar en algo? ¿Gusta que lo lleve a alguna parte, señor?" -"No, gracias. Sólo camino". Bell-boy inclina la cabeza y cierra los ojos al ritmo, como si comprendiera entre líneas que no quiere ser molestado. "¡Suba!, lo llevo arriba. Es más agradable la vista y se puede caminar mejor." Bell-boy a dado una orden confiada, su rostro y cuello, no tiemblan, son firmes. Sólo ha sido una orden, pero sus ojos le han dicho más al huésped que cualquier otra palabra que pudiera pronunciar. El huésped sube y con la pena de haber sido descubierto en un mal momento, acepta. Se deja consentir. Bell-boy lleva al huésped colina arriba. No dice nada en todo el trayecto. El huésped va sumergido en su letanía mental, ni siquiera siente la presencia de su conductor. Baja la velocidad y frena. Bell-boy se vuelve a verlo, como buscando alguna otra forma de atenderle. "¡Gracias!" -“Un placer." El huésped lo mira, se baja y admira la playa a lo lejos. Bell-boy parece saber que no hay más que hacer. 
Regresa por el camino andado hasta la caseta principal. Estaciona el vehículo, vuelve a cruzar la caseta de vigilancia y entra a la recepción. -“¿Cómo ves a tu jefe?" -"No es mi jefe [se ríe]. Ahora ¿qué te dijo?” Trabajadora9, la única concierge, es nueva en V\&S, no tiene mucha capacidad de decisión por el momento, pero ya ha identificado uno que otro aliado para abrirse camino en la empresa. Bell-boy, conocedor de todo el hotel y con gran interés de obtener el puesto del otro concierge -Trabajador8-, es su mejor apuesta. En una organización se presentan distintos tipos de relaciones entre los trabajadores que la componen, y en estas relaciones se intercambian ideas. Estas ideas son compartidas a través del lenguaje: parte de la comunicación. La importancia del habla en el proceso, o al menos una parte de ésta, se encuentra en la capacidad que tiene como proceso de influencia. Por lo tanto, la relevancia recae en los objetivos que busca cumplir.

Cruzando la cocina, por debajo del restaurante, se encuentra el comedor de empleados. Una puerta lo separa de las áreas públicas del hotel, y se identifica por un letrero adherido: "FAVOR DE NO AZOTAR LA PUERTA". En su interior cuatro mesas de plástico con sus respectivas sillas, un microondas y una barra donde se colocan los alimentos, sin clima u otro tipo de ventilación; ofrece a los trabajadores un área llena de intimidad y compañerismo para tratar un sin número de temas. Ahí Trabajador1 ha tomado la rienda de la conversación, cuando Trabajador8 regresaba de una llamada que había recibido en la Cocina. Primero se agradeció en voz alta que el menú de la comida fuera respetado, en un tono de mofa. Hablaron sobre lo bueno del caldo y sus bondades como 
remedio para la cruda. Después trataron un rumor sobre la asistente de AyB y dedicaron el resto del segundo tiempo y el postre a la planeación de la tarde: ¿Dónde irían?, ¿quiénes irían? y ¿hasta qué hora se irían? "Yo no ando con mucho jale, pero ¡vamos!” Trabajador8 se levanta por más agua, toma el vaso de los dos, los demás compañeros que habían llegado un poco antes se van despidiendo: "Provecho". Como ya se mencionó, el spacing organization implica ver al trabajador bajo una gama de personajes. La multiplicidad resulta en una diversidad de roles dentro de una misma organización, por parte de un mismo integrante de la organización; Esta distinción de actuar, implica a su vez una intención diferente en la comunicación.

Si de acuerdo a lo que percibimos, hay comunicación. Entonces cada personaje, significaría una particular naturaleza en el proceso. Pero, ¿qué implica la comunicación? Este proceso "no se trata de establecer una oposición entre la comunicación verbal y la <<comunicación no verbal >>: la comunicación es un todo integrado (Winkin,1984:23)"; Implica la percepción de lo que hacemos, lo que somos, lo que pensamos, lo que hablamos, lo que gesticulamos; y en esta multidireccionalidad de la comunicación, en la comunicación nos construimos por lo que percibimos de los demás.

Trabajador8 aprovecha lo vacío del comedor, sirve el agua con un poco de prisa y toma asiento. "Y que lo regresan..." -“¿Cómo, y eso?” Trabajador1 arrima su asiento y agradece el vaso con agua. No hay intriga de por medio, mas bien preocupación. Una preocupación tal como la de un amigo, que prefiere 
autodenominarse su hermano, para hacer hincapié en la lealtad correspondida. "Pues así, ¡no más!, creo que no le van a soltar el puesto. Y si no lo ascienden, entonces yo me la pelo. No sé. ¿Qué hago?, ¿me aguanto? Todo puede pasar, ¿tú no has escuchado nada? Mira, en oficinas no lo quieren, y abajo sólo habla, pero nosotros hacemos toda la chamba. Se la pasa hablando de todo lo que falta, y de cómo podría mejorarlo. Pero, no sé... le falta algo. Pa'mí que no se lo dan. La están pensando mucho. Y si traen alguien de'fuera, seguro me voy a quedar ahí. Yo voy a seguir apechugando, a ver qué pasa". Trabajador8 tiene una mano sobre su cara, la pierna le tiembla y Trabajador1 le sirve otro vaso con agua. Entran otros compañeros, es hora de regresar: "Provecho". La comunicación se presenta como elemento del desarrollo no tan sólo organizacional, sino de los integrantes de la empresa, pues es participe y referente de la construcción de la acción social. "Incluso si un individuo puede dejar de hablar, no puede dejar de comunicarse mediante el lenguaje del cuerpo. Puede hablar a propósito o no, pero no puede realmente no decir nada (Goffman, citado en Winkin,1984:105)". Bell-boy tan sólo escuchaba a Trabajador8 mientras lo llevaba al comedor. Sin embargo la confianza entre ellos no permitía un nivel mayor de conversación. Era evidente la ausencia de estima y no había necesidad de responder para hacer saber al otro, que no era parte de sus responsabilidad hacerla de taxi, si lo hacía era por cierta figura de autoridad que se le depositaba en ausencia del Chief Concierge. Las acciones y algún gesto, tomaban un papel más importante en la comunicación, que las palabras. No es que los trabajadores se comuniquen, mas bien los trabajadores son 
piezas en la comunicación. La comunicación también es un concepto performativo. Bajo la idea que no se puede silenciar al cuerpo. Se rescata que la comunicación es constante, continua. Pero no significa que surja de los trabajadores. Trabajador1 no reacciona a partir de lo que comunica Trabajador8, mas bien ambos intercambian sensaciones, participan dentro de un proceso de comunicación ${ }^{19}$ (Winkin,1984).

Así como "todos los hombres son cautivos del idioma que hablan" (Hall (1972:7), de manera más amplia, podemos entender que nuestro lenguaje "es algo más que un simple medio de expresar el pensamiento"; el performance está influenciado por el lenguaje.

Cuando Trabajador8 y Trabajador1 deciden hablar, la elección del tema y su intención también participan en la comunicación. Austin (1962), afirma que en el habla, más allá de las palabras existe una intención. Se declara una postura, y así se produce un acto. El acto de habla ${ }^{20}$ (speech act) es un elemento esencial que cobra fuerza dentro de un espacio: decir algo es hacer algo; al decir algo hacemos algo; y porque decimos algo hacemos algo.

En este caso, parece que se le dota de un espacio-tiempo al acto de habla. No tan sólo se trata de enunciar palabras, sino del mismo acto como hecho de

\footnotetext{
19 “(...) hay que ver la comunicación como un sistema (un proceso) en el que los interlocutores participan. Decir que el individuo A comunica una multitud de mensajes verbales y no verbales al individuo B es utilizar (...) el modelo telegráfico en el que la comunicación se considera como una sucesión de acciones y reacciones:

"Un individuo no se comunica, sino que toma parte en una comunicación en la que se convierte en un elemento. Puede moverse, producir ruido...., pero no se comunica. En otros términos, no es el autor de la comunicación, sino que participa en ella. La comunicación en tanto que sistema no debe pues concebirse según el modelo elemental de la acción y la reacción, por muy complejo que sea su enunciado. En tanto que sistema, hay que comprenderla al nivel de un intercambio. (Birdwhistell, 1959:104 citado en Winkin,1984:77)".

${ }^{20}$ Austin (1962) clasifica los actos en locutivo, ilocutivo y perlocutivo. El primero refiere a la expresión de algo, el segundo a lo que se pretende hacer al decir algo (lo dota de intencionalidad o "fuerza ilocucionaria") y el tercero a lo que efectivamente se consigue al llevar a cabo el acto de habla (que bien puede o no coincidir con lo que el hablante previó "ajuste entre la ilocución y la perlocución").
} 
asumir una posición o situación dada. Tal cual lo dice el término, es un acto, es performativo.

"Siempre surge algo. (...) y no te puedes quejar, las cosas se hacen bien y de buena forma. (...) Hagas lo que hagas: ¿Y tu respaldo?" (Trabajador1, comunicación personal, 03 de junio 2013).

En la hotelería, el vocabulario utilizado denota en gran medida esta cualidad performativa del habla. Hay términos, modismos o adjetivos calificativos que parecen ser un enunciado, pero en su connotación se está haciendo algo en vez de diciéndolo.

Trabajador8 ha regresado a la recepción para hacer relevo a Trabajadora9. Antes de salir acompañada por Bell-boy, como minuta, menciona cada una de las acciones que considera relevantes para que Trabajador8 esté bien informado, por si necesita aclarar dudas a los huéspedes o si pregunta algún jefe. "Te estaba buscando el Chief por la radio(...) y vinieron de Ventas a depositar un sobre en la caja fuerte, si firmaron la bitácora, y llamé a uno de Seguridad para que tomara nota. ¡Ah!, también vino Contabilidad y me dejo la papelería requisitada”. -“¿Y tu respaldo?” preguntó Trabajador8 evaluando la situación. "No, pues nada más la dejaron y yo les firmé de recibido". -"Pero nosotros ¿cómo sabemos qué firmaste?, si nos llega a faltar algún folio, ¿cómo avalamos que no lo hemos recibido?" Trabajadora9 tuerce la boca sin querer, sabe que olvidó algo importante: solicitar una copia. Hacer "las cosas bien y de buena forma" refiere a los procedimientos básicos del hotel. Habla de un compromiso al seguimiento de toda toma de decisión a partir del uso de un elemento en particular: el respaldo. En principio hacer las cosas "de buena 
forma" implica la actitud de servicio frente al huésped, también podría interpretarse una buena actitud frente a los compañeros de trabajo, es decir responder a las solicitudes de otros (eficiencia), sin quejas ni a regañadientes. Pero hacer las cosas bien, no tan sólo se refiere a la actividad en sí (eficacia), refiere en gran medida a los procedimientos y más específicamente al respaldo con el que avalas la respuesta dada a la situación. El respaldo es el documento que acompaña al reporte de actividades. En este se presentan datos claves de la acción concreta realizada y su importancia gira entorno a las firmas que contiene. Las firmas determinan quién autorizó la acción, quién testificó lo que se hizo, o en caso de recursos, quién los recibió (en el caso de requisiciones de compra, el respaldo es la presentación física de tres cotizaciones distintas, que avalan un análisis de la mejor opción de compra). Este respaldo es una actividad común en la actividad contable (por ejemplos las facturas firmadas de recibido) y fue retomada en la operatividad hotelera, como una forma de deslindar responsabilidades, por ello cada firma en el respaldo implica la existencia de una copia. El respaldo es vital en el trabajo diario, a tal grado que es común escuchar que se le dice a los nuevos: "De todo lo que firmes, que te den una copia", "Si no hay respaldo, no se hizo" y la más común dicha con tono de burla: “¿Y tu respaldo?"

Lo performativo en esta serie de palabras, se sitúa cuando similar a un slogan, la frase es adoptada por los trabajadores del hotel y la utilizan para "bautizar" a un nuevo integrante del equipo.Trabajadora9 sabe de la importancia del respaldo, y si no lo sabe, se le hará de su conocimiento a la mala. Hasta que ella comprenda 
la importancia de respaldar hasta la más mínima decisión. En el momento en que la pregunta le sea lanzada y la responda mostrando en mano el respaldo, finalizará la iniciación. Trabajadora9 por fin será "de hotelería".

Como ésta, las "emisiones performativas ${ }^{21 "}$ (Austin, 1991) no son ni verdaderas, ni falsas, pero no significa que carezcan de sentido. El espacio es quien dota de sentido a las emisiones; requiere de circunstancias apropiadas para darle sentido a la frase, donde en ausencia de este contexto la frase no "realizaría" dicho acto. Para el hotel las actividades pueden ser visiblemente comprobables de haber sido hechas, pero si no existe el respaldo físico (en papel) de que fue hecho (testigo) y autorizado, la actividad automáticamente es considerada como no realizada. Es una forma de enseñarse a ser ordenados y llevar un control dentro de su actividad diaria, la cual suele convertirse en dispersa e ineficiente al querer atender todo al mismo tiempo. La importancia de la acción también puede denotarse en el número de firmas requeridas en el respaldo.

No es de sorprenderse que en varias ocasiones el respaldo se haya convertido en un documento que retrase la realización de la actividad -por la(s) firma(s) de autorización-. Y como la eficacia es un eje fundamental de la lógica hotelera, el respaldo por si solo, también "respalda" que las partes han sido informadas de la necesidad de atención de alguna acción, pero que no se ha finiquitado por falta de autorización. Por eso se entregan las copias del respaldo a las partes

\footnotetext{
${ }^{21}$ Uno de los ejemplos más comunes es el caso de la ceremonia religiosa de matrimonio, donde al decir "Sí, quiero" no se enuncia algo, sino que en ese determinado contexto se realiza "el acto de casarse".
} 
interesadas (al estilo de contrafactura en la contabilidad), o se llevan los registros en bitácoras, las cuales también van firmadas.

Trabajadora9 no quita el dedo del renglón. En el comedor aprovecha la relación del Bell-boy e inicia conversación con quien se deje. Como compañera nueva, genera curiosidad entre los trabajadores, pero obtener su apoyo o aprobación no será tan sencillo.

Como se mencionó, la naturaleza de las relaciones que van formando entre los miembros de V\&S, determina en parte la información que comparten. La obtención y manejo de la información es parte de estos recursos que se utilizan para obtener una posición ventajosa dentro de la organización del hotel.

Es claro que existe una "élite", constituida por aquellos trabajadores que tienen mayor conocimiento de la operación real del hotel. Ellos se mantienen a través de mecanismos básicos como lo es la imposición de estándares para la distancia: distinción de ellos (los que conocen), frente a aquéllos (que son más ignorantes).

Si bien Trabajadora9 como Concierge, tiene un puesto más alto que un bell-boy, Bell-boy tiene algo que Trabajadora9 no tiene: conocimiento en forma. Ella no necesita obtener suficiente información, sino saber cómo utilizarla para ser tomada en cuenta en los procesos de toma de decisión y que poco a poco se le vayan delegando responsabilidades. Esa es la única forma de asegurarse un puesto en el hotel, colocarse como pieza clave en la operación de V\&S, y sólo podrá lograrlo a través de la credibilidad. Camarista5 está en el postre, le ha dado varias vueltas a su fruta y aún no le da bocado alguno. "¿Cansada?" 
Camarista5 voltea a ver a Trabajadora9 "Me toca la guardia". En momentos de alta ocupación, los turnos se ajustan un poco, para poder tener gente adecuada atendiendo las necesidades de los huéspedes. Camarista5 no tiene mucho tiempo en el hotel, pero poco a poco fue demostrando su conocimiento en la resolución de problemas y el procedimiento en la atención de crisis de los huéspedes. El grado de experiencia la posiciona en un sitio de mayor responsabilidad frente a sus compañeras. La ventaja no es el sueldo, sino su cercanía con la Ama de Llaves y capacidad para delegar actividades a las demás. No tiene una carrera universitaria o técnica como Trabajadora9, pero sus más de 21 años en el ramo le permiten andarse con mayor soltura. Bell-boy y Camarista5 se han hecho grandes amigos, gustan de trabajar en el mismo turno y buscan cualquier oportunidad para hablar de los diversos problemas de sus actividades, como si fueran los encargados de los departamentos. "Ya le dieron su primer llamada de atención, olvidó el respaldo", informa Bell-boy a Camarista5 en un tono paternal. "¿De verdad?, a todos nos pasa. Ni te preocupes al Chief a cada rato se le olvida revisar el rack de habitaciones. Ni siquiera pide copia". Trabajadora9 sabe de qué hablan, pero a la vez no. Si pregunta, la harán a un lado, la tacharan de aprendiz, o tal vez ignorante. No será uno más de ellos. Su mejor oportunidad es reír y fingir asombro: “¿En serio?, para la próxima que se entreguen los 'Hoy Amanecimos' le voy a decir. ¿Y tu respaldo?".

En la plática, un silencio interrumpe. Error. Hasta para quejarse hay formas. Trabajadora9 ha dejado en evidencia no sólo a su jefe directo, sino a su 
departamento. Todos saben que el reporte mencionado (que contiene los datos diarios del status del hotel) constantemente tiene errores. Pero ella ¿qué podía decir?, aún no había demostrado tener un conocimiento del actuar en el hotel, y menos aún de cómo manejarse entre los compañeros. Nadie dijo nada.

A partir de lo observado en la praxis y los documentos proporcionados por RRHH sobre sus cursos de capacitación, sensibilización, inducción y otros; la distinción del conocimiento, como cuestión de forma y no de acceso, se identifica en los siguientes casos: 1) el uso de cierto vocabulario: briefing, walk-in, amenities, check-in, check-out, concierge, servicio, la guardia, atención, servicio al huésped, calidez, respaldo, check-list, asignación de tarifa, bloqueo, cambio de habitación, control de llaves maestras, consignación, forma de pago, orden de servicio, pronóstico de habitaciones, ocupación, rack de habitaciones, registro, reserva, reserva garantizada, depósito de agencia, grupos, room status, tarifa rack, tarifa de convenios, late check-out, voucher, entre otros; 2) el manejo de los formatos y procedimientos requeridos: como el respaldo, órdenes de servicio, y saber qué área resuelve determinados asuntos y cómo solicitarlo; 3) el respaldo de una jerarquía dada: ya sea por designación o por el liderazgo a partir del carisma, o la administración de ciertos recursos; y 4) en el conocimiento y técnica del manejo de insumos. Todo ello dota de herramientas para la diferenciación entre trabajadores generales y trabajadores de hotelería, y hasta cierto punto, determina roles, a partir de la credibilidad. Un empleado de áreas públicas con mayor conocimiento -en forma- tiene mayor validez de 
argumentar frente a otro trabajador que no lo tiene, aún teniendo un nivel de acceso a la información mayor o similar.

Por lo tanto, el know how de la forma acota los procesos de comunicación. No tan sólo quien tiene el conocimiento en forma sabe que tiene mayor validez su opinión, sino que aquél que no lo tiene, hasta cierto punto respalda esta autoridad, pues la forma lo pone en un nivel menor de credibilidad, aunque su opinión sea contraria; validez que incide en los flujos de comunicación: limita y libera.

Es común oír quejas en el comedor. Trabajadora9 no había sido impertinente en ese hecho. Pero el comedor es un espacio pequeño que es ocupado por todos los departamentos del hotel, hasta oficinas administrativas. Las quejas son depositadas en los oídos de los demás a partir de la exaltación del cúmulo de trabajo, el gusto que les da realizarlo y lo que necesitan para hacerlo mejor. De otra forma se hacen en corto, en los pasillos, en la caminata de un lugar a otro, en la comodidad de los lugares físicos de cada departamento. O bien, de manera formal en la oficina de RRHH o en las juntas de área.

"Uno de los problemas básicos de muchas actuaciones es, entonces, el control de la información; el auditorio no debe obtener información destructiva acerca de la situación que los actuantes tratan de definir ante él. En otras palabras, el equipo debe ser capaz de guardar sus secretos y de mantenerlos guardados" (Goffman,1959:76). 
Ningún departamento debe saber lo mal que está el otro. En cualquier momento puede ser usado en su contra. Por ello, la queja en el comedor o en reuniones informales sólo se hace a partir de una figura de mártir. Sólo así puedes ir construyendo marcas de guerra, sino es sólo una queja de aquéllos que no son de hotelería, y por ende, no saben, no aguantan nada.

De esta forma, lo que se comunica y dónde, sigue una lógica básica: velar la información. Por ello, es importante identificar lealtades y hacer filtros de tus opiniones y sensaciones.

"Al huésped no se le dice nada de la operación, sólo del servicio. A los dueños no se les habla de asuntos que pongan en duda el trabajo del Gerente (...) (Trabajador8, comunicación personal, 16 de junio 2013)".

Primero se le es leal al hotel, luego a tus jefes, de ahí a tu departamento y finalmente a tus cuates. Camarista5 y Bell-boy lo saben, por ello cuando se confían anécdotas de sus departamentos, muchas veces son alteradas. No tienen por qué saberlo todo. Ellos lo saben. Es un acuerdo tácito entre compañeros.

"Cada departamento tiene sus trapitos. No te creas. Cuando salen algunos te enteras de cada cosa. Pero siempre queda algo por decir. Somos leales. Para saberme los chismes, tengo que estar ahí conviviendo con ellos en el departamento, ser uno más del grupo. Y ni así. Pero pues es algo normal, ¿no? En todas las empresas hay secretos. Es más, hasta entre hoteles. Todos nos conocemos y hemos trabajado en varios. Pero hay muchas cosas que yo no comento sobre los procedimientos de los demás hoteles. No es correcto. Nunca se sabe, por conocidos de conocidos, a quién le estás soltando la información" 
(RRHH, comunicación personal, 14 de julio 2013).

Trabajador1 se encuentra en Ropería esperando el cambio de turno. "La verdad es que no se lo van a dar. Tiene razón, para mí que van a contratar a alguien más. Pero pues es que el otro parece que es nuevo." Su expresión es de reclamo, sus manos se tensan y parece darle mil vueltas en la cabeza a una sola idea; se siente limitado. "No es sólo el Chief, también a mi cuate se le va la onda, pero no lo admite. En estos casos lo mejor es no meterse. Yo finjo que le creo todo, y el otro finge que me cree todo a mí." Por el bien de la amistad, por el bien de la operación. Porque así es la lógica básica de la hotelería: ¡Hazte bolas, pero no digas nada! Que parezca que fue sin esfuerzo alguno (o dentro del rango de las propias capacidades). La comunicación en los espacios se veda por la exclusividad de su dinámica y percepción de los actores.

\subsection{JERARQUIZACIÓN DE ESPACIOS}

Apaga el cigarrillo en la suela de su bota y en un movimiento rápido y automático de dedos, similar a un chasquido, conduce la colilla del cigarrillo tan solo unos pasos lejos de su perímetro. No lleva uniforme, y vaga entre los escombros y las plantas sin rumbo alguno ni interés por dejar de hacerlo por otro ratito más. Se detiene. Se siente observado, voltea a ambos lados y en la certidumbre de su soledad, se dispone a revisar algo en su bolsillo: su celular.

La mitad de la cara de Trabajador7 está tapada por una gorra café y cuadrada. Las rutas usuales de los huéspedes, por la distribución del desarrollo hotelero, no frecuentan esas áreas, lo que permite a Trabajador7 sentirse con la confianza de hurgarse la nariz. Se escuchan murmullos, que al acercarse desdibujan una 
conversación entre un administrador de la Constructora y un peón. Trabajador7 se apresura a tomar una playera que lleva unas palabras en la espalda y la extiende como si fuera a ponérsela. Los dos interlocutores, pasan frente a Trabajador7 y éste se limita a asentar con la cabeza y mitigarse la comezón de la nariz, con un sutil fruncimiento. "Así son la mayoría, son albañiles, personal acostumbrado a otro tipo de funcionamiento. Normalmente tendríamos un equipo capacitado de Mantenimiento, pero aún no está todo el hotel, así que ocupamos a los de la Constructora como apoyo, hasta que nos entreguen todas las áreas." $\mathrm{RRHH}$ ha insistido en que tomemos un carrito de golf y hagamos un rondín por todo el hotel. V\&S tiene un gran terreno en construcción y otro más grande sin aprovechar aún. "Es la siguiente etapa, la tercera. Bueno, eso si no se nos ocurre nada más, antes." La risa de RRHH no es sutil, hay un sentimiento de vanagloria entre sus palabras. No es que presuma sobre ella, pero poco a poco los trabajadores del hotel han legitimado su posición frente a los demás en V\&S.

"A diferencia de otras propiedades yo tengo a mi cargo la parte operativa. Es decir, la parte de concierge, ama de llaves, limpieza de áreas públicas, básicamente. $Y$ luego, tengo otra gente que me da servicio a mí, que no dependen de mí, pero me dan servicio. ¿Quiénes son? Son parte de la misma compañía, pero son independientes: Tengo la jardinería, me hace los jardines, planta, siembra, riegan, pero no están dentro de mi empresa, es una empresa externa; todo el mantenimiento que se da, si algo se dañó, si hay que pintar, hay que reparar o una fuga, lo hace una empresa que es del mismo consorcio pero es una empresa externa, yo dependo de ellos para la limpieza de alberca; y la parte de alimentos y bebidas, hay un restaurante que le da servicio a toda la 
propiedad, pero también es una empresa externa que me hace todo ese servicio." (Gerente, comunicación personal, 27 de abril 2013).

VS se presenta como una operadora que hace uso de la tercerización para atender las distintas áreas de su operación diaria. Todas estas áreas entonces cuentan con una estructura diferente, sin embargo, al insertarse dentro de las actividades internas, responden no tan sólo a su jefatura directa, sino a la Operadora del Hotel, y al dueño del desarrollo (Véase Gráfico 1).

\section{GRÁFICO 1. REPRESENTACIÓN DE LA ESTRUCTURA DE V\&S}

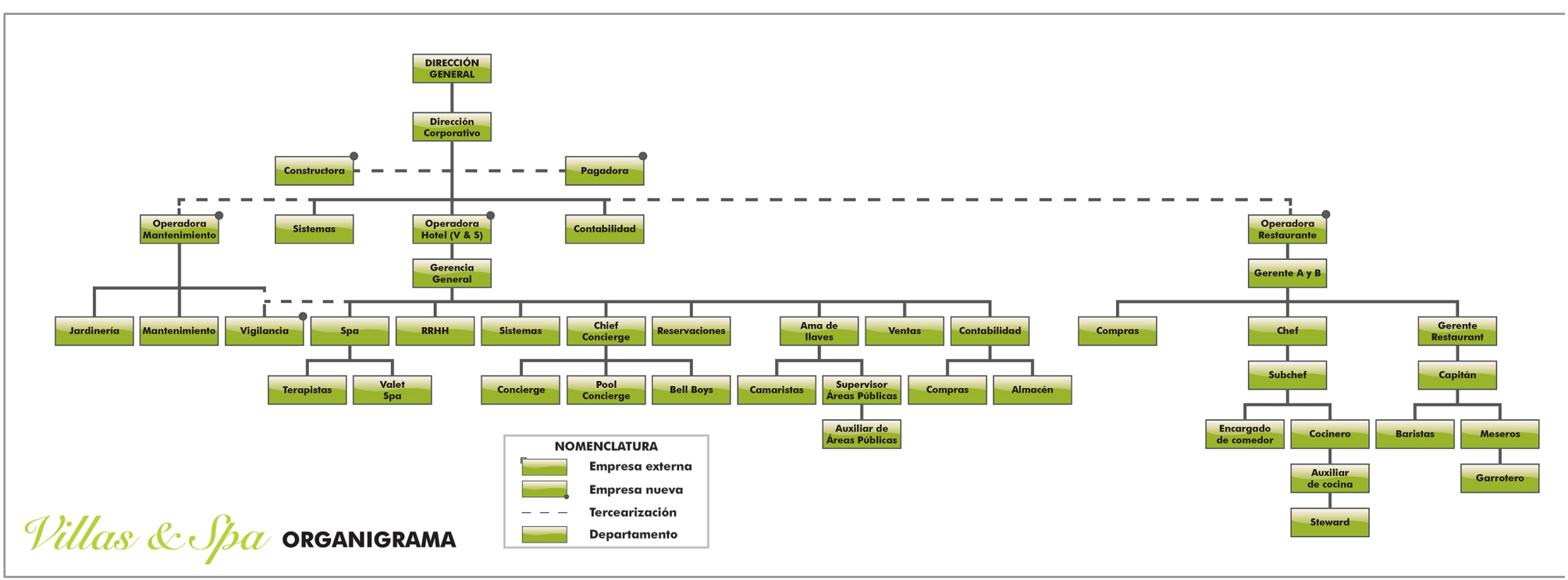

Fuente: Elaboración Propia.

Su integración ha sido un trabajo constante de $\mathrm{RRHH}$, quien consciente de las diferentes costumbres de desempeño entre los trabajadores, ha promovido cursos de sensibilización, también llamados Actitud de Servicio.

En el apartado anterior se identifica una diferenciación del espacio en V\&S, a partir del personaje adoptado por el trabajador. Un personaje con intereses en particulares, concibe una función prioritaria. Similar a la concepción de Hall 
(1972), la clasificación de los espacios depende de la naturaleza de su función; es decir, los espacios en una organización son diferenciados en nuestra mente por la observación de las actividades que se desarrollan dentro de ellos. El espacio no sólo forja en gran medida el comportamiento (Hall, 1972:132), sino que se nutren uno del otro en un proceso continuo. La función del Servicio hacia el huésped, se permea a un gran ritmo entre las distintas firmas, gracias a los esfuerzos de RRHH, pero principalmente a la fuente de utilidades, que representa la parte hotelera de V\&S.

Sin duda alguna, esta liquidez a promovido que los directivos respalden con mayor fortaleza las sugerencias del Hotel y sus colaboradores ganan terreno frente a los demás. Quien deseé seguir siendo parte de este proyecto debe entonces adoptar el personaje clave: trabajador orientado al huésped, o en otras palabras, trabajador de hotelería.

“¿Hoteleros? ¡No!, ¿cómo crees? Esos son los dueños, los que ponen la lana pero no tienen la sensibilidad para operarlos. Nosotros somos de hotelería. Es distinto." Trabajadora4 se concibe distinta, como de una raza diferente, no mejor. O al menos no lo dice explícitamente. El tono de sus palabras sin duda remarcan un orgullo por su trabajo. Trabajadora4 aún no tiene una carrera, espera tenerla algún día. Por el momento se dedica al cien al hotel, le da el dinero suficiente para atender a su beba de 5 años. Siempre ha trabajado en limpieza, pero su mediana trayectoria en hotelería, la han hecho una experta en desaparecer frente al huésped y delegar adecuadamente dudas de los huéspedes cuando ellos la perciben y cuestionan. "Es muy sencillo, cuando te gusta. Se trata de ser 
tú, cordial y respetuoso. Se trata de hacer sentir bien a la gente." Su habilidad en los pisos, la hacen la consentida de los administrativos. Platica, pero no mucho. Y si escucha, no comenta. Por lo contrario, cuando ve que los humos se tensan, corre a preparar un cafecito y se lo ofrece a la víctima de estrés. Sabe la ocupación del día, tiene una agenda en su cabeza de las actividades de la mayoría de su área y es tan eficiente, que pudiera hacer su trabajo y el del Concierge sin obstáculo alguno. "Pero, y ¿quién los va a atender?" Tales cualidades las ha aprovechado para hacerse de un horario óptimo para atender a su hija y sumergirse de lleno en su trabajo en el hotel. "Algunos departamentos tienen ciertas bondades que otros no. Aquí te la pasas limpiando, pero obtienes un respeto por lo que haces. Limpiar no es algo denigrante, es parte de atender al huésped. Ofrecer un área limpia. Sin esta limpieza no habría huéspedes. Mis compañeros lo saben, y respetan. Soy una más del equipo y aprendo sobre otros asuntos que en otros trabajos no te permitirían. Me enseñó a enseñarle a la gente, a hacer programas de las actividades, a hacer pruebas de productos $y$ a pensar en los gastos(...), es a mí a quien preguntan sobre algún proveedor. Yo los conozco, los he usado y sé cual rinde."

La ausencia de un Organigrama fomenta esta capacidad de ciertos departamentos de ganar terreno de influencia sobre otros. En el ramo hotelero, los departamentos se jerarquizan constantemente a partir de su cercanía con la atención al cliente. Es decir, el origen de una solicitud del huésped, modifica el nivel de autoridad que tenga un departamento sobre otro. Finalmente, todos se encuentran por debajo del Gerente, entonces si el huésped necesita una toalla, 
Trabajador8 en el departamento de Concierge (quien recibió la llamada directamente de la villa del huésped) es el encargado de supervisar que la acción haya sido realizada. Se responsabiliza de la eficiencia con la que será atendida la solicitud y baja la información a Ama de Llaves, quien se encargará de girar la instrucción a una camarista para hacer llegar el artículo. Camarista3 comunicará la entrega del artículo a Trabajador8 y éste tendrá que confirmar la recepción de la toalla con el huésped. Pero si en la entrega de la toalla, el huésped informa a Camarista3 la necesidad de un servicio de tintorería. Ella se encargará de recibir la ropa y comprometerse en un horario de entrega, confiriendo los artículos e información a la Ama de Llaves, quien será la responsable entonces de comunicarse con la tintorería, entregar y recibir la ropa e informar a Trabajador8 sobre el servicio para que se haga el debido cargo en la cuenta del huésped. Si la solicitud se hubiera originado en el departamento de Concierge, la autoridad (vista como la capacidad de mando de un departamento sobre otro, respaldado en el compromiso adquirido frente al huésped) se distribuiría de manera similar al caso de la toalla. Pero al no haberse originado ahí, Concierge tan sólo recibe la orden de Ama de Llaves de hacer el cargo y la acata. Estos serían claros ejemplos de cómo se distribuye la autoridad entre los distintos departamentos que comparten los últimos niveles del organigrama (Véase Gráfico1). Podríamos decir que en la hotelería, el trabajo en equipo se asemeja a la dinámica de trabajo bajo proyectos, aunque a veces estos proyectos son pequeñas tareas que requieren de la coordinación de distintos departamentos. 
RRHH dirige el carrito a un área alta y escondida del hotel. Se percibe una palapa a lo lejos. "Ahí es donde come Mantenimiento y Seguridad. Estamos buscando la posibilidad de tener un comedor más amplio para que todos comamos en el mismo lugar, pero todo eso son planes a futuro. Por el momento nos dividimos. Los que trabajamos directamente en el hotel (...) y los que responden a la Constructora. Aquí ellos dicen sus palabrotas y escupen. Allá abajo ya deben tener cierto comportamiento. Luego habrá villas acá también y nos iremos recorriendo, ellos lo saben. Por lo tanto no es que exista una zona específica para ellos y otra para nosotros. Digamos que todo es de todos, sólo que entre más cerca del hotel, y más apegado a nuestra operación directa con el huésped se esté, mayor compromiso se requiere del trabajador de adoptar una forma en su presencia. Ya sabes, actitud de servicio."

Bajando a la caseta principal RRHH decide revisar unas solicitudes con el CG. "Te veo en la oficina". Ya a pie, la sensación del hotel es distinta. Se despliegan entre veredas un número considerables de manzanas, no todas ocupadas, pero al menos sí trazadas. El camino principal te lleva a la caseta de acceso principal. En ésta se encuentran dos elementos de Seguridad, y desde ahí la distribución del hotel se parecia mejor. Cada vereda es un nivel mayor de la colina donde se sitúa V\&S, de forma que todas las villas son fácilmente visibles. La parte baja, es el centro de mando: oficinas de Gerencia, RRHH, Reservaciones y Ventas del hotel, áreas del departamento de ventas del desarrollo, restaurante, comedor de empleados, spa, piscina y áreas de recreación común. Sólo debajo de éste, 
como un recibidor a desnivel, se encuentra la caseta principal, estacionamiento y la recepción. Las villas están en las colinas, y arriba de ellas, en la etapa en construcción, el personal de mantenimiento. Un poco más arriba ocupando los departamentos del próximo edificio a entregar al hotel, se enuentran las oficinas administrativas del corporativo y de Sistemas. Los tráilers en la periferia del desarrollo albergan las oficinas de contabilidad del hotel, Almacén, la constructora, administradores del restaurante y a Ama de Llaves.

¿Cuál es la lógica de las áreas físicas? La misma que la del performance, la que jerarquiza los espacios: el huésped. Todo es válido si seguimos la misma línea de lealtad, mencionada anteriormente. Primero el hotel; cualquier espacio será relegado a una segunda instancia si la necesidad de atender al huésped es solicitada.

"Hasta acá nos pusieron, ¿tú crees? Supongo que está mejor. No estamos a la mitad de la operación estorbando. A veces se complica el suministro de recursos, pero se definen horarios y fechas para facilitarlo. De tal forma, aún con la distancia, no se hace tan cansado." Trabajador5 convive en el tráiler de oficinas administrativas del hotel, ahí Almacén, Contabilidad y AyB, delegan sus funciones, llevan a cabo papeleo y mantienen un contacto con proveedores. No es un lugar fijo, pero ha sido elegido mientras se construye la totalidad del hotel, para evitar el tránsito de personal ajeno al recinto. Para llegar ahí no es necesario cruzar el acceso principal. "No es que no seamos importantes [se ríe], pero no necesitamos estar de frente al huésped. Para ellos, esta parte del hotel, no existe." Trabajador5 se ha quedado pensativo. Pareciera que se dice más de 
una vez que sí es importante, tal vez así le sea más fácil creerlo. Aunque tienen una responsabilidad importante, no conocen la dinámica real del hotel. Para tomar decisiones siempre deben asesorarse de alguien inserto directamente en la operación. Si Trabajador5 no lo hace y sus requerimientos sobrepasan la normalidad hotelera, los conflictos de intereses y egos son originados. Al final siempre gana el mismo, el de la hotelería. Su conocimiento sobre la atención al huésped, el trato y la administración de los recursos, son el aval necesario para dar el gane de cualquier partida. El huésped debe estar contento, y si no representa una pérdida económica, no hay razón para negarlo.

Trabajador5 vela por las cifras, ve todo como ingreso o egreso. Los trabajadores insertos en la operación de cara al huésped. Le dan la vuelta y buscan una solución. ¿Cómo? Cuando se sucitan este tipo de enfrentamientos y el respaldo, sólo es un papel que justifica una solicitud, pero que no ha sido atedida, existe un segundo mecanismo del cual se ayudan los distintos departamentos: el carisma.

"(...) Y que ni me haga caras, porque así menos. Es que luego viene y pide las cosas de mala gana. Una cosa es el trabajo en equipo y otra cosa es resolverle los pedos a todo el mundo [se ríe y señala con la mirada a otro compañero de trabajo]. La neta, hay procedimientos, si se les fue la onda o les urge, claro que de cuates apoyas. Finalmente, la idea es que haya buen ambiente laboral y que todo salga excelente" (Trabajador2, comunicación personal, 09 de junio 2013).

La gestión de recursos es una de las principales tareas del encargado de departamento. Y el carisma es el medio a obtener estos recursos que no son autorizados formalmente. 
"Lo más difícil es que te suelten el dinero. Tú puedes solicitar lo que sea, lo importante es justificarlo bien(...) Y aún teniendo todos tus respaldos y cotizaciones, puede que tarde en bajar la autorización. Entonces, pues con la pena, le marco directo al CG y le explico la situación. Él es muy atento (...) yo siempre le sonrío y lo saludo" (Trabajadora2, comunicación personal, 29 de abril 2013).

La estructura de V\&S se ve alterada por la capacidad de sus colaboradores para obtener los recursos necesarios en sus áreas. Dicha capacidad define hasta cierto punto el nivel de influencia que tienes sobre otras áreas.

"Ella es muy buena en lo que hace. La verdad todo mundo le hace caso porque es bien buena gente. Es muy inteligente (...) la otra no, es media creída, no le sabe. Si me pide algo, mejor corroboro con alguien más. ¿Que tal si la riego?” (Trabajador3, comunicación personal, 04 de junio 2013).

Se percibe un vínculo inherente entre la habilidad social y la resolución de problemas. La inteligencia, al ser vista como la capacidad de gestionar, se relaciona directamente con el carisma. No caer bien, implica que la persona hace mal las cosas. Es decir, sufre de una pérdida de credibilidad y por lo tanto de liderazgo. Y al estar dentro de una organización con múltiples jefes, al menos de manera informal, su autoridad se reconfigura frente a los otros departamentos.

La influencia en otras áreas también varía dependiendo del tipo de recursos que los mandos medios pueden gestionar. Es decir, que se priorizan en medida que esos recursos beneficien directamente a los trabajadores. El número de trabajadores beneficiados denotará su importancia. 
"Buenas Tardes" se acerca Camarista5 por el acceso principal. Son las once de la mañana, pero Camarista5 está acostumbrada a llegar de madrugada. "¿Le tocó guardia?" pregunta Seguridad1 sin responder al saludo. "Así es esto". Se acerca a la ventanilla de la caseta, presiona su dedo medio en el lector. "Con permiso."

Todo parece distinto desde el acceso principal, la caseta tiene un aire de soberbia. El departamento de Seguridad no responde directamente al encargado del Hotel, y son tales las diferencias, que sólo han bautizado a dos elementos de este departamento, de tal forma que los demás quedan relegados al desprecio profesional de los demás trabajadores. Todo lo que tenga que ver con Seguridad, se atiende bajo estos dos elementos. Seguridad1 no es uno de estos elementos. Desde adentro de la caseta, las cosas pasan sin novedad. Los guardias se encuentran sentados o parados, viendo un monitor o atendiendo la pluma de acceso. Los trabajadores se acercan, checan llegada y salida, y eso es todo. "El dedo de Trabajadora4 nunca pasa, ella firma en esta hoja. Y desde ahí se armó el relajo, que el de él ahora no pasa, que la otra mano. Bueno, montón de excusas para no seguir las reglas." Seguridad1 se asoma hacia el hotel y da unas indicaciones por la radio. "No hay mucho que hacer ahorita." El calor no es tan pesado, hay una sombra enorme por el techo del acceso principal, pero la cercanía de la recepción con su aire acondicionado es una tentación que de vez en cuando es menester complacer. Desde la recepción, la caseta se ve muy distinta. No es la construcción la que habla, es la gente dentro de ella. Mal encarados, corveados, escupiendo al jardín de vez en vez. Seguridad1 se ha 
llevado la mano tres veces a la entrepierna, mitigando una sensación de comezón. El sudor lo hace justificable, el descaro no.

“Es por tantos químicos” -“¿La comezón?” -“¡No!, mi dedo. No tengo huellas, se me borraron. ¡Mira!" Trabajadora4 levanta la mano y Trabajadora9 desliza su dedo sobre ésta. "Está lisa." -"Está lisa y reseca. Pero no me la ves rascando todo el rato, ¿o sí? Así es esto. Primero está la imagen." Hablar de imagen, para Trabajadora4, es hablar del trabajo. Primero está el hotel. Aquél que no comprende esta lógica, no tiene cabida en el mundo de la hotelería. Cualquier personaje performado por los trabajadores de V\&S deben seguir esta prioridad, ante todo. Sin embargo, existen otras necesidades que también pueden abrir lugar a la presencia de otros espacios dentro del performance en el hotel.

En el caso de V\&S las prioridades del trabajador se encuentran depositadas en puntos de comodidad laboral, eso permitió a RRHH posicionarse en gran medida frente a otros departamentos.

"Es costumbre en el sector turístico de Vallarta-Nayarit, que en las empresas hoteleras se ofrezcan ciertos beneficios para que los trabajadores se sientan respaldados por la organización". RRHH saca una hoja del cajón de su escritorio y traza unas líneas. "Estos 'apoyos' [levanta sus dedos entre la cabeza, simulando unas comillas] recaen directamente en la apreciación, que tienen los trabajadores, del esfuerzo y gasto económico que representa laborar en un lugar en comparación con otro. El servicio de transporte y comida son unos de ellos. La alimentación y el trayecto de la casa al trabajo y viceversa recae en los costos fijos del hotel." 
V\&S en un principio se presentó reacio a otorgar estos servicios, pero la gente de hotelería ya estaba acostumbrada a obtener los beneficios y por lo tanto, "el reclutamiento fue difícil." RRHH tuvo que intervenir para explicar el contexto de la problemática dada y la importancia de acatar este tipo de solicitudes. El tema fue puesto sobre la mesa para ser analizado. Es importante señalar que no sólo los trabajadores de La Firma Hotelera se veían afectados por esta situación.

"Aún siendo un beneficio común, las otras empresas no presentaron algún tipo de iniciativa previa", continúa RRHH sin soltar la pluma. "Sin embargo, con sus respectivos medios, todas hicieron saber la opinión de los trabajadores. Esta opinión se hizo llegar a Asistente1", RRHH escribe su nombre y lo recalca con una elipse alrededor de éste (la asistente del CG, como la línea jerárquica dibujada lo estipulaba). "No se lograron avances". RRHH, haciendo uso del carisma, presentó al CG opciones de resolución sobre el tema, logrando obtener un apoyo económico para transporte de los trabajadores y un área de comedor. De la misma forma, presentó un presupuesto para el comedor, estableciendo un menú, debido a que ya en muchas ocasiones habían eliminado (o reducido) el servicio por el gasto que implicaba. Estas actividades no recaen en la gerencia de $\mathrm{RRHH}$, sino en AyB (la cual es otra empresa), por lo que la aprobación no fue tan bien recibida en ese departamento, pero "para la mayoría los acontecimientos han sido bien vistos." Eso abrió un canal a RRHH frente al CG, el cual fue percibido por la totalidad de la organización. RRHH se posicionaba como figura clave. 
La gestión de recursos es una lucha constante. No hay un presupuesto como tal, señalado para cada departamento. Por lo tanto, existe la posibilidad de ir obteniendo poco a poco los recursos necesarios para realizar las actividades de una forma más cómoda y eficiente. V\&S empezó con lo más indispensable y ha sido trabajo contiguo tanto de Gerencia junto con los encargados de cada departamento, de obtener no tan sólo los recursos, sino la infraestructura necesaria para la atención del huésped. La meta es alcanzar una holgura que permita a los departamentos trabajar con mayor seguridad. Los recursos justos siempre insertan mayor presión a la tarea. $Y$ con la diversidad de huéspedes (y por ende de gustos), siempre hay nuevas requisiciones que atender.

“¿Cómo vamos a trabajar con el estómago vacío?” replica Seguridad1. "Es bien importante, y aquí lo saben, desde que llegué me dijeron que tenía mi tiempo, siempre y cuando hubiera alguien cubriendo mi posición. Todos nos organizamos. En la plaza donde trabajaba no era así, hasta te ponían los horarios de tal forma que ya llegaras desayunado y comieras en tu casa. ¿Quién desayuna a las cinco de la mañana? Aquí la comida está muy cuidada, pero no te la niegan. Algunos ni tiempo de comer les da(...) Si dobleteas, hasta tres comidas te tocan. No cuesta, pero la pagas con las chingas que te das. Pero todo fue por RRHH si no, ni nos hubieran tomado en cuenta. Son muy pesaditos, RRHH no. Lo malo es que ella no es mi jefa. Es muy humana, muy movida."

El alimento y cualquier otro beneficio en el trabajo, no está desorientado del huésped. El espacio principal sigue siendo frente al huésped. Los demás giran en torno a éste y se hacen presentes cada vez que la audiencia principal no está 
presente. Los espacios performados a partir de personajes de los trabajadores frente a sus jefes, compañeros de trabajo y departamento pueden ser interrumpidos si la operatividad del hotel así lo necesita. Nuevamente, no desaparecen, están ahí latentes e interactúan entre sí; los desplazan consigo. Trabajadora4 prioriza el espacio frente a sus compañeros de trabajo, atiende necesidades sociales, disfruta de la atención a ellos. Pero siempre bajo la atención al huésped. RRHH atiende un espacio frente a los directivos y otro bajo sensación de anonimato para hacer sus rondines y evaluar el estado del hotel. Pero, si en su recorrido se encuentra con un huésped, desvivirá su atención en sus necesidades. Camarista1 mantiene un vínculo con la familia, el hotel lo vive en un espacio más íntimo, sin embargo no existe recelo en dejar de lado los problemas y ofrecer la mejor imagen. Es cierto, a veces no se logra, y "menos con un estómago vacío y preocupaciones en la cabeza. Hay que buscarle la forma", concluye RRHH.

\subsection{INTERACCION CON EL CUERPO HUMANO}

La importancia del espacio dentro de la dinámica del ser humano, se centra en el comportamiento de los individuos dentro de un espacio; representa la relación existente entre el espacio y los sentidos: oído, tacto y vista -principalmente(Hall, 1972). En el hotel, el performance se desarrolla, no en uno, sino en varios espacios que interactúan en el hotel. Cada uno de estos espacios, responden a la formación a partir de lo vivido: el espacio performativo. La performación del espacio puede entenderse a partir de una triada. Esta triada está conformada por las diferentes formas de concebir la construcción del espacio: ya sea como 
un espacio concebido, como un espacio percibido o como un espacio vivido (Lefebvre, 1991:33 citado en Beyes y Steyaert, 2011:49).

"Es raro... [piensa], a veces se siente como que no hay ni tiempo de pensar. Y eso que aquí (oficina) tomamos decisiones todo el tiempo, definimos cómo debemos comportarnos allá afuera, evaluamos las áreas de oportunidad y aún así todo pasa en automático, rápido. A veces el día se vive como segundos. Uno no lo siente, pero el cuerpo sí. (...) y ya no aguantas, te pesa el caminar, te duelen los pies, la cabeza, el estómago(...)" (Trabajadora5, comunicación personal, 22 de junio 2013).

En la primera concepción se presenta al espacio como algo planeado, es decir, los arquitectos construyen el espacio para que las personas se desenvuelvan en él de una forma en particular. En el espacio percibido, se hace un énfasis en las prácticas diarias para la concepción de lo que es el espacio; la rutina da forma al espacio. En la tercera concepción, el espacio es el resultado del momento de estar en un área física: el performance continuo y la interacción con el entorno.

Es una triada, puesto que no hay uno sin el otro. La producción del espacio siempre toma como referencia las tres concepciones (Lefebvre, 1991 en Beyes y Steyaert, 2011).

"Lo primero cuando entras es acostumbrar tu cuerpo." Trabajador7 ya tiene puesto el uniforme, en su playera se puede leer por la espalda: Mantenimiento. "Te dan chance de descansar, siempre y cuando sepas perderte. Porque si alguien te ve..., es como cuando eras un niño en casa de tus padres. Si no te ven no te dicen nada, pero si te ven, piensan que no estás haciendo nada y te 
piden un favor. Así es aquí. De favor en favor, nunca acabas (...) Uno está acostumbrado al trabajo pesado, pero aquí es trabajo apresurado, (...)es el estrés lo que te acaba." Trabajador7 se encuentra camino a una villa para ajustar unos detalles antes de la visita de los dueños. "Tan pronto le enseñaron a usar la cámara, las solicitudes no paran. Digo, para eso estamos. Pero todo lo quieren para ayer. No sé cómo aguantan. Bueno, sí. Se esconden. Normalmente se toman un tiempo para ellos, no todos los días, a veces el servicio no lo permite; pero, cuando es posible buscan un lugar solo para desaparecer de la vista. Todos creen que están en alguna villa, limpiando. Pero no, están descansando. Platicando con alguien o tomando agua. Ni siquiera para comer se dan un tiempo. Ellos comen en veinte minutos. Nosotros acostumbramos a comer en el triple de eso, y eso si nos apuramos." Trabajador7 pide a Camarista5 que le abra la villa, le enseña la orden de mantenimiento y se acerca a la cocina, en seguida hace un diagnóstico de lo solicitado. “¿Crees que quede hoy?” -“[levanta la ceja] ¿Qué te dije?" La triada ubica al espacio performativo como una percepción del espacio, centrada en la tercera concepción: el espacio vivido, pero que no deja de lado las otras dos concepciones. El espacio performativo va tomando forma con las interacciones de lo material, lo afectivo, lo corporal y el tiempo ${ }^{22}$.

"A veces uno pierde exactitud." Camarista5 ha dejado al responsable de Mantenimiento, en la villa, con la puerta abierta -"es por seguridad, así avisamos que alguien está adentro, y no se presta a malos entendidos" explica mientras la atora con algo-. "Sucede que con las prisas, las largas jornadas, los varios

${ }^{22}$ De esa misma forma se ve el Spacing Organization (Beyes y Steyaert, 2011). 
asuntos a atender en un día, uno puede dejar pasar algo. Para eso tenemos checklists sobre los procedimientos, pero es humano. No somos perfectos. Los ojos se acostumbran a ciertas cosas, y las das por hecho. Ves cosas que ni están. Pero es por la prisa. Así pasó con este lavabo. ¡Pues sí! Muy limpio, muy limpio, pero no sirve. Debes revisar que todo funcione correctamente(...), pero para eso se hacen los refresh. Das una pasadita al polvo que entra con el viento, que no se haya colado algún insecto, revisas que la campana no se vea rayada, que los cojines de la sala de la terraza estén colocados y que todo funcione como debe." Camarista5 mira el paisaje, se detiene unos segundos contemplando. "Y si llueve, hay que estar pendientes. No se vayan a mojar los cojines o a encharcar los suelos... en fin. Hay muchas cosas que hacer por la tarde, antes que lleguen los huéspedes." Pasa su llave electrónica por el cerrojo y entra a Ropería. Un fuerte viento del aire acondicionado golpea su frente. "Y bueno, [señala el contraste del clima balanceando sus dos manos, entre el lockoff y el exterior] si de por sí con estos cambios uno se enferma. Imagínate si llueve y debes salir corriendo a revisar todas las villas(...) Es como una casa, sea el clima que sea, hay que mantenerla en buenas condiciones."

El cuerpo de un trabajador de V\&S es expuesto a agentes climáticos que se traducen en dolencias musculares, deshidratación, enfermedades respiratorias, y problemas de piel. Camarista5 es bombardeada constantemente por un cambio de temperatura, entre el calor tropical reflejado en el pavimento de las veredas y los aires acondicionados de las villas que limpia. Trabajador7 igualmente se expone al sol y la lluvia. Esta situación no debería resultar en enfermedades, 
todos los seres humanos se exponen a ello en determinado momento. Pero en V\&S no sólo se exponen, sino que lo hacen bajo condiciones de presión. Todo es para ayer. La tensión baja las defensas de los trabajadores, y su sistema inmunológico sufre. Trabajador7 es consciente que el estrés trasgrede su cuerpo, más allá que las actividades de gran peso y esfuerzo, que está acostumbrado a realizar.

"El cuerpo es sabio, se seda mientras estás en la talacha. De verdad, aún cuando apenas estás por resfriarte, el cuerpo aguanta hasta que termina tu turno. Normalmente se enferman en vacaciones. Parece que cuando estás por descansar, el cuerpo lo sabe y baja la guardia. Es lo más común. Saben que mañana es su día libre y los ves que salen ya moqueando. No se vale, porque uno no logra disfrutar sus días, pero de que descansas, descansas. Aún así es muy raro que me falten por enfermedad." (RRHH, comunicación personal, 14 de julio 2013).

"No a todos les pesa. Algunos ya están acostumbrados." Camarista5 revisa el pintarrón de Ropería, donde le han dejado algunos pendientes. "Todo depende de cómo lo manejas. Cuando le agarras el gusto, el cuerpo va adaptándose a tu ritmo de trabajo, a los horarios, a la locura [ríe apenadamente]. Es común que por querer acabar. Por desentenderte de algún pendiente. No pares hasta terminarlo, entonces no comes a tus horas, o no descansas, no tomas agua. (...) y te duele (el estómago), pero vas enseñando el cuerpo a sobrellevarlo. No con mala intención de lastimarnos, más bien sin querer, sucede." El cuerpo se adapta a una idea de pretensión. El trabajador de V\&S adopta personajes. Su cuerpo también. A un nivel más íntimo el cuerpo padece dolencias, fatiga, y 
sobrecarga; en un nivel público, el cuerpo presenta equilibrio, fortaleza y rendimiento: una actitud de servicio.

“(...) de las vías respiratorias y del estómago. Lo más común son resfriados, deshidratación, insolación o úlceras. Hay muchos malos vicios, como iniciar el trabajo sin desayunar, o el café en ayunas para aguantar la jornada. Subirle al aire acondicionado cada vez que se pueda. No usar bloqueador. Por más que hagamos consciencia, nos las volamos." (RRHH, comunicación personal, 14 de julio 2013).

Es difícil admitir fragilidad. El trabajador de V\&S utiliza sus dolencias para jactarse del gran trabajo hecho, pero no para atenderse. Un cuerpo enfermo, es un cuerpo que no aguanta el ritmo de la hotelería. Un cuerpo que aún enfermo logra mantenerse de pie y atender a la gente, es un cuerpo que se ha ganado un descanso.

“(...) es raro quien te lo pide, mas bien yo los obligo. No pueden estar así en el hotel, contagian, o peor aún, se les puede complicar." (RRHH, comunicación personal, 14 de julio 2013).

Un trabajador de hotel no pide el descanso, hace notorio el estado en que se encuentra, lo utiliza para legitimar su posición dentro de la élite, y entonces, sólo entonces, le dan su descanso. Por lo tanto, el trabajador de V\&S compromete su cuerpo en el personaje que está performando. Se "dramatiza" en el cuerpo para dar credibilidad del esfuerzo orientado hacia el trabajo (Goffman, 1959:20). A falta de poder hacerlo evidente, de manera individual, en otros aspectos de su vida. Sólo así le pone valor a su trabajo frente a los demás. Por ello, si bien está perdiendo autonomía en su capacidad de decidir sobre los límites de su 
rendimiento. El trabajador consigue un nivel de autoconocimiento, sobre el rango de proyección que tiene su cuerpo hacia el exterior.

Entonces, ¿cómo sabes cuando alguien está exagerando una condición indispuesta, para obtener reputación o un permiso de descanso? "No se sabe. Nos obligan a atendernos en el seguro, es la única manera de justificar una falta. O te los tomas de tus días solidarios, sea lo que sea, no te conviene. Si faltas, alguien aprende a hacer tu chamba, o se queda con las propinas, o se gana en atenciones a los huéspedes, o se gana la confianza de los jefes... ¡Uy, no! Es que esto se vuelve un vicio. Al mismo cuerpo, le hace falta esta forma de trabajar, se acostumbra." Camarista5 está trabajando en los dos refresh pendientes. Sus pasos parecen contados; la manera de revisar los baños, el barrer la entrada de las villas, al correr la cortina y hasta el volver a tender una cama, todo lo ha hecho como robotizada. Domina los procedimientos, sus muñecas se giran con suavidad, y los dedos conocen la presión justa para evitar las arrugas. No hace ruidos innecesarios, su paso es suave y casi silencioso.

Al terminar, regresa a ver como va Trabajador7. "Te acostumbras tanto, que de pronto todo mundo se te hace lento."

"Cada cultura organiza el espacio de forma diferente a partir de un substrato animal idéntico, el <<territorio>> (Winkin,1984:93)". Para Camarista5, el cuerpo es esencial, por muy obvio que suene, el cuerpo es presencia. La ausencia no es sólo un medio para obtener un descanso. Si el cuerpo no está presente, si hay una ausencia de cuerpo, no hay una continuidad del rendimiento laboral. Se produce algo similar a la "comunicación impropia" de Goffman (1959:91). El 
cuerpo es una manera de marcar el territorio, y de asumir convicción. Si el cuerpo no está, se cae en la posibilidad de perder a ese alguien que le crea, o frente al cual representar su personaje, de la manera en que lo ha venido haciendo.

Si el trabajador compromete todo el cuerpo en la personificación de un personaje, el cuerpo es el medio para la credibilidad. "Vivimos por inferencia" (Goffman 1959:4) y como tal, el cuerpo es ocupado para el intercambio de percepciones. Se utiliza el cuerpo con cierta habilidad para obtener un control de la conducta del otro (Goffman 1959:8). Camarista5 utiliza su cuerpo para demostrar productividad, la forma tajante de hablar, coincide con una presencia amenazante de quien se considera a la altura de su rol designado. En consecuencia, proyecta una definición de lo que considera debería ser la actitud de servicio. Implícitamente demanda se le trate y valore de determinada forma. "Utiliza estrategias y tácticas para proteger sus propias proyecciones" y "salvaguardar la impresión fomentada" (Goffman, 1959:10-12). El cuerpo permite a Camarista5, proyectar el nivel de seriedad con la que desea ser percibida. "Yo creo que hoy no queda" Trabajador7 sigue buscando una forma de solucionar el problema del lavado. "Hace falta una pieza". Camarista5 no está satisfecha con esa respuesta. Su cara proyecta una seriedad impecable. "¿Y si tomamos la pieza del lavadero del lock-off?, ¿serviría si ocupamos esa pieza, y ya mañana temprano, con más calma repones la de Ropería?" Su cuerpo se ha encorvado hacia el frente, inclina la cabeza y se mantiene en espera de la respuesta de Trabajador7. Casi pudiera decirse que de manera lejana, el cuerpo 
de Camarista5 está depositando toda su seguridad en el cuerpo del otro. Su cuerpo denota confianza en las habilidades de Trabajador7 y su mesura en la cara demanda de Trabajador7 una respuesta clara, honesta y comprometida con el trabajo.

Camarista5 demuestra su capacidad de ubicarse a través del cuerpo en un espacio más íntimo frente a Trabajador7, pero a una distancia pertinentemente lejana, para que no se confunda con redención o imploración. El cuerpo de Camarista5 es capaz de personificar diversas distancias interpersonales. "Hall propone (...)una escala de las distancias interpersonales. Considera cuatro distancias: íntima, personal, social y pública. Cada una de ellas comporta dos modalidades: próxima y lejana (Winkin,1984:93)". "No sé si sea la misma." -“¡Te la traigo!"

"Camarista5 tiene ese tacto que se necesita. Confío mucho en su desempeño. Busca por todas las formas resolver el trabajo, y la gente lo sabe. Sus compañeros la respetan. Es una mano derecha." Ama de Llaves cierra el cajón privado de su escritorio y exhala. "Con gente así de comprometida, uno puede hacer mejor su trabajo."

Para los trabajadores de V\&S el cuerpo es su tarjeta de presentación. Facilita el desempeño de sus actividades, pero en mayor medida el de sus interacciones con los demás trabajadores. El cuerpo les permite exteriorizar el compromiso con sus actividades y con las prioridades del hotel: el cuerpo es el vehículo para personificar la actitud de servicio. Es curioso, pues aunque el cuerpo les permite atraer la atención de sus compañeros y jefes a su compromiso, también les 
permite situarse en una posición anónima frente al huésped: las huellas de Camaristo1 en la cocina, el tono de voz firme y dulce de Trabajador4, la capacidad de Bell-boy para hacerse invisible junto al huésped cuando así se le solicita implícitamente, el comportamiento e imagen que tanto reitera Trabajadora4, la misma precisión de Camarista5 con su andar silencioso y la necesidad de ser uniformes en su aspecto puntualizada por Ama de Llaves $-\mathrm{y}$ RRHH-. Todo está pensado para estar y no estar a la vez. El cuerpo de los trabajadores de V\&S se amolda en una lógica de omnipresencia. Siempre están, pero no deben verse. Al menos que se les necesite. Nada en su cuerpo debe ser lo suficientemente llamativo para distraer al huésped de su ilusión vacacional. El cuerpo dota de sentido estas intenciones, y por ende, legitima la dirección de la interacción.

Las interacciones, resultado de los roles adoptados por los trabajadores frente a los distintos públicos, van formando los programas (Scheflen, en Winkin, 1984) que a su vez formarían el espacio performativo organizacional. En otras palabras, el cuerpo le da vida a un personaje, y estos personajes utilizados por los trabajadores para interactuar con los públicos, son participantes de la performación de los espacios de V\&S. Se performa un espacio principal para el huésped, un "escenario" (Goffman, 1959); y otros tantos más a su alrededor, "detrás del telón". 


\section{CAPÍTULO 4}

Interpretación de la Realidad:

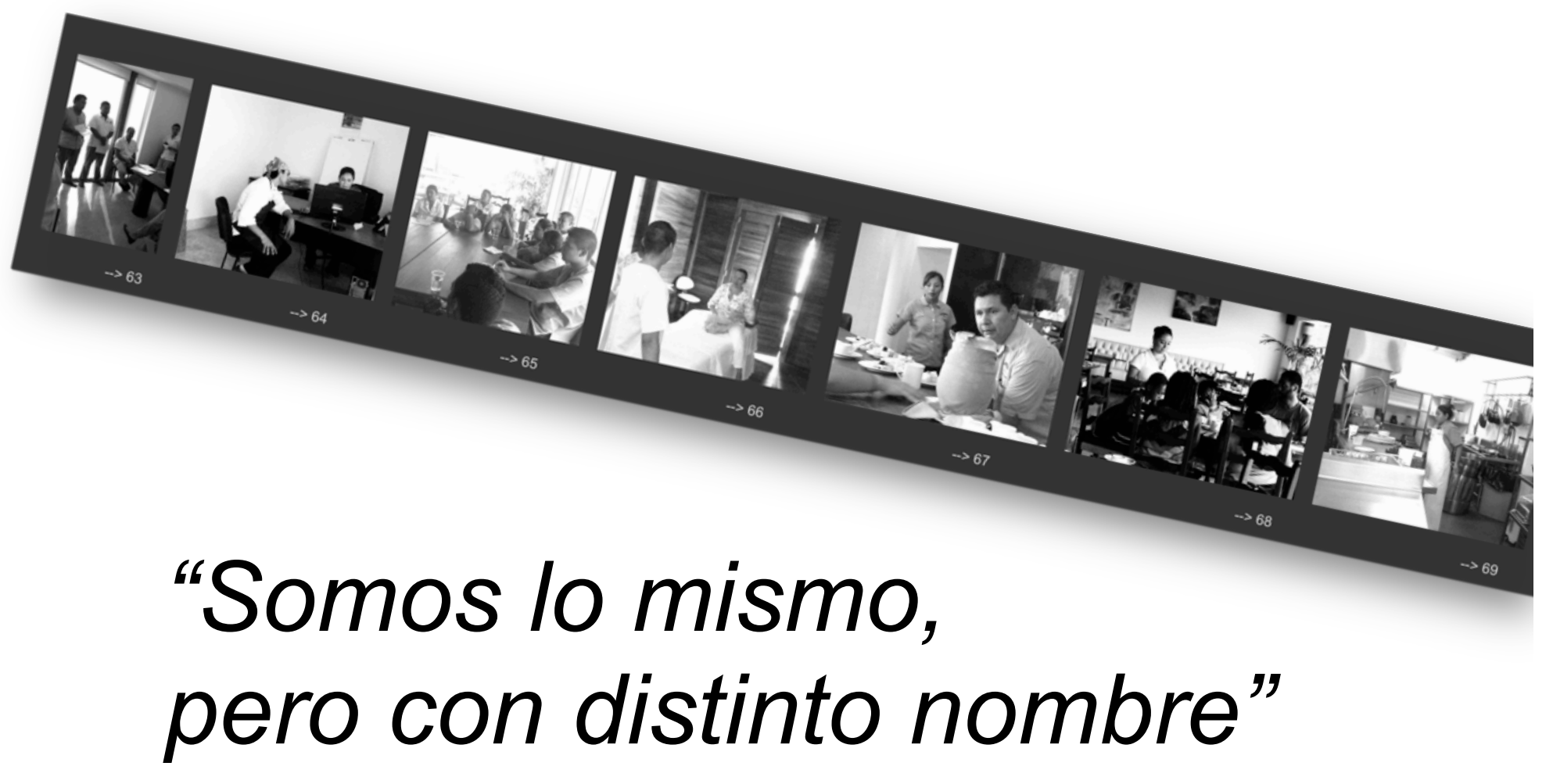




\section{CAPITULO 4. INTERPRETACIÓN DE LA REALIDAD}

“¿Hablas conmigo?” No obtiene respuesta. Da por hecho, que no es así y sigue comiendo. -“¿Está en el chicharito?”, pregunta Camarista3 mientras levanta su bandeja. "¡Sí!" -"Al parecer también a nosotros nos quieren dar de esos”. -“Ay! Pero se ven bien estorbosos." Camarista1 se apura a comer el último pedazo de fruta. Se pasa el bocado al mismo ritmo que deja la mesa y apila sus trastes con los de Camarista3. "Pero va a ser más fácil localizarnos entre todos." -"Nos van a volver locas con tantas voces en el oído”. -“¡Depende!” -“¿De qué?”

El espacio no es únicamente un lienzo, es la totalidad de la pieza artística y sus interpretaciones -producción y evolución-. De acuerdo con Montaño y Rendón (2000:69), "la organización no es vivida cotidianamente como un lugar exclusivo de trabajo, sino que en su construcción social participa un conjunto de experiencias -reales e imaginarias-. Que le otorgan a la organización una multiplicidad de interpretaciones que nos obligan a pensar en ella como un objeto de múltiples reapropiaciones semánticas, una especie de epidemia, en sentido sperberiano ${ }^{23 "}$.

Los trabajadores de V\&S utilizan sus sentidos para abrirse camino en el hotel. Las camaristas pueden o no gustar de la idea de utilizar las radios en su trabajo. Pero si se les obliga, le encontrarán un sentido que se ajuste a la manera en que viven el hotel. Podían mantener una posición renuente por unos días. Pero, al final se ajustará a la dirección prioritaria del hotel, el servicio al huésped, y las

${ }^{23}$ Los autores hacen alusión al texto de Dan Sperber (1997) El Contagio de las ideas, Odile Jacob. Paris, 1996. Donde se habla de una propagación múltiple, eficaz, libre y constante de ideas, las cuales conforman la cultura en una región. 
camaristas harán lo propio. Las percepciones de las camaristas, desembocan en apreciaciones e interpretaciones de éstas, cargadas de un juicio que avivan un comportamiento específico en el espacio (Hall, 1972).

En el cúmulo de espacios que se viven dentro de V\&S, las interpretaciones alinean el performance a seguir y la reinterpretación misma. V\&S no se vive de una sola forma, no hay un solo punto de vista. Como en el arte, la interpretación del hotel depende de quién la vea, y en la socialización, las interpretaciones convergen para darle sentido a la organización. Supongamos a la organización como una pintura abstracta. El estilo de la pintura implica de inicio que tiene un fin interpretativo específico por parte del autor, pero cada persona que observe la pieza en cuestión observará de manera selectiva ciertos elementos que destacan a su parecer y los utilizará para construir su interpretación. Entonces, diversas interpretaciones son efecto de una misma pintura. Lo que es igual, es percibida como una distinta pintura por parte de cada uno de los observadores.

La subjetividad de la pintura, depende de la manera en que el observador relaciona los elementos del cuadro, y del momento específico en el que el sujeto se encuentra al observar la pieza (su humor, ubicación, status, ideología, y más). Trasladando este ejemplo a V\&S, la relación entre elementos puede hacer alusión a las relaciones humanas que se estrechan al interior del hotel. Estas relaciones humanas participantes pueden ser vistas como un "sistema de actividad interdependiente" (Smircich y Stubbart, 1985) el cual, a su vez, depende del contexto en el que está inserto -la práctica hotelera, la dirección del proyecto de $\mathrm{V} \& S$, la relación con las otras firmas, el suelo nayarita y su cultura 
cora, entre otros- y que influye en la configuración misma de éste: la lógica del performance.

Cada organización es diferente, en especial porque implican relaciones entre seres humanos, pues éstas son dinámicas y en ellas intervienen múltiples factores de tipo subjetivo que se deben tomar en cuenta, para cualquier análisis. En palabras de Smircich y Stubbart (1985:727): "la organización se define como el grado en que un conjunto de personas comparten creencias, valores y supuestos que fomentan el refuerzo de las interpretaciones de sus propios actos y los actos de otros".

Los trabajadores, como los observadores de la pintura, perciben en los actos resultantes de las relaciones humanas que participan dentro de $V \& S$, un sentido particular de la dinámica organizacional, el cual es contrastado socialmente para llegar a un consenso con otros trabajadores, resultando en interpretaciones compartidas, que a su vez serán referencia para nuevas reinterpretaciones del mismo hotel. Y así formar esa cadena de reinterpretaciones a la que hacen alusión Montaño y Rendón (2000:69). La pintura abstracta no es interpretada de igual forma por el mismo observador, la pintura emana de sensaciones al observador que utiliza para estrechar otro tipo de vínculos entre los elementos de la pintura, que resultarán en una reinterpretación de la pieza, la cual, a su vez, sensibilizará sobre la misma línea pautada (Goffman, 1959) pero de distinta manera, los sentidos del mismo observador, y así sucesivamente. V\&S se vive a partir de una serie de reinterpretaciones de los actos resultantes de las 
relaciones que se van afianzando con los elementos de la organización.

Por ello, para Czarniawska (2004) los actos no son un suceso terminado y separable de la realidad, mas bien refieren a un contexto y son partícipes en una continuidad. El espacio y tiempo toman una concepción distinta en el análisis organizacional, donde se conciben como performative concepts (Beyes y Steyaert, 2011:47); dentro del espacio y tiempo existen pequeñas partículas que los constituyen, son causa y efecto de la realidad organizacional.

\subsection{ESPACIO-TIEMPO}

Para Scheflen (en Winkin, 1984) el contexto sólo se concibe como un marco que acota las interacciones de los individuos; el spacing va más allá. Los espacios robustecen su importancia al aportar sentido a los actos humanos, y tienen otros elementos, aparte del área física, que inciden en su propia construcción y la de los individuos dentro de éste. Es una relación simbiótica. Las relación entre el Trabajador3 y las camaristas no puede existir salvo dentro de la concepción de un espacio (Lefebvre, 1991 en Beyes y Steayert, 2011:48).

"Es para que el huésped no escuche," explica Trabajador3, quien se quita el chicharito del oído. "Lo malo es que no te deja ni comer. Pero, jte imaginas que el huésped se entere de todo lo que decimos por la radio!" Trabajador3 retoma su comida, y se vuelve a colocar el chicharito. Las camaristas tienen su respuesta. Puede que traer la radio de un lado a otro les estorbe en sus actividades, pero seguramente les resuelva la manera de lidiar con algunos 
asuntos. Sin duda alguna, mantener la operación oculta, es un beneficio para ellas.

"En otras palabras... ¡Te aguantas!" Camarista3 se burla. Reconoce en la respuesta de Trabajador3 una razón pertinente para ajustarse al cambio. La coordinación del hotel depende de una tecnología como medio de comunicación. Ésta debe ser accesible y sutil para no llamar la atención del huésped. La tecnología permite a los trabajadores de V\&S mantener el espacio primario, el "escenario" del hotel, para que la audiencia no se de cuenta del esfuerzo, detrás del telón. El huésped debe mantenerse ausente de este espacio. "Hay cosas que el huésped, simplemente no debe oír. Por la radio nos avisamos las fallas, se giran instrucciones continuas sobre mantenimiento y proveedores. $Y$ las mismas palabras que utilizadas, no van con la apariencia que se debe tener frente al huésped. No somos tan groseros, pero de vez en cuando se nos salen unas palabras o bromas".

En la voz de Trabajador3 se percibe una molestia cuando habla de la presencia frente al huésped. Ya existen demasiadas presiones en el escenario; y sin un espacio alterno para exteriorizar la tensión, el trabajador expondría sus quejas y comentarios frente al huésped. "El huésped siempre tiene la razón”, y cuando no la tiene, se le hace creer que sí. Cada jefe de departamento cuenta con un radio portátil (operativos) o bien una línea telefónica (administrativos) que los mantiene en constante comunicación. Por ende, el flujo de información es más dinámico y hasta cierto punto caótico. Esto es debido a que los radios deben estar siempre encendidos y lo que se dice en estos aparatos móviles son "conversaciones 
sobre la puesta en escena ${ }^{24}$ (Goffman, 1959)", lo referente a la logística del hotel, y más específicamente a los problemas, faltantes y situaciones que requieren de una solución pronta. El huésped debe ser alejado de este contexto y por ello, se hace uso de audífonos -el chicharito- que permitan informar lo que sea necesario sin que el huésped escuche.

Entonces se ocupan los otros espacios para vociferar las contrariedades, armar las respuestas adecuadas, destensar los músculos y dejar en claro la verdadera postura del trabajador. La ausencia del huésped en los otros espacios es un medio de equilibrio para el performance de Trabajador3. Para Camarista1 no es sólo la ausencia del huésped, sino de los compañeros de otros departamentos. "Pero de todos modos, todos se enteran. Mejor te marco." -"Pues, mas bien es cuando no sabes en qué villa estoy." -"Ya me vi, enterando a todo mundo. 'Camarista3, no hay papel. ¡Ayuda!', jay no, qué horror!.” Camarista1 toma su delantal y juega sus manos con éste, como si fuera un rebozo. "Por eso mismo el chicharito [se burla Trabajador3, hablando al aire], hay cosas que el huésped, simplemente no quiere saber". -“Ni el huésped, ni los demás”, responde con vergüenza Camarista1. Trabajador3 sigue oyendo una conversación con su oído izquierdo, fija la mirada en el salsero de la mesa cuando presta más atención. Entrecierra los ojos. “¡Uy no!, y si escucharan sus apodos...”-“Los apodos están

24 Goffman (1959:96) plantea que "cuando los miembros del equipo no están ante el auditorio, la conversación gira a menudo en torno de los problemas de la puesta en escena. Se plantean cuestiones acerca del carácter de la dotación de signos; los miembros reunidos sacan a luz y «esclarecen» las actitudes, líneas de conducta y posiciones; analizan los méritos e inconvenientes de las regiones anteriores disponibles; consideran el tamaño y el carácter de los auditorios potenciales para la actuación; cambian ideas acerca de las disrupciones acaecidas en actuaciones anteriores y de las disrupciones que podrían producirse en el futuro; transmiten noticias acerca de los equipos de otros colegas; desmenuzan concienzudamente la acogida brindada a la última actuación, en una ceremonia que suelen designar con el nombre de «autopsia» o examen post mortem; suavizan las heridas y refuerzan la moral para la próxima actuación". 
prohibidos por el reglamento [interrumpe Camarista1 con altanería], compañero." -“A los huéspedes no. Y no se los decimos en su cara. Pero es que luego te chocan. Y uno ahí con su carota de pen... [ponen cara de sorpresa las camaristas. Abren los ojos exageradamente y sonríen] Necesitas sacar el coraje de alguna forma." La actitud de servicio, implica una supeditación ante el huésped. Mal hablar, burlarse de lo escuchado, de lo vivido con el huésped, permite a Trabajador3 compensar ese sentimiento de subordinación que se impone así mismo. "Cuando los miembros de un equipo pasan al trasfondo escénico, donde el auditorio no puede verlos ni oírlos, suelen detractarlo de una manera que es incompatible con el tratamiento cara a cara que dan a dicho auditorio. En las actividades que implican prestación de servicios, por ejemplo, los clientes que son tratados con todo respeto durante la actuación suelen ser ridiculizados, caricaturizados, difamados, maldecidos y criticados cuando los actuantes están entre bastidores; aquí también pueden elaborarse planes para «engañarlos», o emplear «ángulos de ataque» contra ellos, o «bajarles los humos»" (Goffman, 1959:82). En los espacios velados al huésped, Trabajador3 declara que la actitud de servicio no lo define. No siempre está de acuerdo con ésta, y le genera conflictos en su cabeza: molestias. En la interpretación de su realidad, para los trabajadores de V\&S, la priorización de un performance de servicio al huésped, no implica una personalidad o identidad, sino una medida (recurso) para asegurar su satisfacción hacia su realización profesional.

Los trabajadores de V\&S navegan entre los distintos espacios, tanto como la presencia de huésped lo permite. Su interés por vigilar que el huésped no tome 
conocimiento de la logística, es una forma de asegurar que sigue siendo su territorio. "Cada cultura organiza el espacio de forma diferente a partir de un substrato animal idéntico, el <<territorio>>" (Winkin,1984:93). Ahí el huésped no es venerado, el trabajador expresa sus observaciones sobre la operación y sus compañeros se identifican. Ahí no están solos. El espacio frente al huésped requiere de una unidad de los trabajadores. La unidad del equipo, evita romper con el performance de éste. "A pesar de la presunción de que todo cuanto dice el actuante concordará con la definición de la situación suscitada por su actuación, durante la interacción está en condiciones de transmitir muchas cosas ajenas al personaje, y transmitirlas de modo tal que impida que la totalidad del auditorio advierta que se ha transmitido algo que no concuerda con la definición de la situación. Las personas que tienen acceso a esta comunicación secreta establecen una relación de connivencia mutua respecto del resto de los participantes. Al reconocer entre sí que ocultan a los demás miembros del auditorio secretos pertinentes, admiten también que la apariencia de sinceridad que mantienen, la apariencia de ser solo los personajes que proyectan oficialmente, no es más que una representación" (Goffman, 1959:157).

La información necesaria para esta connivencia del equipo, los referentes, son expresados continuamente a partir de estos medios ocultos, o ausentes de la percepción del huésped. La tecnología entonces, se ocupa tanto agilizando procedimientos como el check-in a través de un software, pero también ocultando cualquier situación crítica que pudiera alterar la sensación de tranquilidad y recreación dentro del hotel por medio de los audífonos del radio, y 
coordinando los esfuerzos del equipo con las líneas telefónicas, medios electrónicos y aparatos de radio móviles, que a su vez agilizan la atención de cualquier contingencia suscitada. Los trabajadores de V\&S le llaman mejorar la experiencia del huésped. Aunque este tipo de actividades se asimilan más a la acción de solaparse.

Como lo advierte Camarista1, la connivencia no es sólo frente al huésped. Aducir a sus compañeros de trabajo como todo mundo, refuerza una concepción, que en determinados temas, los otros departamentos o amigos no tan íntimos, también son objetos de información oculta. Nuevamente se plantea una diferenciación intrapersonal. En este apartado, el interés no se enfoca en la diferenciación como tal, sino en los recursos utilizados para perpetuar este espacio-tiempo diferente. Los códigos al hablar, la postura adscrita a determinado personaje, alargan la sensación de situarse en un momento específico, donde la lógica es disímil a otros.

Existe sensación de libertad dentro del trabajo, en la medida que aprenden a administrar el tiempo y obtener holguras entre los diferentes espacios. El ocio, no es visto como una perdida de tiempo, ni una supuesta improductividad (Munné, 1980:58). La oposición entre el trabajo y el ocio se interpreta como un beneficio obtenido por la experiencia adquirida en el giro hotelero. La Ama de Llaves puede tomarse un momento para platicar de su vida personal con una compañera de trabajo en su oficina, porque ha adelantado el trabajo urgente del día y mañana puede llegar temprano para terminar los reportes antes del briefing. La presión ejercida por el espacio-tiempo recae, como se ha visto, en la 
formación académica de los trabajadores de turismo. La empresa obtiene ganancias de este adoctrinamiento, pero no ha hecho más que sacarle ventaja a la influencia ejercida por el mismo grupo de licenciados en turismo sobre aquéllos ajenos a este giro. La lógica es replicada de esta forma y su adhesión dota de reconocimiento del equipo de trabajo. Las relaciones sociales se trastocan (De la Garza, 2010; Neffa, 2010) y el hotel se concibe como una organización que no es vivida sólo como un trabajo (De la Garza, 2010; Montaño y Rendón, 2000), sino como una vocación. El tiempo para los trabajadores de este hotel lo es todo. Es una "inversión de vida", Así el espacio-tiempo de V\&S está siendo performado por otras actividades relacionadas al no-trabajo y en ellas se encuentran elementos que cobran sentido (dirección) y complementan el acto social de la propia organización.

\subsection{VÍNCULOS Y REACCIONES}

Con su primera etapa concluida e inaugurada en el año 2012, V\&S ha tenido un crecimiento constante a través de la aceptación de sus clientes y empleados. Siendo el personal hotelero, o mas bien la formación de ellos, quienes han logrado direccionar y resolver el servicio, junto con las modificaciones que se han realizado paralelamente alrededor de la idea original del desarrollo: su performance, a partir de la manera en que ellos interpretan el trabajo, ha dirigido la proyección del hotel. 
"Somos lo mismo, pero con distinto nombre. Somos una misma compañía, pero cada servicio tiene diferente nombre, somos diferentes firmas por así decirlo" (Gerente, comunicación personal, 27 de abril 2013).

La manera en que los trabajadores de V\&S se relacionan con sus actividades laborales, permean las interacciones entre ellos con sus diferentes audiencias. Las expectativas y el valor dado al trabajo se relacionan estrechamente con el vínculo forjado con los espacios del hotel. "Cuando hablamos de la generación de vínculos no estamos hablando de una única relación, de un prototipo de vínculo perfecto de las personas a las organizaciones. Las personas nos vinculamos de muchas maneras y por muchos motivos diferentes a las organizaciones. La vinculación contractual (el salario), emocional (a unas personas, a un colectivo...), a una misión, a una organización, a una forma de hacer, a la generación de determinadas transformaciones, a la posibilidad de participar en un proyecto conjunto... Todos estos motivos son legítimos, y es importante conocerlos y respetarlos(...), se trata de sentimientos de pertenencia que tienen un alto componente subjetivo, variando a lo largo del tiempo, pudiendo tener diferentes intensidades y formas de expresarse. $\mathrm{Y}$ como todos los vínculos generados en un sistema, estos se mantienen, evolucionan, se van transformando y se desarrollan en respuesta a esta naturaleza de interacciones y su percepción" (3SBIZKAIA, 2012). "Somos y no somos. Somos del hotel, pero a la vez no". Víctima de la tercerización, Trabajador7 externa su sentimiento de rechazo. La manera en que interpreta su realidad como parte de V\&S, dimensiona vínculos con los espacios performados en el hotel. "No es lo mismo. El trabajo lo disfrutan, pero no es de la misma forma que la gente normal. 
¿Cómo se dice? [piensa] Bueno, no sé. Pero disfrutan la presión. Como que ya saben que de eso se trata. Entre más presión, más contentos los ves. Eso sí, quejándose, pero lo disfrutan. (...)Yo me quejo, porque no lo disfruto." Perteneciente a mantenimiento, Trabajador7 vive lo mismo que los colaboradores que responden a la constructora, la pagadora, jardinería y vigilancia, son empresas que ya existían en el mercado y fueron contratadas como prestadoras de servicio, pero no conocen del ejercicio hotelero, o al menos no de forma interna. La operadora del hotel también es una empresa contratada bajo esta lógica, pero como se ha mencionado su representación en utilidades es tal, que cuentan con una posición ventajosa en V\&S. Por lo cual, DG, CG y DOH depositan una singular confianza al Gerente del Hotel de Villas \& Spa (GH). Identificada en la libertad que él tiene para la toma de decisión. Debido a ésta clara delegación de autoridad, GH es la primera persona a informar sobre cualquier asunto de la operación de $\mathrm{V} \& \mathrm{~S}$, aunque no formen parte de la operadora del hotel. "Bonita te vas a escuchar, diciendo esas cosas por la radio." -“Déjala que la oiga GH.” -“¿También tiene radio?” Camarista1 y Camarista3 han quedado sorprendidas con las respuesta de Trabajador3. "Pues claro, si no ¿cómo está al tanto de la operación?” -“Ay no, definitivo no es opción para nosotras. Que oiga mejor a ustedes y los de la construcción con sus leperadas. A una, mejor que la dejen trabajar." -“A mí, no me caería nada mal enterarme de lo que pasa allá afuera. Aquí adentro me aburro un poco cuando no hay servicio." Cocinero1 se introduce a la conversación, como siempre lo ha hecho: sin inhibiciones. Durante toda la conversación ha estado sirviendo la comida de 
los compañeros que van Ilegando. El perfecto cálculo de sus cucharadas, ubicado en la memoria de los ligamientos de su muñeca derecha, le permite enfocar toda su atención en la plática ajena. Cocinero1 es un máster en el desmenuzado de la conversación múltiple. Lo sabe, y le saca provecho. "Así me pueden avisar a qué hora van a bajar, para que no estén esperando a que se desocupen lugares. Luego estamos más apretados, y ya de por sí hace mucha calor." Quienes lo oyen, no le encuentran sentido a su comentario. "Lo que quiere es chisme...” aclara Camarista1. -“... y no me caería nada mal”, interrumpe Cocinero1. "De todos modos siempre me entero. Si no, luego le pregunto a mi jefa, la Licenciada." Esto último, lo dice en tono de presunción y seguido de un par de risas, para reafirmar lo dicho.

Cocinero1 forma parte de AyB (Alimentos y Bebidas), este departamento está a cargo de un administrador (GR), quien estableció un nuevo restaurante en este hotel, pero que ya tiene varios restaurantes a su cargo, en la zona de VallartaNayarit. Como el restaurante, la Inmobiliaria también es una empresa nueva ubicada dentro de V\&S. Ésta fue creada con el único fin de vender las villas de este desarrollo. Finalmente, en la operación todas las firmas responden al DG, dueño de V\&S, a su mano derecha, el CG, cuyas oficinas se encuentran dentro del desarrollo de V\&S y al DOH, responsable de la operatividad del Hotel y el SPA. Es importante recalcar, que los únicos que se encuentra físicamente supervisando el desarrollo son CG y GH. Tanto DG como DOH y GR administran otros negocios, lo que los tiene en constante movimiento y con residencia en otras ciudades del país. 
Aún siendo parte de un departamento ajeno a la gerencia de $\mathrm{GH}$ y sin que su puesto tenga algún contacto directo con el huésped, Cocinero1 se considera parte del equipo del hotel. Llama su jefa a RRHH (cuando lo es GR) y debido a su acercamiento con todo el personal, por su ubicación en el comedor, disfruta de las anécdotas que circulan en su alrededor, se las apropia y se manifiesta ilusionado de sentirse parte de la operación. "Esto no es como otros trabajos. Porque se requiere de muchas ganas de atender. Aquí nos ves muy metidos en lo nuestro. Claro, cada quien en lo que sabe, ¿no?, para lo que nos pagan. Yo siempre he trabajado en la cocina, antes tenía mi lugarcito, pero pues no tenía seguro [médico]. Aquí me encargo de alimentarlos a todos, y mantenerlos contentos para que hagan su chamba. Esto de la atención a los visitantes que se hospedan llena mucho. Es bonito nuestro trabajo(...) somos como una gran familia."

Apoyados en esta estructura, ser parte de V\&S, no significa quién te paga (pues la mayoría recibe sus ingresos de la pagadora, aunque pertenezcan a diferentes empresas), ni a qué firma perteneces (pues quien te contrata, no siempre es las la autoridad). Ser o no ser parte de V\&S refiere a tu introyección de la hotelería como vocación. Cualquier trabajador, de cualquier departamento será considerado de V\&S, cuando su actitud de servicio comulgue con la de la hotelería. La profesionalización, entonces, no es contundente en el momento de forjar un vínculo hacia el hotel. 
Trabajador7 trabaja en el hotel, pero aún no es parte de él. Sus compañeros lo consideran un trabajador staff, aunque estrictamente todos lo sean; y él a su vez se considera apartado del hotel, pues su chamba sólo es reparar desperfectos de las villas. Por su parte, Cocinero1 se ve así mismo como pieza importante en la logística de V\&S, pues él alimenta al personal. $\mathrm{Y}$ en un sentido más paternalista que de compañero, Cocinero1 se siente fuertemente ligado a V\&S: Parte de la familia. Todos somos el hotel porque para el exterior son una sola empresa. Pero no todos son parte de éste, porque no todos saben servir, ni cual es el objetivo final de sus esfuerzos. Poéticamente, el huésped es la última autoridad; terrenalmente, V\&S va definiendo la autoridad de su operación, de acuerdo a su contexto.

Después de DG, CG, DOH y $\mathrm{GH}$, existe una quinta figura clave dentro de la operación del Hotel, que más que ser figura de autoridad, su papel ha sido el de filtro de información: Asistente1. El flujo de información es obligatorio para la autorización (por lo tanto del respaldo) de la toma de decisión de los distintos departamentos y firmas que se fusionan en V\&S. Asistente1, mano derecha del CG, funge más allá que como una asistente administrativa. Debido al gran número de trabajadores que operan dentro del desarrollo, no tan sólo en el área hotelera, el CG ha ido delegando funciones cada vez mayores a su asistente. Tal es el caso, que todo tipo de reporte, requisición e información que deba subir a la alta gerencia, debe pasar por ella. Asistente1 determina la forma y tiempo en que esa información debe llegar a sus manos, así como la importancia y por lo 
tanto, brevedad con la que será atendida. Su supervisión y funciones no son vistas como la de una asistente, sino como la de una autoridad que da su visto bueno, aunque éste no sea su cargo real. Asistente1 no tiene una formación en turismo. La lejanía de su teoría con la práctica hotelera, hace padecer sin número de conflictos entre los departamentos, que sólo llegan a resolverse cuando se integran todas las partes afectadas y se expresan los malos entendidos.

“(...) Innecesario, es la única forma de verlo. Es muy buena en lo que hace: atrasar las cosas para no soltar rápido el sí [el dinero]. Pero, es que es muy desconfiada. Como no sabe, no nos cree, (...) y a explicarle con manzanas" (Trabajadora2, comunicación personal, 29 de abril 2013).

La confianza en el trabajo en equipo es la única posibilidad para sobrellevar la presión. Delegar es la única vía frente a un ritmo de trabajo tan volátil como el de V\&S. Definir a todos como parte de una misma unidad es una estrategia de reforzamiento del trabajo en equipo. Llámese firma, empresa o familia; el objetivo es ser uno. Uniformes, congruentes, sincronizados. V\&S se apoya de la filosofía de la profesión hotelera, para capacitar al total de su fuerza laboral, a partir de la socialización y sensibilización diaria en el trabajo de servicio al huésped.

“...y ya les autorizaron a los de las oficinas empezar a bajar al comedor. Voy a tener lleno el changarro.” -“¿Ya están acá? ¿Cuándo se pasaron?” -“Esta semana. Yo creo que ya van a empezar lo del Club de Playa y prefieren amontonarlos allá arriba, pa' ahorrarse la renta en el pueblo." Para los operativos del hotel, los de arriba y los de las oficinas, son los colaboradores de las oficinas 
administrativas del desarrollo. Aún siendo los únicos que legalmente trabajan bajo la figura de V\&S, no son considerados parte del hotel. Fungen como una figura, similar a las oficinas de un corporativo, pero no tienen relación directa con los trabajadores del hotel. Todo es a través de CG y Asistente1. En gran parte, este divorcio se deba a que ellos no trabajan físicamente dentro del hotel. Pero en el momento en que se cambiaron a las instalaciones de V\&S, su convivencia con la parte operativa fue más frecuente. No así su integración. Sólo hay un empleado del hotel que tiene fuerte relación con los colaboradores de estas oficinas, y es el Contador del hotel. Si bien en cualquier tipo de empresa, la figura del Contador representa también una autoridad importante por el manejo del recurso financiero, en el caso de $\mathrm{V} \& \mathrm{~S}$, la toma de decisión de este recurso se encuentra depositada por completo en las oficinas de arriba, por lo tanto no se visualiza algún tipo de liderazgo o autoridad por parte de esta figura. Aún así, él y $\mathrm{RRHH}$ son el claro ejemplo de la formalidad con la que performan los trabajadores del hotel el personaje frente a sus superiores. Habitualmente, en la estructura orgánica de un hotel, las áreas de Recursos Humanos y Contabilidad, son departamentos que por la naturaleza de sus funciones distantes al huésped no son considerados propiamente de hotelería, pero por su cercanía con los altos mandos a partir de la relevancia de los recursos que manejan, son planteados en un nivel jerárquico superior al de División Cuartos, Sistemas, AyB, Seguridad, Mantenimiento y otros. De ahí, que la manera de dirigirse a ellos sea a partir de su título profesional. Es decir, Conta o Contador y Lic o Licenciada. 
Ningún otro integrante de V\&S, que no sea de los altos mandos, cuenta con la distinción de ser llamados de usted, como ellos.

La Licenciada $(\mathrm{RRHH})$ sí ha alcanzado un liderazgo carismático dentro del desarrollo, potencializado por dos puntos clave: 1) La empresa pagadora de nómina no se encuentra físicamente dentro del desarrollo, por lo cual la información no se maneja completa y adecuada para los trabajadores de las otras empresas -la contratación es una tarea adicional que se le da a las asistentes de las jefaturas de las otras empresas dentro del hotel-, y eso la posiciona como una fuente de primera mano sobre este tema; 2) Su toma de decisión frente al tema de la comida. Dando seguimiento al comedor y el menú que se les da a los trabajadores. Su gestión frente a CG en lo que a la prestación de alimentos refiere, así como su accesibilidad y atención a todo el personal (no tan sólo la operadora del hotel) la ha posicionado como una sexta figura clave dentro de la estructura orgánica de V\&S.

Esto nos lleva a una última figura clave: el dueño y gerente del restaurante (GR). GR administra los recursos que se utilizan dentro de éste, relacionándolo directamente con el comedor de empleados y su menú. El hecho de también ser autoridad en este tema, lo posiciona en un alto rango frente a la mayoría del personal. Tampoco se encuentra dentro del desarrollo de manera presencial, pero sus visitas son más frecuentes y su supervisión es más directa en comparación con el DG y DOH.

Entonces, para efectos de estudio del Hotel, la representación gráfica de autoridad quedaría como lo presenta el Gráfico 2. 


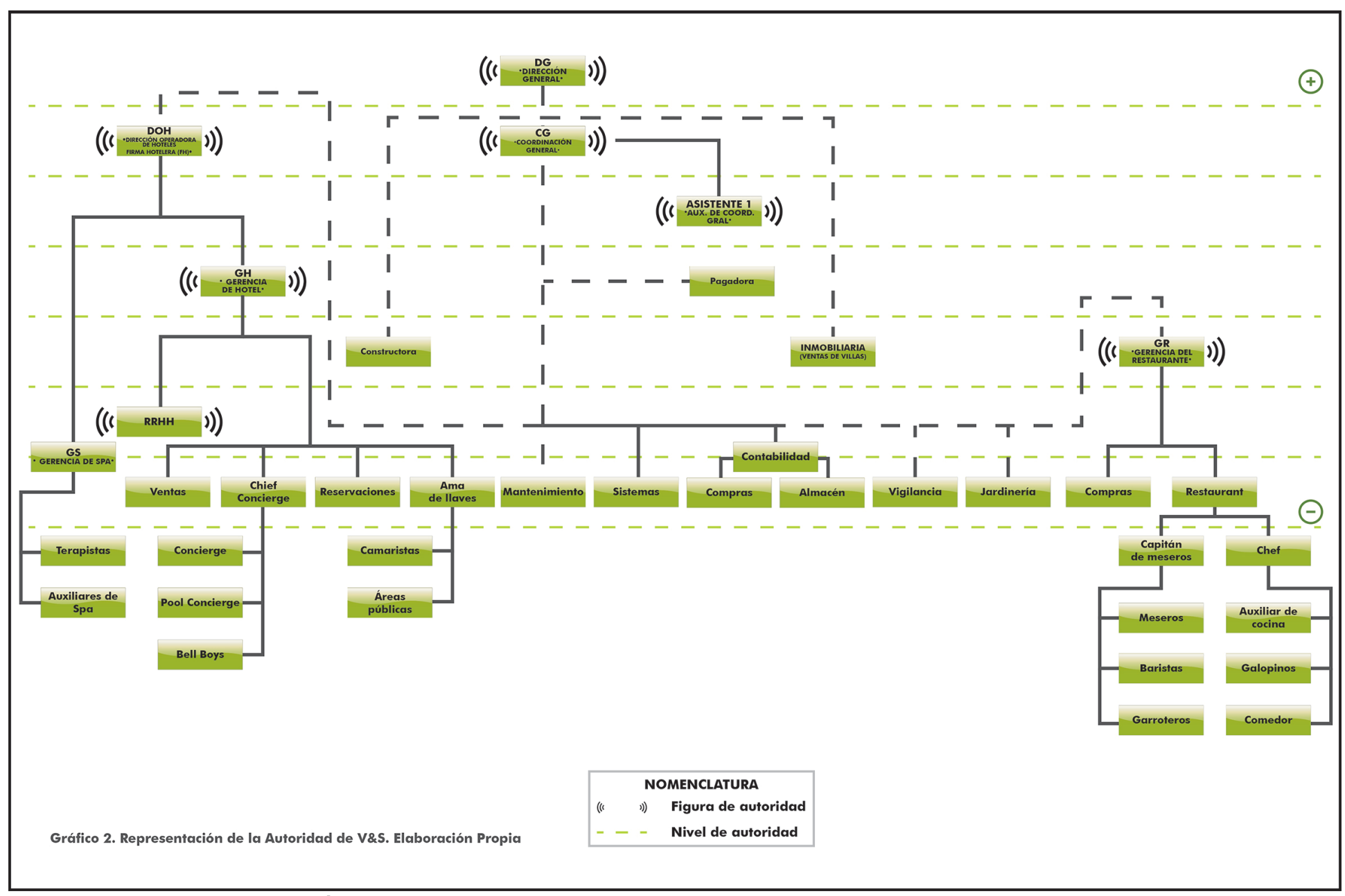

Fuente: Elaboración Propia

Los niveles de autoridad, en este gráfico, permiten visualizar como la opinión, gestión y decisiones de las figuras de autoridad, antes mencionadas, imperan en departamentos y otras figuras que se encuentran por arriba de ellos dentro de la representación formal de jerarquías. La lucha de poder entre estos personajes clave remite a "un juego de los candidatos estratégicos" (Mintzberg, 1992) donde ellos determinan en parte la configuración del hotel. 
Cocinero1 le sirve su postre a Trabajador3: “¿Estuvo bueno?” Trabajador3 aún tiene su último bocado y sólo responde haciendo una señal de aprobación con la mano: ¡OK! Cocinero1 la ha leído como delicioso. " $Q$ Qué bueno que les haya gustado!" voltea a ver a las camaristas en busca de su agradecimiento por la comida. Ellas levantan las cejas y aprietan los labios, mientras mueven la cabeza de arriba abajo. -“iBuenas Tardes, provechito!” Entra por la puerta Trabajador4. -“Gracias, gracias." Las camaristas al ver a Trabajador4, se percatan que ya se les pasó el tiempo y se apresuran a salir. "¿Sabes dónde se quedó Camaristo1?" -“Lo dejé terminando la villa de los VIP.” -“¡Bueno! Pues entonces, vamos ir a ayudarle. Nosotras ya terminamos las otras, allá te vemos. No se te olvide avisarle a Camarista5 que baje, cuando acabes." -“Va. No se me olvida." -“¡Permiso, Cocinero1!" Se azota la puerta del comedor.

Trabajador4 toma su charola y justo frente a la barra de comida, se queda esperando. No hace ni siquiera el intento de servirse. No tiene una actitud altanera como de quien exige ser atendido. Por el contrario Trabajador4 está cumpliendo una orden. Él no puede servirse. Sin mucha plática, hace de su conocimiento a Cocinero1 que ya está listo para comer: "Buenas Tardes Cocinero1". Cocinero1 es el encargado de cocinar para el comedor y servir a los compañeros. Aunque bajo la lógica de GR que la comida para empleados es un gasto, más que servir, Cocinero1 raciona la comida. A veces lo hace al pie de la letra, evitando desperdicios y dobles raciones. A veces lo hace al calor de su humor. Es decir, como se le de la gana. "¿Ya te anotaste en la lista compañero?, se dirige a Cocinero1 a Trabajador4 mientras le entrega la charola con los 
alimentos servidos. Se azota la puerta. Entra Trabajador1 seguido de Trabajador8. Trabajador3 hace un gesto de molestia y le baja al volumen de su radio. Mirando directamente a Trabajador8 le avisa: "Te anda buscando tu jefe." Trabajador8 se vuelve a verlo y piensa un poco: “¿Puedes decirle que estoy aquí en el comedor, porfa?" Trabajador3 no responde, toma su radio, da la ubicación y desconecta su chicharito para que se escuche la respuesta del Chief... Nada. Suena la extensión de la cocina.

"Se vale repetir postre, sobró mucha fruta del desayuno", Cocinero1 se dirige a Trabajador1 y a Trabajador3. Cocinero1 ha dedicado mucho empeño en el reconocimiento de su trabajo frente a los demás. Tanto que de vez en vez se permite ciertas atribuciones para beneficiar con mayores porciones a aquéllos que aún no le han dado un voto de confianza. "Nada más no digan nada, porque ya saben que me regañan."

Cocinero1 se dispone a salir del comedor. "Me avisan si llega alguien, no se olviden anotarse en la lista, porque luego viene la Lic y me la revisa a ver si se están apuntando". Fuera del comedor, Cocinero1 se lava fuertemente las manos, se seca con una toalla de papel que toma de un dispensador automático y en una seriedad fingida, como de quien no quiere parecer entusiasmado, se justifica. "Estamos revisando cuánta gente está viniendo a comer y cuánto se tardan, para pasarle un reporte a los directivos y justificar las porciones de comida que hago. La Licenciada me pidió mucha discreción. Por eso los ando arriando a que se anoten. Luego se les olvida y no vaya a ser que me reduzcan 
el pedido. (...)pues al final para los de cocina, toda porción representa dinero. No es fácil administrarlo."

La unidad de trabajo implica que todos se coordinen, que se sientan una sola familia. Sin embargo, los subgrupos son quienes dotan de mayor dinamismo a la organización. Estos resultan en el espacio en la naturaleza de las interacciones. De acuerdo a la audiencia que enfrentas, cierto personaje es performado. Este personaje tiene sus aliados definidos. Las agrupaciones convergen en intereses que los motivan a mantenerse unidos y tomar direcciones en común. Pero distintas a las de otros grupos. Para Cocinero1 es importante aliarse con los trabajadores de hotelería para sentirse parte de la organización. El hace uso del comedor como terreno neutral para los operativos, sin embargo, para él, el comedor es su territorio. Ahí el, supuestamente, designa la cantidad de las porciones. ambiente y el tono del trato entre los compañeros. Pero también, se agrupa con los mandos medios, para legitimar una posición jerárquica superior a la de la mayoría; a través de la administración de los recursos. Se considera parte de la toma de decisión en materia de comidas para empleados y le asegura una posición estratégica en caso de requerir alguna consideración. En ambos casos sus personajes son distintos. Aprovecha la información recabada de sus compañeros, de manera distinta. Se conduce paternalista, confiado, irreverente y extrovertido frente a sus compañeros de trabajo. Pero obediente, cauteloso, comprometido, abrumado de trabajo y un tanto caprichoso frente a RRHH. Con el huésped no tiene tanta experiencia, y al sacarlo de su territorio, se presenta serio, atento en demasía y sumiso. Estos personajes -"sí mismo" 
(Goffman, 1959:138)- que Cocinero1 busca, sus compañeros y demás audiencias, le atribuyan cuando está interactuando con ellos, "no deriva inherentemente de su poseedor sino de todo el escenario de su actividad, generado por ese atributo de los sucesos locales que los vuelve interpretables por los testigos." El espacio totaliza la legitimación de un personaje.

Es evidente que su prioridad está en el hotel, pero en dos espacios distintos a la mayoría. Ondulando entre su interés por formar parte de un grupo y obtener un estatus consolidándose en la estructura orgánica del hotel. Cocinero1 ve al trabajo como un medio para obtener beneficios personales (seguro social, identificación), laborales (consideraciones y posición estratégica) y sociales (recreación y ejercicio de un rol paternalista). Y su problema principal es quién le dará o no, crédito a su personaje (Goffman, 1959:138).

No todos son un mismo hotel, porque no todos lo viven de la misma forma. No todos interpretan la relación laboral bajo las mismas prioridades que Cocinero1. Por lo tanto, él busca afianzar un vínculo con la lógica hotelera, ya sea a partir de la operación o de las relaciones sociales. Todo depende de que escena haya montado de la mejor manera: ¿En qué espacio su performance es más creíble?, ¿para qué audiencia causó mayor efecto?, ¿dónde a generado un mayor vínculo? El vínculo forjado a partir del "efecto dramático" causado por Cocinero1 valida la atribución de su "sí mismo". A medida que el vínculo se fortalece, su realidad laboral cobra mayor sentido y legitima su razón de ser y estar en el hotel. En este caso, todo dirige a la satisfacción de un sentido de pertenencia. El 
vínculo habla de una reciprocidad. Ya no es sólo Cocinero1 buscando un vínculo, es también, el performance en la organización legitimando tal relación. Aspectos formales como la estructura, los lineamientos y los procesos dotan de sentido a lo vivido en los espacios; así mismo, aspectos informales como la relación con los sentidos, valores, apegos, sensaciones y afectos ahondan en el estilo de vinculación ceñido (3SBIZKAIA, 2012). Los trabajadores de V\&S reaccionan ante el performance en el hotel. Unos lo buscan (Cocinero1), otros lo rechazan (Trabajador7), otros lo afianzan (Camarista3), otros lo resignifican (Camarista1) y otros lo aprovechan $(\mathrm{RRHH})$. La reacción estriba del vínculo al espacio performado; un sentido territorial, de pertenencia.

\subsection{RELACIÓN CON LOS SENTIDOS, APEGOS, SENSACIONES Y AFECTOS}

RRHH sale de la oficina del GH. Con gran dominio histriónico se lleva el dedo izquierdo a la cara y lo posa justo debajo del labio inferior. “¿Qué me dijo que hiciera?, ¡ah, sí! Hago una llamada y ¿vamos a dar un recorrido?” Sin esperar alguna respuesta, entra a su oficina. No cierra la puerta. Justo enfrente Trabajadora5 teclea fuertemente en su computadora. “¿Qué hay en tu tiendita?” -“No he surtido, ¿tú crees?” Trabajador6 abre un cajón debajo de su escritorio. Para ellos dos, el área física de las oficinas, es un lugar cómodo. No implica ninguna formalidad más allá de terminar su trabajo a tiempo. La manera en que perciben la distribución de sus escritorios, les invita a imaginarse en una especie de cubículos -delimitación de un territorio-. El territorio está basado en la 
percepción humana. Se vincula con el sentido de pertenencia y la proxémica ${ }^{25}$. Como queriendo hacer una pequeña recepción, hay un medio muro que impide la conexión visual entre Trabajadora5 y Trabajador6. Aún así, no hay necesidad de alzar mucho la voz para que puedan escucharse. "¿Y eso?, ¡morirás de hambre!" -"Ya sé [lo dice en tono de queja]. Tengo medio paquete de galletas de la mañana y una paleta. ¿Qué prefieres?” Trbajadora6 no lo duda: “iLas galletas!” -“¡Por eso están gordos! Se la pasan comiendo. Mejor espérense a la comida. Ya falta nada." GH los interrumpe bruscamente con un tono fortísimo como si tuviera los oídos tapados y no pudiera escucharse así mismo. Pareciera que los regaña. GH no grita por prepotencia, tiene una manera muy directa para hablar, pero remata sus participaciones con un tono cínico que alude a su particular sentido del humor: “¿Qué hay hoy en el menú, Licenciada?” Esto último, lo ha dicho arrastrando las vocales. -"Ya les mandé el calendario a todos desde la mañana", contesta RRHH tapando el auricular de su teléfono. -“A mí no me ha llegado NA-DA. No mientas." -"Ni siquiera has revisado bien. Aquí tengo el correo abierto y sí estás adjuntado.” - ¡Ay, ya! Pues si tienes el mail ya abierto, de una vez dime qué hay, para ver si me quedo o me voy". Trabajadora5 sólo se ríe, ella se encuentra parada frente a Trabajador6 decidiendo que dulce tomar. -"Si te quedas las galletas, yo salgo primero a comer, porque muero de hambre”, la condiciona Trabajador6. -“Denme esas galletas, gordos”, grita GH saliendo inesperadamente de su oficina. Toma el paquete de galletas y regresa por donde vino mientras le da una mordida a una de éstas. "Lo que tengo que

\footnotetext{
${ }^{25}$ Proxémica es el término empleado por Hall (1972) para describir las distancias medibles entre las personas mientras interactúan.
} 
hacer por ustedes. ¿Saben cuánto me voy a tardar bajando esto en el gym?, váyanse a comer de una vez. Anden, yo aquí me quedo." -"Ahí viene el Chief", avisa Trabajador6 cuyo escritorio queda de frente a la puerta corrediza de la entrada. -“¡Pásamelo! De una vez me agarró con él”. De manera automática los cuatro guardan silencio. RRHH cierra la puerta de su oficina para seguir hablando por el teléfono, y el ritmo de las teclas de las computadoras de Trabajador6 y Trabajadora5 es hendido por la puerta corrediza. Entra Chief. Hablar de territorio es tratar la apropiación de determinado espacio que a su vez se conjuga con la sensación de amenaza - de pérdida o intromisión- por parte de otros actores. El espacio es performado de acuerdo al sentido de pertenencia. Al partir de organizaciones, los espacios son compartidos, pero no dejan de asumir una sensación personal de pertenencia. Las interacciones vividas en el espacio son trastocadas por esta sensación. De ahí, que el uso y la percepción que el ser humano hace de su área física, de su intimidad personal, y de cómo y con quién lo conlleva, también participen en la interpretación del espacio. Como lo propone la escala de las distancias interpersonales de Hall y sus modalidades (citado en Winkin,1984:93), la posición frente al otro incide en la percepción de la interacción misma.

En el momento que Chief es percibido, un personaje de Trabajador6 es performado. El área física es la misma, pero el espacio está cambiando. Trabajador6 adopta unas facciones serenas de total dominio muscular. Trabajador6 busca aparentar que no ha visto con anticipación al Chief, y suponiendo que Chief no lo ha observado desde antes, sus facciones deben 
presumir que Trabajador6 no está simulando y que el espacio performado al que se adentra Chief, es la normalidad de las oficinas. A partir de esa escenificación, Chief toma un referente y entra con mayor cautela de no interrumpir bruscamente las ocupaciones de los demás. “¿Está ocupado GH?”, pregunta en voz baja. "Sí, pero de hecho te estaba buscando. Así que, pásale." -“Vale, gracias". Los personajes son adoptados por los trabajadores de V\&S, para interactuar con otros. Lo cual indica que los roles son establecidos en parte, a partir de la audiencia a la que responden. Es decir, se adopta un personaje con base en la interacción con un público. Y así, como las interacciones de Trabajador6 pueden ser analizadas en conjunto a partir del concepto de programa (Scheflen en Winkin, 1984), para comprender la naturaleza de un grupo mayor. Su lógica puede ser clasificada de manera general a partir de los públicos que atiende.

El público es un concepto que se ha trabajado con anterioridad. Partiendo de las representaciones escénicas, un público son los espectadores. Goffman (1959) ha trabajado con el término de público bajo la la metáfora del teatro -una perspectiva de la actuación o la representación teatral-, para estudiar las interacciones entre los individuos: Trabajador6 hace uso de personajes para impactar en determinados públicos [compañeros de otros departamentos] y obtener una respuesta específica [sumisión]. 
La clasificación del público ${ }^{26}$ varía de acuerdo a los objetivos de los planes estratégicos. Pero a su vez, parte de una clasificación básica, dos grandes grupos de públicos: los internos y los externos (Fernández y Urdain, $2004^{27}$ ).

La participación de Chief en las oficinas administrativas y la operación del hotel es el punto de partida de su diferenciación, en parte por la capacidad de comprensión, acceso y uso de la información.

La participación dota de intereses de diversa naturaleza. No es lo mismo trabajar en un proyecto en común, que sólo vincularse con el resultado de esos esfuerzos. Podría pensarse que al ser parte del hotel, Chief deja de ser público. Pero de la misma forma que el público es un elemento inherente a la interacción (Goffman, 1959), los participantes del proyecto son un público -interno-, puesto que son observadores de las actividades que se hacen dentro de V\&S y su opinión repercute en la imagen y por lo tanto en la congruencia de sus propias actividades dentro de la entidad (Fernández y Urdain, 2004).

Un público interno conoce cosas distintas a un público externo, por lo cual la información utilizada para establecer un vínculo benéfico con el primero deberá hacer referencia a elementos más específicos e íntimos de la entidad que con el segundo.

\footnotetext{
${ }^{26}$ En el campo de la administración, las Relaciones Públicas (RRPP) es un área focalizada en el manejo de los públicos, por lo cual han profundizado en gran medida en el uso de este término. Principalmente ocupadas como estrategia para mejorar la imagen de una entidad: persona, grupo u organización, para las RRPP los públicos son todos esos grupos de interés que generan un juicio de la entidad. Son grupos de interés, puesto que tienen algún tipo de relación con la entidad -similar al concepto de "stakeholders" de Clarke \& Clegg (1998)-, y su opinión sobre ésta, puede afectar su imagen y por ende, su desenvolvimiento en el entorno que la rodea. La imagen de una entidad depende de la opinión de sus públicos. Parte de la importancia de las RRPP recae en encontrar un entendimiento referente a las metas de la entidad con los públicos, generando un clima óptimo para la entidad (Palencia, 2008).

${ }^{27}$ Basados en el grado de participación en las funciones operativas del hotel -muy similar a las dos modalidades de distancia de las relaciones interpersonales planteadas por Hall [cercana y lejana]-, un público externo [los proveedores, huéspedes y la competencia] tiene una relación menos directa, que el público interno [operadores, mandos medios, alta gerencia, socios]; es importante aclarar que dentro de esta clasificación actualmente existen otros autores que refieren a una tercera división: los públicos mixtos; donde se encuentran los públicos que no pueden ser clasificados estrictamente en alguno de los dos antes mencionados, por ejemplo trabajadores staff o accionistas.
} 
"De aquí mero, de San José del Valle. O sea que soy nativa de hueso colorado. (...) queda a pocos minutos entrando por Bucerías. No estás lejos." Antes de sentarse en su escritorio, Ama de Llaves tenía su bolsa, un par de lentes obscuros y un boing, sobre su escritorio. Los cuales guardó en su cajón personal, tan pronto tomo asiento. "La mayoría somos nativos, otros tantos de Vallarta y los menos de otros estados". Le mete llave al cajón. En V\&S, una parte importante de esos apegos que tienen los trabajadores con la empresa, es la sensación de estar en un proyecto cora. La Zona Metropolitana de Vallarta es así misma, la representación sintetizada del fenómeno cultural de identidad que ha venido forjando Nayarit desde tiempo atrás frente a Jalisco. Nayarit es uno de los estados más jóvenes de la República Mexicana y su territorio comprendía una parte del estado de Jalisco, que al integrarse al Pacto Federal en 1846, y debido al incremento poblacional dado en esa región fue denominada Territorio de Tepic. Su diferencia frente a Jalisco radicaba esencialmente en su población, la cual originalmente correspondía en gran medida al grupo étnico de Los Coras; lo que les hacía de una identidad específica que según los Coras "contrasta" con los jaliscienses. "No es lo mismo. Yo sí soy cora", explica Cocinero1. "Aquí la gente es de todos lados. El vecino es de Canadá, el otro de California. Muchos se vienen de Guadalajara, pero vienen de paso. Hacen dinero y se van. Nosotros no. Trabajamos por nuestra tierra. Es muy bella y es de las pocas regiones que aún mantiene su cultura. A pesar de tanto extranjero." De hecho el nombre Nayarit viene del idioma nayeri, lengua de los Coras. Por lo tanto, la sombra de Jalisco como un estado con ciudades urbanas, industriales y 
turísticas de gran importancia, ha motivado un fuerte empuje por parte de los nayaritas para distinguirse y destacar de su vecino del este. Sin embargo, su origen histórico y cultural siempre se verá ligado a Jalisco ${ }^{28}$. Bahía de Banderas se encuentra en contra extremo del municipio del Nayar (origen de los Coras y localizado al nororiente del estado), sin embargo sus habitantes se hacen llamar así mismos, y por tradición, "coras", para diferenciarse de los habitantes de Puerto Vallarta. Este municipio de Nayarit, es el más joven (fundado en 1989) y como hemos visto tiene su origen en el crecimiento dado por su cercanía a Puerto Vallarta. De tal forma, que si bien deben su pronunciamiento como municipio, al fuerte desarrollo impulsado por la inversión turística de la zona de Jalisco, con el paso del tiempo han buscado reforzar su identidad frente al ojo del turista a través de su propia marca cora: Riviera Nayarit ${ }^{29}$.

"De este lado se encuentra el hotel de mayor rango de la zona. Punta Mita es pura zona exclusiva, se mueve mucho dinero ahí y es lo que está llamando la atención actualmente. Hay más crecimiento hacia acá." Ama de Llaves no puede ocultar su gusto. La población cora vive orgullosa. Han aprendido a cacarear sus logros frente a los vallartenses. A tal grado, que la ciudadanía reconoce la importancia de la Riviera Nayarit, y las distintas empresas de servicios se alimentan de la población de ambos estados por igual. Esta sinergia no se logra a niveles gubernamentales intermedios (municipal y estatal); los recursos en conjunto no son bien administrados y existe poca alineación a planes conjuntos de promoción y desarrollo de la zona. Son más propensos a trabajar por

\footnotetext{
${ }^{28}$ Los Coras como etnia tienen una fuerte influencia de los Huicholes, ambos grupos étnicos se situaban originalmente en lo que hoy son las fronteras norte de Nayarit y Jalisco.

${ }^{29}$ La marca fue lanzada en el 2008 como parte de los proyectos de posicionamiento y promoción de sitios turísticos de México.
} 
separado, y desde la Influenza ${ }^{30}$, esa fórmula de trabajo ha decrecido la actividad económica.

"Antes había más trabajo. La gente pasaba de hotel en hotel, sin problema. Uno escogía, ahora ya no. De pronto, le tuvieron miedo a venir. Los hoteles bajaron su ocupación y resultó más difícil conservar un trabajo. (...)nosotros cambiamos. Le agarramos más cariño al hotel que nos contrata en temporada baja. Se buscó la forma de no afectar a tanta familia. Nos comprometimos más en salir adelante todos juntos. (...)se sentía una hermandad. La pasamos difícil.”

La marca Vallarta-Nayarit apoyada por Gobierno Federal representa esta necesaria fusión de esfuerzos, pero sobre todo en el caso de los nayaritas, el reconocimiento -posicionamiento- de su marca "Riviera Nayarit" y por ende, de un papel protagónico paralelo -equivalente- al de Puerto Vallarta, frente al extranjero.

Tanto Ama de Llaves como Cocinero1 dejan entrever una relación entre el compromiso con su pueblo y su trabajo. No existe razón para no vincular la bonanza en las empresas con la propia. Han sido testigos del efecto contrario en esa ecuación y les parece evidente, la importancia de su participación en el periodo de desarrollo y fortalecimiento de la región, como zona turística. Que Riviera Nayarit destaque de otros destinos turísticos, y la región crezca, no es papel del gobierno o la mercadotecnia, es el compromiso, que cada uno de los coras tiene, en atender al turista de tal forma que desee regresar.

\footnotetext{
${ }^{30}$ La Influenza AH1N1 afectó singularmente en el 2009 al estado de Jalisco, especialmente a Puerto Vallarta, disminuyendo la derrama económica del turismo y paralizando gran parte de los negocios de servicio. Jalisco, atacado por el estigma de la enfermedad, desarrollo actividades de promoción que desmitificaran la imagen de esa época; Nayarit por su parte, se dedicó a vigilar sus fronteras con Jalisco.
} 
"Nuestro turismo es distinto. No es lo mismo aquí que en Cancún, por ejemplo. Hemos aprendido a tratar a los canadienses y a los gringos. Sabemos diferenciarlos y adelantarnos a sus necesidades (...), antes de que cruce [un huésped] la puerta yo te puedo decir de dónde es y qué está buscando. ¡En serio! Todos sabemos hacerlo. Es nuestro trabajo: hacer que regresen." (Trabajador8, comunicación personal, 22 de mayo 2013).

Y entonces no tan sólo son de hotelería, sino que son coras. Aquí el público son los vallartences y los extranjeros. Trasladan esta naturaleza competitiva, de la sociedad a la organización $-y$ viceversa-. Se exigen con ferocidad grandes estándares, porque ya han aprendido de los errores del vecino, y no los piensan repetir. Existe una carga generacional de emociones que se depositan sobre los hombros de las nuevos coras especializados en turismo: orgullo, competitividad, patriotismo, compromiso, pasión, dependencia, entre otros.

"Es lo que nos gusta. Lo que sabemos hacer mejor(...), lo traemos en la sangre casi, casi." (Trabajadora2, comunicación personal, 29 de abril 2013).

Chief toma su trabajo de manera más práctica. Nacido en la ciudad de México, Chief pretende tener un crecimiento rápido en el hotel. V\&S representa un medio para sostener a una familia. "Tengo casi seis años acá, busqué la oportunidad. Sucedió que había que madurar rápido, hacerse cargo de compromisos personales, y así fue, ahora todo se trata de..." Minutos antes Chief supervisaba el avance de los preparativos para la llegada de los dueños. Deteniéndose en el Spa para confirmar horarios y logística de la presentación del área. Se topó a Trabajador1 saliendo de una puerta, con trapeador en mano. Un olor a eucalipto 
y especias de nombres largos y complejos se funden entre los suelos de madera y las sombras de los árboles. Chief aspira: “¿Pino?” -"Mas bien como cedro, ¿no?” -“Ni idea, pero huele un chingo.” -“¿Sabes dónde está GS?” -“Salió a Vallarta, acaban de llegar los últimos productos faltantes. Andaba muy nerviosa." -“Le marco entonces”.

Trabajador1 entra por otra puerta. Chief se queda pensando un momento en el barandal, en el interior del Spa, no hay aire acondicionado, sólo la recepción de éste se mantiene cerrada con clima, para fortuna de sus recepcionistas. Las demás instalaciones del Spa se esconden estratégicamente debajo de la copa de árboles frondosos. Pareciera encontrarse colgando entre sus ramas. Es fresco, no hay necesidad del clima. "Ni se escucha nada". El Spa como las villas, dan una sensación de vacío. Afuera la obra del hotel aún está en proceso, camiones de materiales se descargan en la periferia, ocultos tan sólo por una colina de arena. Pero adentro, las villas te transportan a lo profundo de una selva. La vista a ésta es desde las alturas, la playa remata el horizonte, y Chief, como los huéspedes, se da permiso de aislarse. Hay calma. Y en la calma, Chief pierde la vista y piensa "...las cuentas, la familia, los compromisos, los útiles, la renta. No me quejo, pero cada día hace falta más. Por eso hay que crecer. Para darnos mejores cosas, el tiempo corre...", coloca sus manos sobre la cintura y vuelve a aspirar. "¡Huele a paz!” Es verdad, se respira calma. Producto de los cursos de sensibilización, todos los trabajadores, especialmente mantenimiento y los de la constructora, se habituaron a bajar la voz al caminar entre las villas y cerca del Spa. Nada de escupir, nada de risas y nada de apodos. No se corre, 
“... hay que andarse rápido, atento pero sigiloso. Como que no quiere la cosa, te vas haciendo de mayores responsabilidades, para demostrar que sí puedes. El puesto se gana con pruebas tangibles. Poniendo al trabajo antes que a todo. $Y$ con una familia eso es difícil". Chief ha aprendido cuál es el performance para llegar a su meta. Observa cómo se desempeñan los demás mandos medios y busca superarlos. Identifica la vocación de unos como una priorización del trabajo y la ejercita con la visión de desempeñar este papel en su mejor versión, y prepararse para ascender. Los sueños, fantasías, miedos, vergüenza, ansiedad, se relacionan con actuaciones triunfales o descréditos, que lo inhiben a correr un riesgo, a mantener consideraciones con su equipo de trabajo, a segregarse o a apartarse (Goffman, 1959:138). "Estos atributos del individuo qua actuante no son un simple efecto descripto sobre la base de actuaciones determinadas; son de naturaleza psicobiológica, y no obstante parecen surgir de la interacción íntima con las contingencias de la puesta en escena de las actuaciones (Goffman, 1959:138)". La competencia no sólo se percibe en el los personajes adoptados por los trabajadores, se percibe en el ambiente, en el ritmo de trabajo. La piel también lo resiente. Entre más consideraciones obtienes o un mejor puesto, menor es tu exposición al sol. El desgaste físico está relacionado con la jerarquía. El aire acondicionado, la comodidad de una silla, el derecho a una oficina que te aparte momentáneamente de la operación, la posesión de un radio o línea telefónica personal para mayor practicidad de mantenerte en comunicación, todo está asignado a marcar una diferenciación, de unos sobre otros. Chief continua su revisión. Mientras camina, da 
instrucciones a diestra y siniestra a través de la radio. Cuando el trayecto es largo, toma un carrito de golf, y sigue por la radio. Conoce todas las cifras: cuántas habitaciones, cuántos huéspedes, cuántos baños, cuántos metros sobre el mar, qué temperaturas oscilan la temporada, cuántos días de lluvia, cuántos de sol, cuántos trabajadores, cuántas hectáreas de construcción, cuántos días de temporada alta, cuánta capacidad de las instalaciones, cuántos litros de agua se ocupan al día en promedio y cuántos días faltan para sus vacaciones.

Todos los datos sorprendentes para entretener al huésped, se los sabe. Sabe que en Vallarta no hay coladeras y que las piedras se encargan de absorber el agua sobrante. Sabe qué villas tienen mejor vista y cuáles son más cómodas si de familia se trata. Qué personas famosas se han hospedado y hasta qué pidieron de almorzar. Sabe las tallas de algunos huéspedes y seguramente sabe mucho sobre su intimidad. Pero, no es por un afecto a las cantidades y los datos engorrosos. Mas bien es por un gusto por hablar. El trabajador de V\&S es extrovertido por naturaleza, le gusta ser observado. Algunos buscan la atención frente al huésped, otros frente a los compañeros de trabajo y muchos otros sólo en la comodidad de las instalaciones de su departamento. Si el trabajador de hotel es quien atiende y no debe llamar mucho la atención, ¿por qué en su gran mayoría son extrovertidos? Chief no sólo gusta de atender al huésped, también disfruta de enterarse de las cosas, el mayor número de asuntos posibles, “...para mantenerme informado...", para mantenerse en medio de todo. Hay una necesidad social de resolver, atender, agradar, interactuar, de conocer gente. 
La relación existente con el tacto está ligada a lo afectivo, al compañerismo, a hacerse presente. El tacto es un medio para hacer sentir en confianza, al huésped, al compañero de trabajo, al amigo y al desconocido. El olfato está ligado a la sensación de comodidad. La vista está ligada a la atención, al detalle, a la precisión. El oído al sentido de alerta constante. Los sentidos están enfocados en mantener una escena de belleza y calma para el huésped, pero cuando estos fallan, está la boca. No es justificación, es distracción mientras la escena es resuelta.

Los sentidos prolongan el espacio (Hall, 1972) y se utilizan para dar congruencia al performance. Los sentidos perciben, absorben los datos y los ordenan bajo interpretaciones. El trabajador frente al huésped no debe demostrar esfuerzo. Entonces, cuando los olores de los químicos aturden a Trabajadora4, ella chifla quedamente para respirar por la boca. Cuando el huésped no gusta de que su espacio personal sea invadido, el trabajador endulza su tono y emana palabras que lo hagan sentir en confianza. Cuando algún detalle se ha pasado de largo, los trabajadores hacen uso de sus canales ocultos al huésped y se coordinan para resolverlo, o acentúan otros detalles positivos mientras se resuelve. Cuando no hay silencio, y debería, el trabajador simplemente se calla. Sin embargo, ante toda contrariedad, lo más importante es guardar la calma y sonreir. "Yo no sonrío por obligación, de verdad disfruto lo que hago, y motivo a mi equipo a que así mismo lo haga. El trabajo hay que disfrutarlo, dejarse ser".

Chief se encarga de resolver cualquier contrariedad en la experiencia del huésped. Por ello ha dedicado casi todo el día a determinar las condiciones en 
que se encuentra el hotel. El ascenso de Chief está en juego. Cualquier impresión o sensación de los dueños recae en cierta medida en su trabajo. Chief suprime todos sus sentimientos y los subordina al sentir del huésped. Existe una dependencia del otro.

Detrás del telón, donde se supone existe mayor libertad de ser, otros personajes son performados. En especial, al momento de interactuar con $\mathrm{GH}$. Chief no puede usar las palabras en este caso, todo es visto como justificación.

Chief tiene que aprender a regular sus expresiones. Si hay alguien que conoce mejor la operación y recursos con los que cuenta V\&S es GH. Cualquier dato puede ser usado en su contra. La mejor arma de Chief es el silencio y la confianza. La única manera de poner la balanza de su lado, es poder hacer creer al jefe, que tiene todo bajo control y que él puede resolverlo.

Para Chief no hay mejor expresión de aprecio que la confianza que pueda depositar GH en él. Confianza es información, información es capacidad de coordinación, coordinación es mando, mando es un mejor puesto y un mejor puesto se traduce en una mayor remuneración.

Chief abre la puerta corrediza, interrumpe a Trabajador6 con quien entabla pocas palabras y cruza la habitación. “¿Se puede?” Chief hace presencia en la oficina de GH con una singular alegría, como si supusiera que todo marcha bien y no hubiera razón de sentirse amenazado por una posible llamada de atención. Seguridad simulada en la que GH no repara. - ¿¿Cómo va todo?, ¿revisaste las villas?, dime que no hay novedades y que ya me puedo ir tranquilo de que todo 
está listo para recibir a nuestros huéspedes". -"Aún no terminan todas las villas, pero les falta muy poco. $\mathrm{Y}$ al parecer sí vamos a tener todos los productos del Spa para la inauguración. GS no me contesta, pero me dijeron que fue a Vallarta por los que no habían llegado". -"Bueno, bueno. Pero eso es Spa, y tu gente, está preparada. La chica nueva, ¿cómo va? ¿Ya puede quedarse sola atendiendo a los huéspedes?, ¿ya saben todos cómo hay que organizarlos en las villas?, no se me vayan a confundir de nuevo, y den unas villas por otras. Recuerda que tenemos amenidades específicas en cada una. ¡Por favor!”. GS intensifica la presión. La única forma de que las cosas salgan bien es a partir de la coordinación. Coordinar implica asumir un papel congruente con los esfuerzos de los demás. Sea el espacio que sea, la actuación de un trabajador acentúa ciertos asuntos y oculta otros (Goffman, 1959:37). En una interacción, $\mathrm{GH}$ asume el control regulando las percepciones de lo que se siente en el espacio. "Si consideramos la percepción como una forma de contacto y comunión, el control sobre lo que se percibe es control sobre el contacto que se hace, y la limitación y regulación de lo que se muestra es una limitación y regulación del contacto" (Goffman, 1959:37). Mientras Chief no logre regular las percepciones de su público, a partir de la información que brinda, no podrá "mantener un estado de mistificación en relación con el actuante" (Goffman, 1959:37). En relación con el público, el trabajador de V\&S debe ser capaz de administrar la percepción de los sentidos. Las sensaciones proporcionan información, por lo cual, todas deben ir canalizadas a promover y proteger el interés particular del espacio que estén performando. GH logra acceder y hacer 
uso de las sensaciones de Chief para potencializar cierta reacción y actitud en ambos. Si Chief no puede mantenerse firme, menos disperso y congruente, no será un ejemplo a seguir para su equipo de trabajo, puesto que no tendrá la validez necesaria para delegar, exigir y comprometerse. GH está probando la capacidad de Chief, para "mistificar" (Goffman, 1959:13). Su pase al ascenso, es convencerlo.

De manera más general, el espacio requiere de una alineación de las sensaciones emitidas, para ser creíble. Los personajes entonces deben sensibilizar sólo ciertas particularidades del espacio. Hablar de mistificación, no implica un engaño o falsedad, en este caso se trata de enfatizar y disimular determinadas sensaciones. La prudencia, como habilidad de administrar lo sensorial, es una estrategia más para ingresar a la élite de los trabajadores de hotelería. Retomando la personalidad extrovertida. GH tiene una personalidad dominante y que llama la atención. Frente al huésped, sin embargo logra mantenerse en control de la escena, pero pretende servir. GH guía a su público a través de preguntas y respuestas a un resultado presupuesto por él mismo. "Sí, ya tienen toda la información sobre las villas." -“¿Todos? ¿Lo confirmaste?, ¿les preguntaste claramente a cada uno de ellos, y supieron responderte o sólo les pasaste una hoja con información para que la leyeran? ¿Necesitas que lo revise yo?, ¿te hace falta algo?, ¿puedes con todo?, ¿me desentiendo?, ¿te hago un cheque con mi suledo?" GH sigue en un tono fuerte y cínico. Chief se ríe. -"Sí, está todo. Pero sigo pendiente por cualquier cosa que falte?" -“Pero no debe faltar nada. ¡Ya lo revisaste! ¡Uy!, ya me la estaba creyendo, yo creo que 
mejor sí me voy a ir a dar un rondín, por cualquier cosa." -"No, de verdad. Ya le di doble checada." -"Pues dale triple, no quiero sorpresas." -"Yo me encargo."

Dudoso, Chief sale de la oficina, toma su radio para localizar a Trabajador8 y regresa a la operación. "¡Comuníquenme con Mantenimiento! Que yo aún no tengo respaldo de todas las órdenes pendientes que me pasó Ama de Llaves. Y las fotos siguen llegando. No entiendo cómo dice Chief que ya está todo listo. ¿Por qué mienten gente, por qué? La mentira se les ve en la cara, ¡Dios mío!”

Ser parte de una élite, te permite obtener algo que los demás no tienen. Un espacio privado para ser tú. Los trabajadores de V\&S que demuestran tener la habilidad de mantener una postura, a partir de la regulación de las percepciones y sentimientos, obtienen mayor información de la operación. Mayor información implica saber más cosas que debes saber ocultar o enfatizar. La presión incrementa. El personaje se dificulta, y por ello, vas obteniendo consideraciones. El sentimiento de pertenencia incrementa de manera directa con la responsabilidad hacia el personaje. Mantener un equilibrio, requiere de ciertas condiciones para que suceda: una oficina para mayor privacidad, una radio para practicidad, aire acondicionado para relajar el ambiente y otras consideraciones que permiten la organización e interpretación de las diversas percepciones y que facilitan la performación de la multiplicidad de espacios en el hotel.

\subsection{RECONOCIMIENTO DE LA MULTIPLICIDAD DE ESPACIOS}

¿Cuántos espacios se performan en un hotel? El espacio tiene dos grandes temas para su clasificación y diferenciación: función y pertenencia (Winkin, 1984). La variedad de funciones y sensaciones de pertenencia ofrecen un 
panorama realmente amplio para la clasificación de los espacios. Sin embargo, ambas características se conectan en una misma diferenciación: el rol.

..."Buenos días, Señor. ¿Podemos entrar a hacer la limpieza o gusta que pase más tarde?" El huésped indica con los hombros que no hay ningún problema, yo he estado en silencio todo este tiempo, copiando la sonrisa de Trabajador4 y la mirada del huésped no se ha detenido en ninguno de los dos; Entra a la villa y comenta al aire que sólo iba por una toalla, la cual no le han ofrecido en el área de alberca.

-“¿Necesita sólo una?” Trabajador4 toma rápidamente la radio de su cintura y espera la respuesta del huésped. -“¡Tres!, si no es mucha molestia.”

-"Ninguna, permítame y se las hago llegar a la alberca".

Trabajador4 ha logrado que el huésped se detenga, observe la radio que tiene en la mano el camaristo y voltee a vernos detenidamente. Nosotros seguimos sonriendo. - ¿Qué amable!” Él regresa la sonrisa de manera medio agradecida y sale de la villa.

Mi silencio se me antoja incómodo y la sonrisa en mi cara un tanto tonta. Trabajador4, sin embargo, no parece exaltarse con los cambios de humor del huésped, quien ha pasado de una evidente molestia por la falta de atención del Pool Concierge (el responsable del área de albercas) a una desconfianza por el servicio, finalizando en una cara confusa entre tedio y satisfacción por haber conseguido lo que necesitaba aun teniendo que salir de la comodidad de su camastro.

Trabajador4 y el huésped han performado un nuevo espacio, sin eliminar el 
espacio en el que se encontraba Trabajador4 con anterioridad. El espacio está siendo performado por las relaciones y actos suscitados entre el Trabajador4 y el huésped. Todo tipo de actuar en una empresa, debe situarse dentro y entre la concepción de algún espacio.

La organización performa espacios (organizing <-> spacing). Por ello la importancia del análisis espacial dentro de una organización.

Tan pronto la puerta se ha cerrado, Trabajador4 lo ha pensado mejor y suelta la radio para discar tres dígitos en el teléfono: "Chief Concierge, que no hay nadie en el área de alberca, ¿y su Pool Concierge? Un huésped ya se molestó porque no hay toallas en el área. ¿Lo puede checar, por favor?"

Para los trabajadores V\&S no se mantiene estático. No significa que el hotel cambia drásticamente segundo a segundo, pero sí que existe una evolución, por pequeña que sea. A veces el cambio se encuentra en la manera continua en que lidian con los distintos públicos. Cada público es un tono distinto y una gesticulación acorde. $Y$ aunque las rutinas se presenten en la cotidianeidad de las labores, nunca será el mismo tiempo.

El tiempo transcurre continuamente, siempre hay un presente, un pasado y un futuro; y éste se percibe diferente conforme se enfrenta el trabajador a los distintos públicos.

En menos de cinco minutos, Trabajador4 ha viajado transversalmente por la temporalidad de distintos espacios. Mientras conversábamos hacia la villa Jade, el tiempo parecía llevar un ritmo despreocupado y muy íntimo. A su vez, Trabajador4 ya había observado la cercanía del huésped y esperaba hacer 
contacto visual para darle un giro de más calma y certidumbre al momento en que se dirigió a él. Enfrentar al huésped exigía una tensión en nuestras columnas vertebrales y los segundos pasaban lentos y cautelosos. No terminaba este escenario, cuando Trabajador4 ya estaba proyectando una urgencia en sus manos al tomar la radio. La eficacia es la primera regla, y los trabajadores del hotel lo saben; entre más rápido se atienda la necesidad de un huésped, menor es su molestia. La imagen de serenidad que proyecta un hotel depende de su urgencia en la atención.

Trabajador4 cuelga el teléfono, se ríe y me guiña el ojo, vuelve a tomar la radio: "Ama de llaves ¿me copia?, el huésped de la villa Jade me pidió tres toallas para alberca. Parece ser que se acabaron en el área y no hay nadie al pendiente, Gracias." -"Enterada" se alcanza a escuchar del otro de la radio -"Ya van en camino" responde una tercera voz y Trabajador4 culmina comentándome: "Así todos se enteran que alguien no está haciendo su chamba [se vuelve a reír]; ¡Chief Concierge!, eso es lo que quiero ser.”

Aún con todo lo acontecido, Trabajador4 no había dejado de pensar en la pregunta realizada antes de encontrarse con el huésped, sobre el puesto que le gustaría ocupar más adelante en el hotel. El enfrentamiento con el otro departamento y la confirmación de su jefe directo, le habían saciado su necesidad de reconocimiento y certeza de sus capacidades de operación (y dirección) en este ramo, a tal grado que no dudó en responder que él quería el 
puesto de su compañero de trabajo. En su cara se podía leer: ¡Yo lo haría mejor! Nuevamente el ambiente era de confidencia e intimidad.

"Un hombre tiene tantos yoes sociales cuantos grupos de personas cuya opinión le importa" (James,1890 citado en Winkin, 1984:100). Estos "yoes sociales" refieren a los personajes que son capaces de adoptar un trabajador de V\&S. A lo largo de los tres capítulos anteriores, los trabajadores de V\&S han desenvuelto sus interacciones en formas muy diversas. A su vez los personajes de cada trabajador varían. No son los mismos personajes performados por Cocinero1 que por Chief o Ama de Llaves, aún estando en un mismo nivel jerárquico. El personaje depende de los "grupos de personas cuya opinión le importa", o en términos de este trabajo: el público.

En el hotel, la multiplicidad de personajes permiten identificar los diferentes espacios vividos dentro de éste. Cada personaje, responde a intereses y prioridades particulares: una determinada lógica y dinámica. Por ejemplo, Camarista1 interactúa con Ama de Llaves en un personaje distinto al adoptado frente a Camarista3 que es su gran amiga y compañera de departamento o a Trabajador3 que pertenece a otro departamento, tampoco es el mismo personaje frente al huésped. En este sentido, el hotel representa para Camarista1, al menos cuatro tipos de públicos distintos que interactúan entre ellos; Cuatro espacios distintos.

De la misma forma, Trabajador4 mantiene una rutina establecida por los manuales de procedimientos aprendidos al pie de la letra, y la conjuga con un sentido de alerta a las necesidades de los huéspedes. Pero, como se ha 
presentado a lo largo del trabajo, la organización no sólo se vive como un espacio dedicado al servicio al cliente. Dentro de V\&S, se performan espacios dirigidos a otros públicos. Un trabajador puede desenvolver varios personajes, y cada rol difiere a un espacio de otro. Lo cual indica que los roles son establecidos en parte, a partir de la audiencia a la que responden. Es decir, se adopta un personaje con base en la interacción con un público.

Con dimensiones de formalidad e informalidad distintas. Tampoco son una contraposición entre el trabajo y el ocio, o entre la productividad y la improductividad; Dimensiones de todos estos elementos se encuentran presentes en los cuatro espacios, complementando el actuar de los trabajadores. Los cuatro personajes de la camarista son resultado y causa de un constructo dinámico de lo que se busca comunicar hacia fuera y lo que se expresa en la intimidad -un trayecto transversal entre los distintos niveles de distancia intrapersonal propuestos por Hall (1972)-. V\&S es performada a partir de una temporalidad multiespacial, que constituye complementariamente la realidad organizacional.

Si las interacciones que constituyen y refieren a un espacio son diferenciadas a partir del público que atienden en el área física es decir, en este caso, la organización; y la entidad es tomada en cuenta como los trabajadores dentro de una organización, podríamos decir que los trabajadores de las organizaciones trabajan de manera distinta con un público interno, externo y mixto, y en diferentes niveles -íntima, personal, social y pública ${ }^{31}$.

\footnotetext{
${ }^{31}$ De acuerdo a los niveles de distancia interpersonal propuestos por Hall (en Winkin,1984:93).
} 
Al ser grupos de interés para el trabajador, los trabajadores tienen una relación de participación diferente con cada público y cubren -así como satisfacendiferentes necesidades de éstos. Por ende la manera de presentarse frente a ellos difiere tanto en el manejo de la información, como en la representación de sí mismos y otros elementos que resultan en la conformación de un espacio performativo distinto, dependiendo del público al que se atiende. 


\section{CAPÍTULO 5}

Dinamismo:

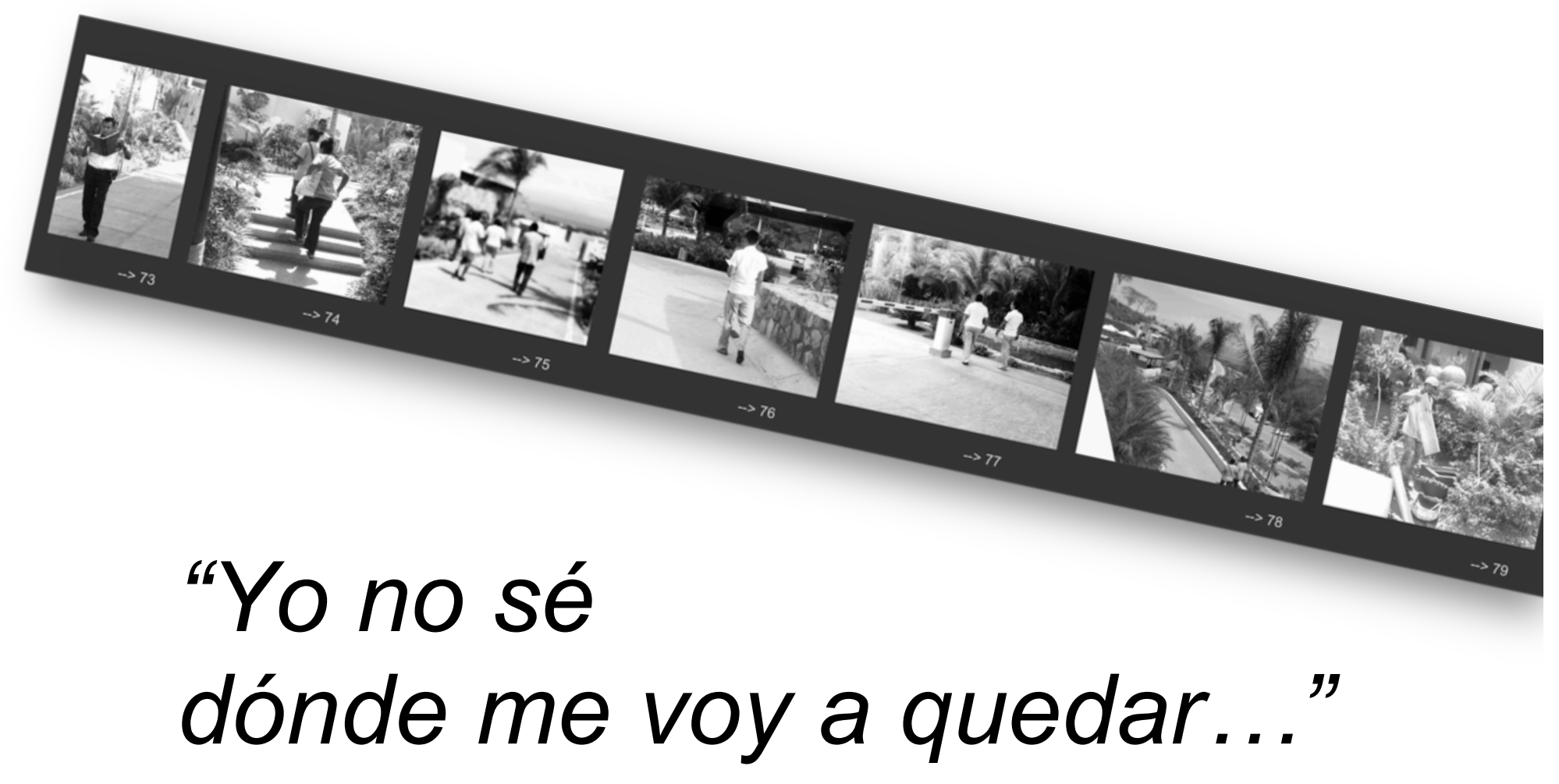




\section{CAPITULO 5. DINAMISMO.}

"Cada día a las nueve y media de la mañana se hace un briefing, el cual consiste en una reunión de treinta minutos en promedio para atender los puntos más relevantes del día y la agenda de los distintos departamentos" (Trabajadora2, comunicación personal, 29 de abril 2013).

Entra por la hendidura y cae al fondo con las otras monedas donadas. Su total es la magnitud característica de la ya famosa impuntualidad del mexicano. Chief Concierge paga sus diez pesos. La alcancía es sostenida por el propio GH. Con una sonrisa burlona y la ceja levantada. El brazo estirado de $\mathrm{GH}$ es imponente. "Ya sabes que no hay excusas. Creo que tú solito vas a pagar las pizzas". Chief no logra pronunciar una oración completa, la risa le gana y la pena frente a su jefe lo acobardan. “¿Ya están todos? ¿Quién va primero? A ver, Ama de Llaves, lee el Hoy Amanecimos, por favor." Apenada, voltea a ver a los demás, para saber si no sale alguien más en su ayuda para leer. Encuentra al responsable de Compras, con el que tiene una relación. Ni me mires, le dice él con los ojos y da unos pasos hacia atrás de manera juguetona, para perder el contacto visual con ella. Ama de Llaves, le reclama entrecerrando los ojos y presionando su lengua con la parte interna de su mejilla. Toma una hoja de su tabla de apoyo, la pone hasta el frente y la empieza a leer.

"La frase del día dice así..." No alza la mirada durante la lectura, sólo de vez en cuando busca la aprobación de GH. Terminando la frase motivacional referente a lo importante de una sonrisa en el rostro, Ama de Llaves enlista la temperatura promedio, ocupación del día, llegadas reservadas, el platillo especial del día, promociones, entre otros. De pronto, ella identifica un error en la lectura: "La villa 
muestra no es la 6-B, comenté ayer que se haría un cambio, y que esa la íbamos a usar para los huéspedes VIP que llegan esta semana." Todos voltean a ver a Chief. No hay preguntas, no hay dudas, cada quien sabe cuál es el umbral de sus responsabilidades. "iTarde y mal! A mí no me da risa Chief. ¿Cuántas veces pasamos por lo mismo? Tú gente no sabe. No preguntan. Hacen las cosas al aventón. Corrige esto, ipero ya! Y por favor, el que haga la guardia que verifique que todos sepan bien este dato. ¡No es posible, de verdad que no es posible!" Trabajador6 asienta con la cabeza.

El Hoy Amanecimos se distribuye a todas las áreas del hotel cuando inician sus actividades los turnos matutinos. El formato que resume el status diario del hotel es realizado en el departamento de Concierge, usualmente por el Auditor Nocturno, con base en la información recabada de todas las áreas. La claridad y veracidad de esos datos impactan en la coordinación de los esfuerzos de los trabajadores de V\&S. "Bonito se va a ver que los de ventas entren a enseñar una habitación a sus clientes y se topen con los chones de nuestros huéspedes. Y me voy sobre ti Chief. Un error y nos tiras todo el trabajo". En V\&S el equipo es la unión de fuerzas.

Cuando se habla de dinamismo, se está hablando de una noción de fuerza. A lo largo de este trabajo, se ha tratado con gran interés las interacciones dadas entre los trabajadores de V\&S. Su importancia recae, en que son éstas quienes dotan la fuerza que dan movimiento a los distintos espacios del hotel. Los 
trabajadores están inmersos en diversos espacios, de ellos dependen y sobre ellos influyen.

Los trabajadores, como los elementos destacados en la conceptualización del espacio performativo, interactúan entre sí; y a su vez, los espacios que éstos performan también interactúan unos con otros.

En el espacio performativo, se incluye el dinamismo entre sus categorías esenciales, puesto que es la base para comprender que en la relación espaciotrabajador, uno no existe sin el otro. En sus distintos niveles, V\&S como un espacio performativo, es origen y resultado de las múltiples interacciones convenidas en éste.

De la misma forma, la fuerza implica una intención. Las interacciones trazan trayectos de la dinámica de V\&S; se performa en una dirección. $\mathrm{Y}$ al no ser concebida sólo como una magnitud vectorial, la fuerza implícita en el dinamismo, también tiene como efecto transformar a la entidad. Es decir, las interacciones no sólo dirigen, también acotan la realidad que se vive en V\&S, todo depende del momento dado.

Por eso, a lo largo de este último capítulo se enfatizará en el personaje del narrador, como una parte misma de las interacciones con los trabajadores, y la incidencia en las reacciones de ellos. Es dentro de esta categoría donde se explicita la importancia del conjunto; un todo a partir de sus partículas. Y la inserción al estudio de caso, en su etapa inicial, tuvo un proceso de interés para el trabajo, que permite abundar en la fuerza de las interacciones con los distintos personajes del trabajador de V\&S. 


\subsection{DIRECCIÓN, TRAYECTORIA}

En el briefing se reúnen los representantes de cada empresa, es decir las jefaturas de los departamentos, y detallan la situación real de sus departamentos, proyectos en proceso y diligencias del día. Anand y Daft (2007:336-338) hacen referencia a este tipo de coordinación como mecanismo utilizado por las nuevas formas de organización. Para los autores, este tipo de diseño nuevo, es una tendencia de las organizaciones que hacen frente al ambiente competitivo en un contexto dominado por las tecnologías de información y donde los esfuerzos se dirigen no tan sólo al trabajo en equipo, sino especializado y sobre todo a través de relaciones con otras organizaciones.

Siguiendo la línea de los autores, VS se presenta como lo que Anand y Daft (2007:336) Ilaman una Organización Modular, al no hacer uso del outsourcing como "una pieza del producto sino como proceso organizacional". Ése es el caso del departamento de mantenimiento, vigilancia, alimentos y bebidas, y ventas. La misma pagadora de nómina deja de atender sólo una parte del proceso, para manejar las actividades derivadas de la administración de nómina del recurso humano de VS. Finalmente, sucede lo que GH mencionaba, cada departamento representa a "una firma" distinta, pero frente al usuario son una misma empresa.

Esta necesidad de ser una sola en apariencia, requisita un ensanchamiento del aparato administrativo que defina a través de estas juntas de control (el briefing), los lineamientos y procedimientos a seguir y evaluar en la empresa. El flujo de información y la participación en la toma de decisión de los acuerdos por parte 
de los representantes de las distintas empresas, se convierten en ejercicios estratégicos para el control y coordinación del trabajo en equipo.

Con esto se puede concluir, que es una organización acostumbrada a trabajar bajo proyectos, que a primera vista pareciera mantener una centralización de la autoridad muy fuerte. De ahí que se reconozca la parte empresarial (Mintzberg, 1992) a partir de la centralización de la toma de decisión en DG; Sin embargo, al enfocarse esta primera etapa de V\&S en el desarrollo del área hotelera, la profesionalización es un punto importante. Actualmente en la toma de decisión impera la lógica aprendida en la hotelería. Se ha mencionado que el proyecto de V\&S, de origen, buscaba ofrecer un espacio residencial con comodidades de lujo para sus inversionistas, ampliándose hacia los servicios hoteleros para incrementar el flujo de dinero, que había sido frenado por contingencias de la zona turística. La lógica del negocio hotelero, sus procedimientos, sentido hacia el cliente, estructura, práctica y teoría básica, han permeado la totalidad organizacional del proyecto. Aún en una etapa inicial, la estrategia, o más bien el eje preponderante en el hotel varía provocando etapas diferentes en la vida de la empresa: hay momentos de creación e innovación y hay momentos de resolución de detalles y facilitador de recursos; hay momentos de expansión y trabajo acelerado, hay momentos de supervisión y trabajo rutinario. Lo interesante es que todos esos momentos se pueden situar de manera paralela, al mismo tiempo, dentro de V\&S. 
La "cultura hotelera" fuertemente arraigada en una zona turística como lo es Vallarta-Nayarit, determina las directrices específicamente en lo que se refiere a procedimientos, atención y logística de VS. El briefing permite ejemplificar esta influencia. GH es quien modera la junta, a él se le reporta. Las demás firmas se sitúan por debajo de él, al menos en estos treinta minutos.

"A mí me ayuda mucho [el briefing] por eso. Es importante estar para saber qué o cuáles son las cosas importantes del día: quiénes llegan, quiénes salen y qué problemas surgieron el día anterior. Ya para ese entonces, yo tengo listos bien mis reportes con sus respaldos, por si sale alguna pregunta. Las dudas se aclaran en ese momento. Todos le chambeamos duro, y si algo sale mal en la junta siempre sale a relucir. Y pues ni modo, al que le tocó, le tocó. [se ríe] Todos somos responsables de la estancia de los huéspedes. Son como el cliente, ¿no?(...) Cada quien en su depa sabe qué y cómo hacerlo. Por eso somos encargados. No se vale el yo no sabía, para eso está el briefing(...)" (Constructora, comunicación personal, 18 de junio 2013).

La misma constructora del desarrollo se ha adaptado a las necesidades de la logística hotelera, dando por ende, una posición estratégica a $\mathrm{GH}$, en el que como ya se había mencionado, se delega una fuerte capacidad de toma de decisión. Existe una confianza en su figura, no tan sólo por su experiencia, sino por la falta de conocimiento de DG y CG, en el giro hotelero.

Respaldando a $\mathrm{GH}$, Todas las jefaturas departamentales dentro del área de AyB y el Hotel cuentan con licenciatura en turismo (ya sea especializadas en gastronomía u hotelería), reforzando la replica de esta lógica que se menciona y 
sobre todo de una filosofía (y vocación) de atención y servicio al cliente, imperante y necesaria en este ramo.

Por ello, la experiencia del huésped es el resultado a evaluar. La elección y administración de los recursos quedan a la discrecionalidad de las jefaturas de los departamentos, respaldada en esta selección de personal profesionalizado y teóricamente capaz (porque así ha sido instruido previamente en sus correspondientes instituciones educativas) de trabajar en equipo. La información manejada al interior de V\&S y los procesos de comunicación, promueven un sentimiento de participación que se lleva realmente a la práctica. Aquéllos que los desconocen o que no están acostumbrados, tienden a adaptarse.

En el briefing no participan las oficinas administrativas del corporativo a las que todos ellos reportan, ni la empresa de ventas encargada de promover los fractionals. Así, los departamentos que sí asisten y normalmente no forman parte de los de hotelería, durante la junta se unifican y son tomados en cuenta de manera paralela en la operación. La razón principal es esta subordinación de su tiempo operacional al del hotel, evidenciado en la asistencia al briefing y de sus procedimientos, como el uso de reportes y respaldos. Tan sólo el hecho de llamar a la junta matutina diaria briefing, ya declara una inclinación hacia la lógica hotelera.

"Esta semana tenemos la visita de DG y además se incorpora temporalmente, un nuevo integrante a nuestro equipo, que posiblemente ya han visto deambular por el hotel..." GH hace una pequeña introducción e invita a presentar la razón de mi asistencia en el briefing. Después de exponer a grandes rasgos mi 
curriculum vitae, $\mathrm{GH}$ solicita una apertura y apoyo para involucrarme en las distintas áreas de la operación. Las miradas son pesadas, hay extrañeza y falta de información para acreditarme como uno de ellos. Aún así, se presentan y saludan con cordialidad. Acto seguido, una lluvia de comentarios sobre la operación de los próximos días.

-“No sé cómo reciben facturas así..." -“Los de ventas son bien gritones, fumadores y molestan; no entienden..." -"Pues no son hoteleros, y si no ven lo que van a comprar, no lo compran y ya..." -"Comentar no es lo mismo que una requi, Lic. y me siguen mandando todo mal..." -"Ya no tengo recursos. Ya les dije que no les garantizo nada..." -"Nos invadieron, y ese espacio ni siquiera es de nosotros, es para el huésped..." -"Los de arriba dicen que tienen un horario fijo y no pueden bajar a comer a esa hora..."

Los puntos seguían saliendo, cada queja era comentada brevemente. En la aceleración de las propuestas de solución y comentarios al margen, $\mathrm{GH}$ iba cayendo en cuenta: "Bueno, pues es que entonces no somos nosotros, json ellos!" La conclusión caía como voto de confianza en el trabajo de cada uno de los encargados de departamento. "Pero, no le voy a poder decir eso a DG, ¿verdad? Entonces, ¡resuélvanlo! Esto es cosa de todos. Sino todos nos quedamos sin chamba. Que tengan un excelente día. Ciao, ciao. ¡A trabajar, bye!"

$\mathrm{GH}$ no es un gran moderador, pero no hay quien lo tome personal. Todos parecen estar de acuerdo. Similar a una fila india, van saliendo de la oficina de $\mathrm{GH}$ acordando detalles y el seguimiento a las tareas pendientes. 


\subsection{MOVIMIENTO, INTERACCIONES}

"Yo estoy desde que se abrió. ¡Uy!, ya no somos lo mismo. Empezamos en un cuartito, ahí guardábamos todo. Luego dividíamos cosas ahí y en la oficina de la Ama de Llaves. Pero pues no se podía mucho, porque estaba Almacén y se juntaban las cosas. Se ocupó una villa. Pero un día tuvimos lleno y se tuvo que sacar todo y cambiarse a otra villa que aún no se terminaba y pues no estaba en renta. La verdad es que yo no sé dónde me voy a quedar. Esto está creciendo y hay oportunidades. Ya se van a abrir más habitaciones allá arriba. Pero si mañana se llena el hotel de nuevo, vamos a tener que sacar otra vez todo [se ríe], ¿a ver a dónde? Les invadimos las oficinas para que vean que ya urge [el área de ropería]. Mientras el huésped no note el desorden, no hay problema. Eso nos toca a nosotros. (...) ¡Queremos que crezca!" (Trabajador4, comunicación personal, 07 de junio 2013).

Trabajador4 mantiene una relación muy fuerte entre el área física de trabajo y su desarrollo profesional. Que el proyecto de VS esté aún en construcción, no le implica una sensación de desventaja, por el contrario, pareciera ser siempre una oportunidad de mejora. Mucho influye que, durante la temporada que llevan abiertos, la constructora no ha dejado de entregarles áreas, por ende, los trabajadores han visto de primera mano, el crecimiento que está teniendo el hotel. Todos saben que apenas va la primera de muchas etapas del desarrollo. Aún así no lo ven como un futuro lejano o medio, tal cual está proyectado. El espacio es performado: el trabajador vincula el trayecto (temporalidad) de un área física con su desempeño (performance), y éste se relaciona con la expectativa de progreso en diversas esferas de su actuar (interpretación de la 
realidad). El área física es interpretada por Trabajador4, desembocando en un rol particular dentro de ésta (Hall,1972).

Para Trabajador4 el crecimiento es constante y eso le da una seguridad que forma parte de una empresa grande. La percepción de una empresa grande en la zona de Riviera Nayarit involucra hoteles de 3 ó 4 diamantes, campos de golf, casinos, cientos de habitaciones, entre otros. No es un sueño inalcanzable, así son un gran número de desarrollos hoteleros y residenciales en la zona, los cuales empezaron poco a poco. Existe una confianza en estos proyectos y la inversión constante que está teniendo VS es perceptible, lo cual ofrece certidumbre traducida en fidelidad al proyecto. Por lo tanto, ni Trabajador4, ni las camaristas, ni Ama de Llaves demandan un área física fija en este momento, por el contrario, ello supondría que la inversión está congelada por determinado tiempo. Si bien frente a los compañeros de trabajo la situación de las áreas es expuesta en forma de quejas, mencionadas con un tono de vanagloria cuyo objetivo es enfatizar que aún bajo esas condiciones, el trabajo está saliendo: otra marca de guerra.

En este momento sería considerable mencionar que esta actitud de crecimiento también se apoya en su "orgullo cora". Los nayaritas de esta zona mantienen esta constante comparación con su vecino jalisciense: Puerto Vallarta les ha abierto y enseñado la manera de obtener un futuro a través del servicio al turismo. Nuevo Vallarta fue el ejemplo que en Nayarit también era factible. Así siguieron las demás localidades que se extienden a través de la Bahía de Banderas. Para los coras, la capacidad de hacer las cosas igual o mejor que en 
Puerto Vallarta, ya no es un reto, es una forma de vida. Eso les ha permitido hacerse de una identidad independiente a Vallarta, aunque aún dependan de ella. Su intención es que la dependencia se transforme en una codependencia. Si a ello le añadimos la formación hotelera, donde el trabajo de tiempo completo es una vocación: "No cualquiera puede hacerlo, sólo quien sabe lo que es la hotelería", el resultado es un personal de trabajo comprometido, apasionado y que prioriza la atención al huésped, por sí solos.

Al salir de la junta, todos toman un rumbo distante, algunos se suben en un carrito de golf para bajar a las tráileres del estacionamiento, otros caminan un piso abajo cerca del Spa, y otros se despliegan por la parte alta del hotel. Es temprano, los huéspedes desayunan y otra gran mayoría descansa aún en las villas. Al ver el movimiento de encargados de departamentos, aquellos trabajadores que se encuentran en las áreas públicas aprovechan para resolver dudas suscitadas durante el tiempo que duro el briefing. Ama de Llaves está revisando avances con Trabajador4. Trabajador3 los cruza. Sube por la alberca, llega al restaurante, y ve bajar a un huésped al que saluda con cordialidad. Dirigiéndose a su oficina en el edificio de la colina, junto a la oficina de CG. Sube unas escaleras y cruza una glorieta que lo lleva por el sendero principal donde se despliegan las primeras villas. En la parte alta remata el edificio nuevo y a su costado una malla verde que cubre el área de construcción de la segunda etapa del desarrollo. A escasos metros de esa malla, un guardia de seguridad (Seguridad2) se cubre del sol colocando la bitácora de pasta dura sobre su cabeza y lo saluda. La pequeña casita que figuran las hojas abiertas de la 
bitácora, ofrecen una sombra que se antoja envidiable. Trabajador3 se vuelve a verlo, y Seguridad2 ya se ha quitado la bitácora de la cabeza, lo saluda levantando un poco la quijada y mantiene posición de firmes sobre el cemento. Es amable, pero serio. Trabajador4 entra al edificio y Seguridad2 se vuelve a tapar con la bitácora. Subiendo por el mismo camino, Ama de Llaves se ha topado con Camarista3 y yo visualizo a Seguridad2 con la bitácora descansando en su cabeza. Justo al momento de querer tomar una foto que deje prueba de lo observado, retira la bitácora de su cabeza y me saluda. "Buenas Tardes, ¿cuál me dijo que era su nombre?" Ama de Llaves responde a su pregunta y me presenta, en seguida anota la hora en que nos encontramos. Es pulcro y de caligrafía legible. "No es desconfianza, sólo que aquí guardo dato y seña de todo lo que veo. Es como un parte de novedades, pero aquí le llaman bitácora. Se oye menos militar, ¿no? Me informaron que puede tomar todas las fotos que necesite, sólo no me tome así, porque me regañan. Mejor dígame dónde me pongo." Agradezco su apoyo, finjo tomar una foto de él con la zona en construcción de fondo y sigo mi paso. Pasos más adelante, Ama de Llaves dobla en una villa y me detengo detrás de unas hojas grandes de palma tipo botella. Seguridad2 vuelve a tomar nota de lo que supongo es el número de villa al que cree que hemos entrado y posa la bitácora de nuevo sobre su cabeza. Intento una nueva foto, pero alguien más que yo no logro ver, le ha dado aviso. Baja la bitácora y ríe. Segundo intento de foto: frustrado.

¿Es tan malo dejar evidencia de la manera en que sobrellevan las contrariedades de su trabajo? Seguridad2 lleva un uniforme completamente 
negro, sin algo para cubrirse del sol, y a excepción de los momentos que se da para tomar un poco de agua, los rayos le darán directamente al menos hasta el mediodía. Su piel es dura y de un moreno más obscuro y seco. Parece un rostro de piedra si no es por la sonrisa dibujada con la que se maneja frente a los demás. La diferencia entre Seguridad1 y Seguridad2 es el perímetro de su vigilancia. Uno es interno y el otro externo. Uno interactúa en mayor medida con la operación del hotel, el otro se limita a dar acceso a los transeúntes. Un joven niño se acerca a él, le solicita información sobre el horario del desayuno. Seguridad2 toma su radio, pero no lo ha utilizado para preguntar la duda a Concierge, por el contrario ya la ha resuelto (los horarios vienen en el Hoy Amanecimos) y ha llamado a Bell-boy para que lleve al niño y sus padres al restaurante.

"Yo trabajaba antes en un condominio. Era el de accesos, tenía consultorios, oficinas de despacho y arriba eran departamentos de uso habitacional. Me iba bien, porque era muy relajado, pedir identificación, ofrecer un gaffette y avisar a las distintas extensiones. Pero pues no se paga tanto(...) Trabajaba $24 \times 24$ pero ni descansas bien. Lo que me gustaba era tratar con la gente, platicar mientras esperaban y recibir a todos. Vas conociendo a la gente, y te vas ganando su confianza. Hasta me hicieron un pastel cuando me fui. Después de un tiempo te cambian el servicio. Y me tocó aquí. Ahora son tres horarios distintos y te dan un día de descanso. (...)me subieron el sueldo, porque ya no trabajo para esa empresa directamente, me pagan los mismos, pero ya soy parte de los del hotel. Creo que les gusta mi forma de trabajar. No es fácil tratar a la gente y no a todos les gusta. Te obliga a procurar tu aspecto, porque todo el mundo te está viendo 
¡Ahora imagínate verte bien fresco con este calorsote!” (Seguridad2, comunicación personal, 22 de mayo 2013).

No me lo imagino, lo veo. Seguridad2 tiene el cabello relamido hacia atrás, con un pequeño fleco de lado tan duro como su piel. El sudor se percibe apenas en el brillo de sus ojeras, pero no así en gotas sobre el cuello, o la frente. Huele a colonia y su dentadura se ve cuidada. El uniforme no le queda holgado y aunque descolorido por el sol, mas que por el uso, tiene la línea del pantalón bien planchada. "Es algodón, entonces no me acaloro tanto. Ya nos van a mandar a hacer unas gorritas, yo les dije que hacían falta. $Y$ no se ven mal con el uniforme. Nos vamos a ver como guardias de la costera." La diferencia de interacción entre Seguridad1 en la caseta principal y Seguridad2 al interior de la operación, supone una diferenciación sobre la interpretación de su trabajo, pero sobre todo, de su presencia. En Seguridad2 hay una consciencia mayor sobre la observación de otros hacia él. Hay una consciencia de los públicos a atender.

En este caso el público son las personas que observan a Seguridad2. Sin embargo, en una interacción, los trabajadores son personajes y a su vez, públicos de otros personajes (Goffman, 1959). Seguridad2 no sólo observa a Trabajador4 cuando pasa frente a él, sino que adopta un personaje firme para que Trabajador4 responda de manera accesible pero respetuosa al saludo. Así mismo, Seguridad2 me identifica y pretende adivinar mis propósitos al merodear la zona. Sin embargo también se sabe observado. Su personaje debe proyectar objetividad, atención al detalle y rectitud. El es personaje, y público de los personajes que otros públicos adoptan frente a su personaje. Su personaje es público de otros personajes (Goffman, 1959). 
De acuerdo a la clasificación básica de públicos retomada por Fernández y Urdain, 2004, la organización tendría un programa (Scheflen en Winkin, 1984) distinto para cada público; es decir, Seguridad2, como los demás trabajadores, incorporarían al menos tres tipos de lógicas básicas en su actividad diaria: la lógica interna, la mixta y la externa.

V\&S, vista como un Spacing Organization, estaría fundamentalmente performada por el espacio interno -colaboradores del mismo departamento-, externo -huésped- y mixto -otros compañeros de trabajo, mandos medios y alta gerencia- de los trabajadores. Sin embargo, es importante recalcar que esta clasificación básica sólo es una manera didáctica de hacer hincapié en la multiplicidad de espacios formadores y formados con base en las interacciones de los trabajadores con sus públicos y como público de éstos.

La lente de análisis que ofrece el Spacing Organization, de acuerdo con Beyes y Steyaert (2011), remitiría a analizar no tan sólo las interacciones de los trabajadores, sino a construir un mapa de interacciones más amplio de los eventos que conforman el espacio performativo organizacional (Czarniawska, 2004), a partir de la participación de actores esporádicos y los detalles más pequeños -sonidos, colores, energía y materiales-.

Aún así, para efectos de este trabajo, el espacio performativo organizacional es una oportunidad -o excusa- de tratar el rol del trabajador desde otra perspectiva, un perspectiva más real, más apegada al campo que a la teoría. No se busca una perspectiva más humana en el sentido de crítica al rol de productividad que 
transgrede las necesidades básicas del trabajador como individuo; sino orgánica, referente al ritmo en que se presentan los eventos en la vida del trabajador.

\subsection{ACOTANDO LA REALIDAD}

La multiplicidad es un elemento crucial en la concepción del espacio performativo, pues permite imaginarse la diversidad de roles dentro de V\&S por parte de un mismo integrante del hotel.

De acuerdo a lo que se percibe es que los trabajadores se desenvuelven. Cada espacio significa una particular disponibilidad de actuar. En principio, la importancia del espacio dentro de la dinámica del ser humano parte de que el comportamiento en un espacio, representa la relación existente con éste (Hall, 1972). Aún más, el comportamiento del trabajador es continuo formador del mismo espacio. En parte, una cuestión sumamente particular ya que depende de lo que cada individuo percibe con sus sentidos de su posición dentro de un espacio, pero por otra parte, una construcción colectiva puesto que las lógica son socializadas y compartidas dentro de la organización, con el fin de agruparse (organizarse). Por ejemplo, en un hotel hay una serie de áreas físicas muy diferentes: habitaciones, lobby, restaurante, piscina, recepción, bar, salones de eventos, salas de juntas, oficinas de ventas, oficinas de dirección, almacén, área de ama de llaves, ropería, pasillos, escaleras, sanitarios, entre otros. Todos estas áreas mantienen una premisa en general: el servicio al cliente. Los trabajadores que se encuentran participes dentro de estas áreas, conjugan con esta premisa, haciendo de sus actos una dinámica afable para los clientes. 
Todos perciben a V\&S como un espacio destinado al huésped.

Czarniawska (2004) hace hincapié que son los actos quienes integran la realidad organizacional. De manera continua y a través de lo performativo -la incorporación diaria de los trabajadores-, el hotel se ha ido construyendo, en parte, en un espacio organizacional destinado a la atención de los huéspedes.

La interacción de las personas es la vía para observar las lógicas distintas de actuar y por ende, los espacios que conforman a una organización. Por lo tanto, el hotel visto como un espacio destinado al huésped es sólo una de las tantas lógicas que participan en la incorporación de diversos espacios que, a su vez, interactúan y se traducen en la propia organización.

Después de aquella foto fallida, viajo con el celular en la mano -con éste grababa las conversaciones y tomaba las fotos-. Era claro que para desenmascarar los personajes se debía estar al pie de cañón. Sólo hay una oportunidad para obtener esos chispazos ajenos al personaje frente al huésped. Evidenciar las incongruencias del personaje, desmantelan la escena y dejan entrever tras del telón (Goffman, 1959). Sólo había una oportunidad de capturar esos actos esporádicos, para una persona ajena a la operación. Ya ha pasado más de mediodía en el hotel. Trabajador6 me llama desde lejos. Alza la mano y pide me acerque. Cruzo nuevamente entre las villas hacia la glorieta y al bajar las escaleras, Mesero1 está escondido entre un pilar del restaurante y la flora que cubre la pared de éste. Con la espalda encorvada cubre la pantalla de su celular, mientras localiza un contacto en su agenda. Llama. Inclino mi celular, ajusto el 
zoom de la cámara y lo coloco en mi oreja como si estuviera llamando. Enfoco a ciegas, y iclick! Mesero1 levanta la mirada hacia las escaleras, se vuelve a verme y le saludo con un ligero movimiento ascendente de cabeza. Igual que lo había hecho Seguridad2 con Trabajador3. Responde al saludo y comenta: “¿También es el látigo? Aguas con Trabajador4, porque luego sales en sus fotos." Afirmo sin decir nada, hago muecas de no poder enlazar la llamada y cuelgo. Bajo al pasillo del Comedor y me encuentro con Trabajador6. "Me toca la guardia, vamos a supervisar que la gente sepa el status del hotel y sus áreas de trabajo. Si tienen una sugerencia o comentario, lo escribes aquí. Ya te hicieron tu identificador, toma. Así no habrá problemas para que te ubique la gente como trabajador de aquí. Dice RRHH que procures no olvidar portarlo siempre que estés aquí." Me coloco la insignia que se ajusta con un imán. "No le pusimos cargo, para que no tengas problema con los demás." Reviso mi celular, abro la galería de fotos y... ¡nada! Sólo palmas, arbustos y la frente borrosa de Mesero1. “¿A qué le quieres tomar foto? ¿Te ayudo?”-"Si quieres tómame foto a mí" Ama de Llaves sale del baño del área de alberca. "Me pongo a la orilla de la alberca, como si estuviera supervisando”. ¡Cick!, otra foto en pose. "Allá abajo están las de Spa, les puedes tomar fotos ahorita que están con su área recién entregada." -"iVamos, sirve que les preguntamos lo de la guardia!" No es la primera vez que Trabajador6 se quedará hasta tarde haciendo la guardia. "No me encanta, pero te da tiempo de terminar algunos pendientes, porque no hay tanto movimiento ni interrupciones telefónicas. Por eso, de una vez adelanto estos formatos de supervisión". Bajando una rampa, la misma estructura de 
madera donde hace un rato Chief contempló la esencia de especias, se encuentra vacía y sin ruidos. “¿Quedó bien bonito, verdad?”

De una sala de masajes, se oye una conversación. Entramos cautelosos y están los trabajadores de Spa sobre la cama de masajes platicando. "¡Quédense así!”, les suplico. "No, ¿cómo cree?, no me gustan las fotos" La lente les apena, la posición de cansancio aún más. Una masajista se levanta espantada y se seca las lágrimas. “¿Estás llorando?”, pregunta Trabajador6. “¡Qué pena! No nos dimos cuenta. ¿Todo bien?" -"Me duele la cabeza solamente [se suena la nariz]. Creo que me voy a resfriar.” -“iAguas, no nos vayas a contagiar tu influenza!” "iAy no, cállate la boca! Si apenas va empezar lo bueno y ya me andas matando." La masajista no lo ha dicho en broma del todo. Realmente hay un miedo serio en sus palabras, como si ya lo hubiera vivido. -"Ve con RRHH, debe tener algo en el botiquín, o en el comedor. Gerente de Spa debe tener también. Sólo por eso te toca la primera pregunta, la más fácil, para que vayas a tomarte algo luego, luego..." Trabajador6 ha sacado una sonrisa a la masajista e inicia su supervisión.

Las interacciones, anteriormente, ya han sido tratadas como el elemento básico de análisis para el estudio de la cultura de un grupo en específico. Tal es el caso de Scheflen (en Winkin, 1984:151) quien desarrolla el concepto de programas como la representación del perfil comportamental ${ }^{32}$ de un individuo.

Bajo este planteamiento referente a las interacciones de las personas, similar a Lefebvre (1991 en Beyes y Steayert, 2011), los programas son compartidos por

${ }^{32}$ Scheflen, interesado en el comportamiento de los individuos y las interacciones, considera que si se pudiera seguir a un individuo de interacción en interacción, podría prepararse un programa describiendo sus roles. Este programa representaría el perfil comportamental. Esto a su vez permitiría comprender un mapa detallado de la cultura de cierto grupo (en Winkin, 1984:151). 
un conjunto de individuos pues pertenecen a una misma concepción cultural. Por ejemplo, el seguimiento dado a las interacciones de Trabajador6 $-\mathrm{u}$ otro trabajador-, permitiría el entendimiento de un grupo más amplio. Nuevamente, se retoma la idea que las concepciones son socializadas y compartidas (Smircich y Stubbart, 1985). De esa misma forma, un programa define la estructura social del grupo, definiendo a su vez, los tipos de participantes que pueden insertarse en éste.

Es decir, el mapa de interacciones entre personas es capaz de filtrar a sus integrantes, de acuerdo a la lógica en la que se desenvuelven. Ya sea por sexo, edad, estatuto social o capacidad (Scheflen en Winkin, 1984:156), los participantes son valorados como aptos o no, de tomar parte en la realización del programa.

Esta selección puede no darse de manera consciente, pero las interacciones entre los participantes requieren de un contexto en común (ya sean valores, gustos o intereses) que se presenten como el vínculo inicial del cual parte su afición por interactuar y mantenerse dentro del programa. No es raro, entonces. Que no tan sólo los trabajadores del Spa no deseen ser fotografiados por alguien ajeno, sino que debido a que la conversación trataba temas ajenos al contexto del observador. Siempre se dirigían a Trabajador6 para explicar su situación. Sólo en el caso de Mesero1, al suponer que coincidíamos en aspectos afectivos, o con Ama de Llaves y Trabjador6 donde la interacción ha permitido encontrar semejanzas más allá de la actividad profesional, la conversación es más 
accesible y por ende la interacción menos coercitiva. Actuamos bajo un mismo programa.

De ahí que "un programa puede reclamar que los participantes mantengan entre ellos relaciones, por ejemplo, que estén emparentados o tengan el mismo nivel social. Generalmente, el programa fijará la naturaleza y el límite de las relaciones durante la ejecución, que estará enmarcada por sistemas de valores, normas y tabúes" (Scheflen en Winkin, 1984:156).

El sistema de valores en la conversación con la masajista, iba más allá de un asunto básico de salud. De acuerdo con las entrevistas realizadas, en VallartaNayarit la influenza AH1N1 marco un punto de cambio para la forma de trabajo. Fue a partir del 2009, año cuando se dieron los brotes en el estado de Jalisco y sucesivamente en Nayarit, que el turismo de la zona tuvo una etapa de congelamiento. El sector hotelero acostumbrado a temporadas altas y bajas, que le permiten pronosticar el comportamiento de sus entradas económicas y por ende administrar sus gastos -principalmente su nómina-, habían estado acostumbrados a una rotación alta de personal temporal que "saltaban" de hotel en hotel sin complicaciones, distribuyéndose de manera "sana" por la zona debido al alto número de vacantes que presentaba la época. La influenza significó menor trabajo, mayor competencia y la rotación frenó.

"Después de la influenza, la temporada alta no alcanzaba para subsanar la temporada baja y los que eramos trabajadores de planta, conocimos por pimera vez los días solidarios. Eso no existía antes de la influenza. Al menos aquí en Nayarit, no. ¿Quién sabe de dónde se lo sacaron? Pero yo creo que surgió aquí en la zona, a causa de la influenza. Pues, antes uno se conocía todos los 
hoteles. Y los hoteles no tenían problema para contratarte o recontratarte. Uno escogía de acuerdo a la temporada que hotel le convenía. Había trabajo para todos" (Ama de Llaves, comunicación personal, 13 de junio 2013).

Estos días de descanso sin goce de sueldo, permitieron reducir la carga salarial de la empresa, y según los empresarios, minimizar el impacto del descanso obligado en la economía familiar de los trabajadores. Los días solidarios se distribuyen durante la temporada baja y ofrecen al trabajador la certeza de continuar con su empleo, aunque de manera intermitente hasta la llegada de la temporada alta.

Es muy común escuchar entre los trabajadores el hacer referencia al "Antes de la influenza" o el "Después de la Influenza", haciendo alusión a un escenario completamente distinto del sector turístico en la zona.

La influenza ha marcado un punto de cambio en la hotelería de la zona, y evoca una transición con gran significado en la manera de percibir la realidad actual y las interacciones entre los trabajadores. El marco es así mismo participante de la designación de roles (Scheflen en Winkin, 1984). De acuerdo al sistema de valores, algunos comportamientos son contemplados como especializados, por lo cual se designan específicas cualidades para la realización de ciertos actos; el género, status y/o profesionalización pueden ser elementos determinantes para la designación del rol (Scheflen en Winkin, 1984).

“AAlguien sabe la respuesta?” Los proveedores de ciertos químicos de limpieza han hecho una reunión de demostración para asesorar en el manejo de los productos, al departamento de Ama de Llaves y al auxiliar de Spa. Mientras tratan las diferencias del uso entre el aromatizante y el limpia pisos, sigo 
buscando la mejor toma para enfocar los diversos sentados de las camaristas y la manera en que RRHH y Ama de Llaves influyen con su presencia en ellas. Algunos notan la presencia de alguien ajeno, otros no. Por ello, se aprovecha la ignorancia de varias camaristas y se logran capturar las primera fotografías infraganti. “¿Nadie?” Ama de Llaves observa a todos, y los invita a participar: “¡No se apenen! Miren que nos andan grabando. Hay que demostrar que sí sabemos." Anonimato desenmascarado. RRHH intenta salvar la situación. "No, no los está evaluando, le pedí tomara unas fotos para el registro de la capacitación." -"Bueno, entonces quién puede decirme ¿por qué no debemos utilizar el aroma para limpiar el piso?" Algunos lo saben, pero nadie levanta la voz. "Porque opaca los pisos", respondo. Las miradas parecen ser de sorpresa. -“¡Así es! Si trapean con aroma, sólo van a opacar el piso y perderá brillo. Por eso nuestros desinfectantes ya tienen un olor suave. Para que de una sensación distinta a la de otros limpia pisos..." Las miradas siguen señalando un gran descubrimiento: El observador sí sabe sobre el trabajo de ellas. ¿Será de hotelería?, ¿será que él también trapeaba pisos?

Había dado el primer paso para ser admitido en la operación, y había sido contundente. A partir de ese momento, el rumor se corrió. Se depositó una confianza en mí, y algunos dejaron de hablarme de usted. Las interacciones se situaron en un programa distinto.

Enfatizar la interacción como punto de arranque en el análisis, permite identificar su participación en la naturaleza del programa y de los contextos, es decir, del espacio en sí. Permite enfocarse en los actos y "revela un panorama más amplio 
de cómo se forman, estabilizan, disuelven y reubican las organizaciones" (Czarniawska, 2012:783).

\subsection{INTERACCIÓN ENTRE TODOS LOS ELEMENTOS}

"No hay una sola manera de entender la ciudad, sino multitud de pequeños relatos que confluyen en espacio y tiempo.

Entre tensiones de la vida contemporánea, la ciudad enfrenta lo violento contra lo superfluo, la realidad y el mito, el presente y el pasado. Fragmentos de la ciudad que se combinan para ser vividos de manera distinta según como nos queramos relacionar y proyectar en ella(...) creando una narración particular de la ciudad.

La multiplicidad de miradas de las obras pone en relieve el carácter de pastiche que puede ser una ciudad. Grandes concentraciones urbanas que, aunque híbridas y confusas, rehacen los significados continuamente y dan lugar a lo cotidiano.

Al día a día".

Carla Prat, "Fragmento" en Colección: 8 Derivas por la Ciudad Liminal, Museo de Arte Contemporáneo Carrillo Gil; D.F., septiembre 2013

V\&S es gestado por la interacción de quienes le viven y por el pulso de los espacios que se desarrollan; donde se cruzan destinos e interpretaciones sobre dirección, sentido e identidad. Sus contradicciones lo evidencian conformado por materia, información y energía: fuerzas indómitas de la naturaleza, del saber positivo humano y subversiones económicas y sociales. 
Un ejemplo de estas dualidades vividas, es la relación que se hace de la hotelería, por parte del público exterior, con un trabajo de atención similar a la de una mujer que es ama de casa. "Eso no es trabajo real, sólo atiendes". Como los de limpieza, limpiar y atender no es trabajo. Lo físico es más animal, y ni siquiera es visto como un esfuerzo mayor, por lo tanto es de un animal débil. Sólo hasta involucrarse de lleno los públicos externos pueden reconocer el esfuerzo físico y mental necesario para llevar a cabo la logística de un día en V\&S. Entonces existe un respeto y consideración a este trabajo. Así se logra una posición estratégica.

A ello se le añade la capacidad de flujo monetario: propinas -a nivel trabajador-, utilidades -a nivel giro-; el trabajador se jacta de su liquidez diaria y el trabajo es aún más respetado, pues permite una independencia económica. Por eso su mayoría es trabajador joven o con familias extensas. Hay una relación del trabajo remunerado con sus expectativas de vida. Un tanto limitadas, en lo que se refiere a proyectos a corto y mediano plazo, fuera del ramo hotelero. Los trabajadores operativos de V\&S se acostumbran a vivir al día.

La familiarización con el personal de V\&S permitió interactuar a partir de distintos roles con las diferentes áreas. Los roles establecidos a partir de las interacciones, dentro de la performación del espacio, ofrecieron una línea de partida en la diferenciación de los espacios, debido a las funciones que realizan.

Así se observó que un espacio es referente y resultado de las interacciones performadas. Se constata que no todas las interacciones son performadas 
dentro de un mismo espacio. Cada espacio contempla ciertas interacciones en su haber, de acuerdo a la lógica que se presume en el determinado programa.

Para su diferenciación, la clasificación de los espacios depende de la naturaleza de su función (Hall, 1972); los espacios en una organización son distinguidos en nuestra mente por la observación de los actos que se desarrollan dentro de ellos. El espacio, visto como un área física, forja en gran medida el comportamiento (Hall, 1972:132). Por lo tanto, la diferenciación de los espacios se acota por la exclusividad de su dinámica y percepción de los trabajadores de V\&S. De pronto, la realidad se leía de distinta forma. Un día laboral corría con la misma rapidez que lo hacía para los trabajadores. Por las mañanas se apresuraba el tiempo entre las múltiples actividades, y después de la comida, los minutos se tomaban su tiempo para mover el segundero, que reposaba en la pila de reportes a completar antes de salir de turno. No así las anécdotas del día. Muchas tenían que esperar al día siguiente, a falta de más horas de tarde y privacidad. La enfermedad no es un pretexto, y la búsqueda del aire acondicionado más cercano, se convierte en la actividad más divertida de la jornada laboral. Y qué decir de los planes para gastar las propinas del día. "Mañana es sábado, pero hay muchos pendientes. ¿Le entras o nos vas a dejar solos?" Siempre se dice que sí, y el lunes hay que asegurarse de publicitar la marca de guerra: "Si el sábado estuvo pesado, no salimos hasta las seis." -“A poco viniste?, ¡no manches!”

El mundo se vuelve el hotel. Y fuera de éste, los trabajadores de V\&S sólo atienden noticias referentes a la situación turística, la inversión en el ramo y los 
posibles frentes fríos. Las amistades, las relaciones afectivas, la familia, el trabajo: todo se vive de distinta manera, según sea temporada alta o temporada baja.

Camaristo1 es el último en salir. Corre detrás de Trabajador4 y más adelante ya está Trabajador1 pasando su huella por el checador. El Bell-boy de la tarde está prendiendo la camioneta con la que regresará a todos al punto de partida. La orilla de la carretera.

Camarista1 y Camarista3 están debajo de la sombra de una pareja de palmeras. En la orilla del estacionamiento y riéndose a carcajadas. Baja del área de construcción una camioneta con batea, donde va personal de mantenimiento y de la constructora. "¿Se van?” Las camaristas se aferran a la orilla de la batea y escalan la camioneta. Dos palmadas al costado de la batea: "iListas!"

Trabajador1 no hace el menor intento de apresurarse para subir a la camioneta, Trabajador8 aún no sale de la recepción y piensa esperarlo.

“iMe dejaron!”, se queja Camaristo1, quien llega cansado por bajar corriendo. "Voy a tener que tomar dos rutas, así no voy a llegar a la quincena". La tarde es más fresca, pero sigue pegando el sol, con gran esplendor. Camarista5 y Trabajador6 siguen atendiendo pendientes de su trabajo de guardia. Los mandos medio aún tardarán en salir tres horas más. Pero la mayoría se van juntos en autos. Por lo cual llegarán a sus casas, casi con una hora y media de diferencia entre los primeros que salen. Para los que llegan, la jornada ni siquiera ha empezado. Aún no olvidan algunos pendientes de sus hogares y piensan en el vaso con agua que beberán tan pronto lleguen a su área de 
trabajo. El Concierge Vespertino, llega corriendo, checa y entra a la recepción. Tarde. Concierge no tiene paciencia para entregarle la bitácora con la información pendiente: "Hoy tienes algunas de las llegadas de los VIP, así que prepárate. Chief anda arriba vuelto loco, así que no te esperes a que regrese para comer. Avísale que baje con tiempo, para que no te quedes esperando".

De pronto, el cielo anuncia una posible lluvia. "Si llueve nos tomamos una chelita en el de siempre, ¿no? Mientras esperamos que se pase.” -“iVale!” Acuerdan Trabajador4 y Camaristo1. Trabajadora4 sale de la caseta principal: "¡Apúrale Bell-boy, que si nos agarra aquí la lluvia, nos vamos a tener que regresar a revisar las villas! Y a mí, hoy sí me esperan en casa." 


\section{CONLCUSIONES}

\section{Extracción: Diario del Investigador}

Al acercarse al final de este trabajo, la lectura pareciera no atreverse a profundizar en las mentes de los empleados, en el origen de los momentos, en el tras bambalinas de la organización.

Pareciera, pero sí lo hace.

El asunto es que el trabajador de V\&S ha logrado asumir los personajes desenvueltos para ocultar el verdadero sentir, que no sólo lo ocupa durante el trabajo, sino frente a cualquier público que considere externo, aún en los momentos ajenos a la operación del hotel.

La verdad del sentir, queda segura -escondida-, cubierta debajo de las sonrisas y las palabras educadas. $\mathrm{Y}$ aunque el gusto por el servicio sea visto como cuestión de vocación, el papel de sumiso va conteniendo palabras, emociones y una que otra acción física que se apetece emitir en contra de aquél que solicita y formula las órdenes. Todo se calla entre los dientes, se presionan fuertemente y se espeta lo contenido, cuando nos dan la espalda.

¿Nos?

Antes de las consideraciones finales, dentro de esta última sección, se busca adentrarse en la percepción del yo, como empleado de servicio en V\&S.

La naturaleza del estudio de caso, impide en cierta medida aventurarse a hacer generalizaciones sobre la dinámica de la cultura hotelera. ¿Es así en todos los hoteles? 
La percepción del trabajador de servicio en la organización, es un constante enfrentamiento de su trabajo con elementos tan personales como el autoestima y el orgullo. En el revisar las habitaciones: secando baños, limpiando espejos; debajo del uniforme, algunos utilizan camisas de colores llamativos. Se les llama la atención y "colores más discretos" se solicitan. ¿Discretos? ¿Acaso se visten estos colores para llamar la atención? Mientras me quito el gafete y me desvisto, en el espejo se refleja mi playera de discreto gris con el parchado de una marca departamental en dorado. Cuando estamos cambiándonos, cuando salimos, la gente observa esa marca en mi playera. Saben que no es una marca cualquiera. $Y$ me siento reivindicado. El trabajador de servicio, que se puso a gatas a levantar algún cabello del suelo del sanitario, ahora lleva una gorra con el bordado de la palomita NIKE. No se trata de llamar la atención, se trata de dirigir la atención. Centrarla en esa pieza de vestir que destaque, más allá de mi personalidad, mi estatus. No por trapear pisos y cocinas, estoy en lo más bajo de los niveles sociales. $\mathrm{Y}$ no sólo es la limpieza, el trabajador de concierge mantiene una ilusión de estar siempre de acuerdo con el huésped. El nivel de estrés es alto con el objetivo de complacer en tiempo y forma. Pero no se compara con la sensación de sometimiento y vulnerabilidad frente a los gritos y quejas. Todo parece ser culpa de uno. La prenda, por muy invisible que parezca, es un recordatorio a los demás. Cuando no la tapa el uniforme, no estoy en hora laboral y soy libre de mis actos; y cuando la cubre el uniforme, es un caparazón. Todo se queda entre el uniforme y mi prenda, pero no traspasa. La cadena de oro, la pulsera que me regaló el novio, mi ropa interior favorita; no son para ir en 
contra de la discreción y la neutralidad del espacio, son un escudo. El performance sumiso, siempre educado y alegre, llega hasta ahí. Ahí se canaliza, se absorbe, se contiene y de ahí se desfoga cuando el personaje de actitud de servicio sale del escenario y se relaja.

La organización tiene sus propias prendas, esos escudos que impermeabilizan. La posición de servicio, de acuerdo a lo observado en este estudio de caso, es embestida de constantes órdenes y represiones. Los trabajadores se escudan en el anonimato de su logística. La operación es desconocida para los que no forman parte del séquito. Si no se sabe cómo es, no se puede juzgar. El respeto a lo difuso de la operación, se demuestra en sus múltiples filtros para ceder información a sus mismos compañeros de trabajo y en su necesidad de externar lo agotado de su día, sin detenerse en los detalles.

Tomo mi celular, me dispongo a comer y escribo un mensaje: "Tres horas más y termino... mucho por hacer aún. Todo bien, sólo cansado. Provecho." La comida cae revitalizante, y más aún, porque me la merezco. En ese mensaje de texto no hay especificaciones del día, ni siquiera la mención que todo ha sido trabajo en equipo. Para los demás que no están dentro de la operación, el día ha estado bajo mi responsabilidad, el sol se ha posado específicamente sobre mi espalda y no hay manera en que alguien pueda entender el nivel de cansancio y compromiso que descansa en mí. No soy el único compartiendo su día con los demás. Y estoy seguro que no están contando la misma historia, o mejor dicho, es la misma obra, distinto protagonista. 


\section{Consideraciones Finales}

En este último apartado, se presenta una serie de consideraciones finales que resaltan la dirección de los hallazgos manifestados en el presente trabajo.

Como se plantea en un inicio, la línea exploratoria del trabajo se propone bajar a un estudio de caso, la conceptualización realizada por Beyes y Steyaert (2011) del Spacing Organization.

Atendiendo a la cultura como la perspectiva de los Estudios Organizacionales, sobre la cual descansa este estudio. El análisis se centra en el despliegue de aquellos elementos que visten y conforman el concepto performativo de espacio. A partir de una previa categorización de estos elementos, se presume al hotel, como un constructo complejo que representa una pequeña parte de la vida social; Enfatizando la subjetividad contenida en la interpretación de los trabajadores dentro de esta organización.

La profundización en estos elementos despierta un panorama amplio que podría no ser tan fácil de describir en un estudio de campo como éste -no mayor a tres meses-. Sin embargo, de acuerdo a la cantidad considerable de elementos participantes encontrados en la dinámica del hotel, se asume una postura inclinada positivamente hacia la trascendencia de investigaciones de esta naturaleza.

Los anteriores hallazgos se presentan bajo la consideración de evidenciar un pequeño fragmento de la realidad vivida en la hotelería. Claramente existe un acentuado reconocimiento de aquellos elementos que resaltan positivamente el trabajo de los empleados de V\&S, pero fiel a la metodología seleccionada, nos 
respaldamos en esta subjetividad validada por Riessman (2002 en Biglia y Bonet, 2009), donde el observador como narrador vital, hace consciencia de su presencia y las incidencias que puede llegar a tener en las interacciones que perfoman a los mismos espacios. La preferencia de estos elementos se identifica en la mayoría de evidencias de las sonrisas esbozadas por los trabajadores, en comparación con los momentos de agobio, frustración, malestar y condiciones de trabajo precario también participes en la performación del espacio, y en los cuales no se detuvo con el mismo hincapié.

En parte, esta evidente inclinación comprueba una vez más, la capacidad que tienen los trabajadores de V\&S para mantener la escena de sus personajes frente al público externo; y por otra parte, refleja el asombro del investigador al observar esta capacidad de subordinar los propios sentimientos a la incorporación de un personaje afable y centrado, nublando la existencia de aquellos puntos antónimos.

El performance de los trabajadores de V\&S es presentado en el caso, bajo pequeñas escenas separadas, que describen los actos enfatizados por sus personajes, para lograr determinada reacción; sin embargo deben ser entendidas como unísonas. Todas las escenas están presentes al mismo momento en el hotel, y su totalidad representa la foto de un hotel en determinado momento, mas no como un retrato absoluto. Se descubre al espacio como un concepto dual de percepción y construcción continua, cada trabajador percibe diferente y su sensibilidad está orientada a particulares intereses (Hatch, 1993), y a las interpretaciones compartidas (Smircich y 
Stubbart (1985:727).

La propuesta de categorización y enlistado de elementos para operacionalizar los supuestos teóricos de Beyes y Steyaert (2011) y Czarniawska (2004), principalmente, son sólo eso, una propuesta que logró dar sentido -estructura- al análisis del espacio performativo, bajo una lente integral, ligada a la representación de la cotidianeidad lo más apegado posible, por ello se rescatan tres momentos importantes dentro del trabajo, que ambicionan dar este sentido ecléctico a la investigación: la descripción e interpretación sensorial de V\&S performance de la narración-, la observación de las prácticas sociales performance de los trabajadores-, y la concientización de la presencia del investigador -performance del narrador-; todo ello cubre el enfoque performativo que permitió apreciar y recolectar la manera en que el espacio se va performando con las interacciones de los objetos, el área física, las personas y el ambiente, similar a la forma que se presenta en la realidad. Contrario a la descripción lineal de los hechos que se maneja comúnmente, en la presentación de un caso.

En general se reconocen las bondades del uso de un concepto performativo como el spacing para tratar asuntos culturales dentro de una organización Sin embargo, la limitante de admitirse como una sola narración, de las múltiples posibles, coarta la posibilidad de suponer alguna generalidad dentro de las interacciones observadas. Ello no imposibilita la oportunidad de discernir impresiones generales sobre lo que se considera debe ser el rol absoluto de un trabajador. 
Bajo la misma línea, el espacio performativo aporta un enfoque oportuno a tratarse - y a profundizar en un siguiente trabajo- en la apropiación del espacio. Elementos como los actos de habla y la teatralidad del performance, fijan una relación entre lo que se dice y las sensaciones de dominio -territorialidad- de los personajes de los trabajadores, promoviendo vínculos más cercanos -confianzay la apropiación de los espacios.

La administración del tiempo: momentos de trabajo paralelos al no-trabajo, se derivan de la confianza de las relaciones estrechadas. Hay una familiaridad inserta en los espacios donde se permiten los trabajadores compartir más allá de lo estrictamente operativo.

Se observa un manejo del anonimato, al difuminar las operaciones ajenas a ciertos públicos, como cuando se conversan hechos que no pueden ser comprobados por otros departamentos, y que, o bien no son ciertos o son exagerados, enfatizando lo bueno y omitiendo lo malo. La sensación de anonimato aleja, así mismo, al trabajador de sus públicos. Se establece una distancia frente al huésped, el jefe o algún compañero de otro departamento. La forma más evidente es retirando el nombre y agruparlos en departamentos: los de mantenimiento, los de arriba, los de oficinas, los que no son de hotelería; Se realiza un extrañamiento, que permite sacarlos de tu vida personal. La distancia permite verlos y hablar de ellos de manera diferente. Se perciben como ellos, no nosotros. No es lo mismo decir Jorge y Raúl, a decir los de mantenimiento. Mismo mecanismo que se ocupa con el huésped. Sólo se dirigen a él con su nombre, en la interacción cara a cara, fuera de ese espacio, deja de tener una 
identidad. Todos son iguales: exigentes, necios, demandantes, y la lista sigue. El extrañamiento despersonaliza, y permite canalizar las diversas sensaciones (reacción de las interacciones con los públicos) de forma más ordenada y clara. Jorge es muy hábil, pero en sí, los de mantenimiento son bárbaros, sin modales. Hay que saber hablarles.

Para concluir, como comentario al margen, y una prueba más de esta presión por mantener detrás del telón las ambiciones de sus personajes secundarios (entendiendo que la lógica hotelera es la que consideran principal, como se percibe en el caso), se deja asentado la solicitud, por parte de un trabajador del hotel, de realizar una versión censurada del trabajo, para la entrega última. Debido a que varios detalles -aún reiterando que este trabajo hace mayor énfasis en puntos "positivos" de la operación de V\&S-, eran vistos como incriminatorios y mal vistos -o de mal gusto- para publicarse sin consideración en la edición final.

Más allá de las causas, la consecuencia es una narración ligera -o al menos esa es la intención- que permita al lector sumergirse en uno de los puntos más caóticos de la conceptualización del espacio performativo: el dinamismo.

Buscando hacer un análisis de la formación del espacio en una empresa, el estudio de caso en el hotel V\&S dirigió la investigación a abundar en los conceptos performativos para explicar la continuidad encontrada, en los actos e interacciones, de los distintos momentos de los trabajadores dentro de sus áreas de trabajo. El enfoque alcanzado, conduce al reconocimiento de una 
multiplicidad de espacios, dentro de una misma empresa, causa de un momento anterior y consecuencia de un momento futuro, en la dinámica del hotel. La ideología, las interacciones, las sensaciones se perciben evolutivas, como se presupuso. La serie de reinterpretaciones por parte de los trabajadores, a primera vista, se identifican mas parecidas a saltos cuánticos entre personajes de un mismo trabajador, que a una cadena ascendente o descendente de significados. Sin embargo, en una segunda lectura, se logra percibir este sentido sperberiano al que aluden Montaño y Rendón (2000), como causa y consecuencia de una red de reapropiaciones semánticas situadas dentro de un contexto más amplio que la esfera laboral de los trabajadores. De ahí, que se haya buscado explicar este fenómeno, a partir de la latencia de los personajes, incorporados en el trabajador de V\&S: cada espacio, diferente en cierta medida de los otros, se involucra con los demás de manera continua y paralela, en el sentido que están presentes en un mismo momento y mantienen una interacción a partir de los actos presentes de los individuos. Algunos son vividos con mayor énfasis en determinados momentos, a partir de los públicos con los que se interactúa, pero ninguno es suprimido en su totalidad.

\section{¿Así será en otras organizaciones?}

El espacio performativo ha permitido situarnos en la particularidad de la organización para enfrentarnos de manera más fiel a la dinámica del hotel. Esta perspectiva no sólo alcanza a desentrañar las actividades detrás de los clientes en empresas del sector servicio. El espacio performativo, y el enfoque de los conceptos que se ligan a él, nutren al supuesto de que cada organización es 
única, diferente y compleja; pero a su vez, enfatiza en la importancia de analizar a la colectividad de las organizaciones bajo líneas de investigación más inclusivas y dinámicas como ésta. Se deja atrás un enfoque individualista, y se sitúa en el todo. Donde el performar rompe con el actor organizacional racional como centro de una empresa y lo coloca modestamente al nivel de otros múltiples elementos (actitudes, áreas físicas, temas de conversación) como parte integral dentro de un todo holístico. El enfoque positivista de la organización diseccionada (la cual puede ser estudiada por partes), deja de lado la importancia de la dinámica del momento presente. Ahí la importancia de este trabajo: la organización no es plana, aún desmembrada sigue siendo un cúmulo de interacciones que no pueden ser desconectadas. No es sólo descrita, la organización se mueve, está viva. 


\section{BIBLIOGRAFÍA}

Anand, N., \& R. Daft (2007). "What is the right organizations design?" Organizational Dynamics, Vol. 36, NO. 4, pp. 329-344

Arellano, D., \& E. Cabrero (2000). Reformando al gobierno una visión organizacional del cambio gubernamental, Miguel Angel Porrua, pp. 78-94

Austin, J. L. (1962). How to Do Things with Words. Edited by J.O. Urmson. Oxford: Clarendon.

Bateson, G. (1982). La nueva comunicación. Ed. Kairós Psicología. Barcelona.

Beyes, T., \& C. Steyaert (2011) 'Spacing organization: non-representational theory and performing organizational space', Organization, 19, pp. 45-61.

Biglia, B., \& J. Bonet (2009). La construcción de narrativas como método de investigación psico-social. Prácticas de escritura compartida. FORUM: QUALITATIVESOCIAL RESEARCHSOZIALFORSCHUNG, Volumen 10, No. 1, Art. 8.

Clarke, T., \& S. Clegg (1998). Changing Paradigms. The Transformation of Management Knowledge for the $21^{\text {st }}$ Century, Harper Collins Business, London. 
Czarniawska, B. (2004). "On Time, Space, and Action Nets." Organization 11(6). London: Sage Publications.

Czarniawska, B. (2004). Narratives in Social Science Research. Introducing Qualitative. Methods. London: Sage Publications.

De la Garza, E. (2010). "Hacia un concepto ampliado del trabajo. Del concepto clásico al no clásico." España. UAM-Iztapalapa y Anthropos Editorial. Capítulo I ¿hacia dónde va el trabajo humano? pp. 21-36

Fernández, V., \& R. Urdain (2004). Publicidad. México D.F., Thomson

Goffman, E (1959). The Presentation of Self in Everyday Life. New York: Doubleday. Anchor.

Hall, E. T. (1972). La dimensión oculta, Madrid, Siglo XXI.

Hall, E. T. (1973). The Silent Language, Anchor

Hatch, M. (1993), "The Dynamics of Organizational Culture." The Academy of Management Review 18, No. 4 pp. 657-693 
Hatch, M. (1997), Organization Theory. Modern, symbolic, and postmodern perspectives, Oxford University Press. E.U.A

Hornillo, M.E., \& J.L. Sarasola (2003). "El interés emergente por la narrativa como método en el ambito socio-educativo: el caso de las historias de vida." Portularia: Revista de Trabajo Social. Vol.3 pp. 373-382

Joseph, I. (1988). El transeúnte y el espacio público: Ensayo sobre la dispersión espacio público. Gedisa Editorial

Markovska, J. (2008) Performance and Modernity. VDM Verlag Dr. Mueller e.K.

Mintzberg, H. (1992) El poder en la organización, Ariel, Barcelona. Pp. 1-8, 2434, 37-53 (Capítulos 1,3,4).

Montaño, L. (2001). "Nuevas relaciones humanas: un falso reto a la democracia" en Colección Cuadernos Universitarios, UAM

Montaño, L., \& M. Rendón (2000). "La noción de organización. Sentido, polisemia y construcción social." Iztapalapa 48 La administración frente a los desafíos del cambio social. UAM, enero - junio, México, pp. 63-84. 
Munné, F. (1980). Psicología del Tiempo Libre: Un enfoque crítico. Universidad Estatal de Pensilvania, Trillas.

Neffa, J. C. (2010). "La transición desde los verdaderos empleos al trabajo precario" en De la Garza, Enrique y Neffa, Julio César (coords.) Trabajo, identidad y acción colectiva, México, UAM-Iztapalapa, Clacso y Plaza y Valdés S.A. de C.V. pp. $43-80$

Palencia-Lefler, M. (2008). 90 Técnicas de relaciones públicas. Barcelona, Bresca Editorial.

Rabotnikof, N. (1997), El Espacio Público y la Democracia Moderna, Ed. IFE, México.

Scott, W.R. (1981). Organizations: rational, natural and open systems. Englewoo d Cliff, NJ: Prentice-Hall.

Searle, J. (1969). Speech acts, The MIT Press, Cambridge, Ma.

Searle, J. (1975). Indirect Speech Acts. In P. Cole \& J. Morgan (eds.) Syntax \& Semantics. Vol. 3: Speech Acts. New York: Academic Press pp 59-82. 
Smircich, L. (1983). "Concepts of Culture and Organizational Analysis." Administrative Science Quarterly, 28(3): pp. 339-358.

Smircich, L., \& Ch. Stubbart (1985). "Strategic management in an enacted world". Academy of Management Review 10.

Tellis, W. (1997, July). "Introduction to case study"'. The Qualitative Report

Tellis, W. (1997, September). "Application of a case study methodology". The Qualitative Report

Velarde, M. (2003), Modelo Organizacional y estrategias de Calidad en los servicios. El caso de una organización hotelera, tesis de doctorado en la Universidad Autónoma Metropolitana, Iztapalapa, México.

Winkin, Y. (1984). La nueva comunicación. - Gregory Bateson - Albert E. Scheflen - Ray L. Birdwhistell - Edward T. Hall - Don D. Jackson - Paul Watzlawick - Stuart J. Sigman - Erwing Goffman (eds). Editions du Seuil , Points, Anthropologie, Sciences humaines.

Yin, R. K. (1994), Case Study Research, SAGE publications. 


\section{Sitios en Internet.}

$\wp$ NoticiasPV.COM (19 de marzo de 2010). Bahía con Horario central a partir del 4 de Abril. Recuperado el 02 de septiembre de 2013, de http://www.noticiaspv.com/bahia-con-horario-central-a-partir-del-4-de-abril/

$\wp$ JALISCO Gobierno del Estado (31 de mayo de 2013). Presentación del Programa Integral de Promoción Internacional Vallarta-Nyarit.

Recuperado el 03 de junio de 2013, de http://www.jalisco.gob.mx/es/prensa/discursos/4820

$\wp$ 3SBIZKAIA.ORG (Julio 2012). Contruyendo vínculos en las organizaciones. Generando transformación social. Recuperado el 14 de marzo de 2014, de http://www.3sbizkaia.org/Archivos/Documentos/Enlaces/1295_201207OTS-uztaila.pdf

$\wp$ CLUB DES PLUS BELLES BAIES DU MONDE (s/f). Baie de Banderas. Recuperado el 28 de julio de 2013, de http://www.world-bays.com/fr/baiede-banderas-47-47.html 
ANALISIS DEL ESPACIO

PERFORMATIVO EN UNA EMPRESSA HOTELERA
En México, D.F., se presentaron a las 9:00 horas del día 29 del mes de mayo del año 2014 en la Unidad Iztapalapa de la Universidad Autónoma Metropolitana, los suscritos miembros del jurado:

DR. ADOLFO MIR ARAUJO

DRA. MARIA TERESA MAGALLON DIEZ

DR. JORGE ANTONIO SANCHEZ GALVAN

Bajo la Presidencia del primero y con carácter de Secretario el último, se reunieron para proceder al Examen de Grado cuya denominación aparece al margen, para la obtencion del grado de:

MAESTRO EN ESTUDIOS ORGANIZACIONALES

DE: MIGUEL ANGEL CASTILLO PEREZ

$y$ de acuerdo con el articulo 78 fraccion III del Reglamento de Estudios Superiores de la Universidad Autónoma Metropolitana, los miembros del jurado resolvieron:

\section{APROBAR}

Acto continuo, el presidente del jurado comunic6 al interesado el resultado de la evaluación $y$, en caso aprobatorio, le fue tomada la protesta.

LIC. JULIO CESAR, DE LARA ISASSI DIRECTOR DE SISYEMAS ESCOLARES J

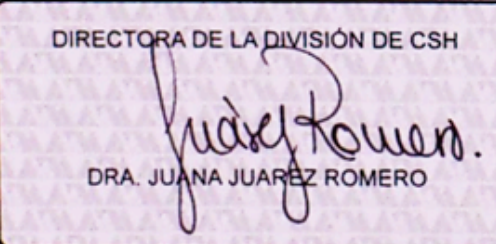

VOCAL

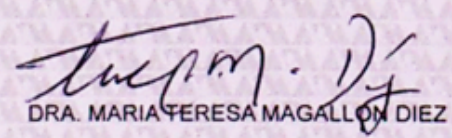

PRESIDENTE

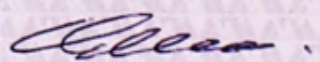

DR. ADOLFO MIR ARAUJO

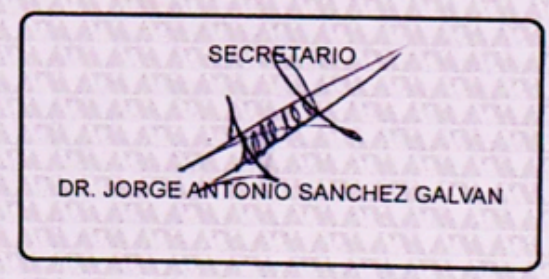

